\title{
معالم التّقد الأدبي ومبادئه عند محمد البشير الإبراهيمي
}

\section{Literary criticism and its principles of M.A. Al-ibrahimi}

\section{Dr. Rabah Benkhouya 1 د. رابح بن خوية}

كلمات مفتاحية: النقد الأدبي، النقد الإسلامي، النقد الأدبي الإسلامي، التصور الإسلامي للأدب، نصوص أدبية، محد

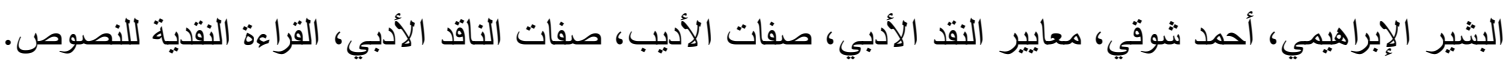

سنتطرق في هذا البحث إلى بعض الإسهامات النقدية لمحد البشير الإبراهيميّ على الصنّعِد الأَدَبِيّ والتَّقديّ لتطوير

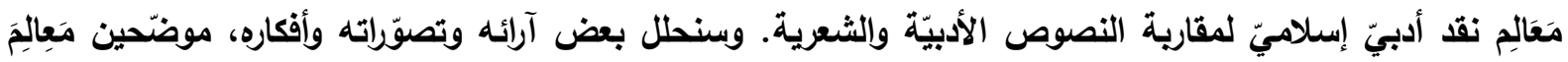

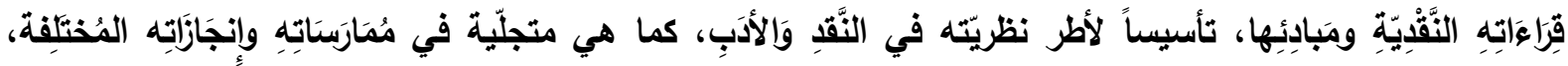

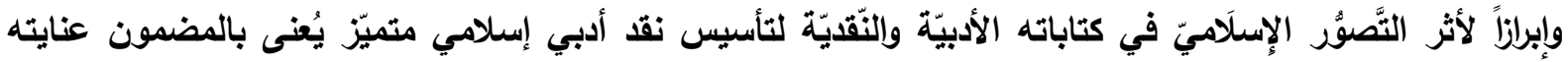

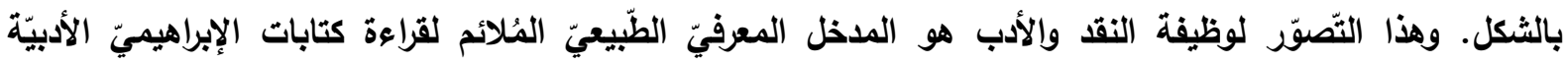

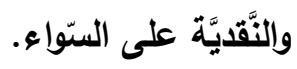

(1

عرَف القُرّاء والمهتمون بالثأن الأدبي في العالم العربيّ والإسلاميّ الإمام محمد البشير الإبراهيمي (1889-1965) -رحمه الله- كعالم مصلح و مربٍ وداعيّة من أبرز رجالات جمعيّة العلماء، ورجل وطنيّ من الطراز الأول، متسماً بكثير من الأوصاف والنّعوت، التي تتجلى من خلال دراسة أعماله وآثاره وتحدّد جوانب كثيرة مهمّة في شتخصيّته العبقريّة الفذة. ومع تلك العناية المؤكدة به، فقد قلّ ونَدرُ، في أحاديث القرّاء كما في كتاباتهم، أن يتعاملوا مع الإبراهيميّ ناقداً وأديباً ولغويًّا، ويتأمّلوا في آثاره بوصفه صاحب نظرات نافذة، وممارسات قيّمة في الأدب، شعراً ونثراً ونقداً وتاريخاً، تقيماً وتقويماً، وفي اللّغة تحقيقاً وتأصيلاً. والحقيقة أنّ ذلك الثّامّل العلميّ المأمول في آثار الإبراهيميّ الأدبيّة يستغرق وقتاً ويستأهل جهداً

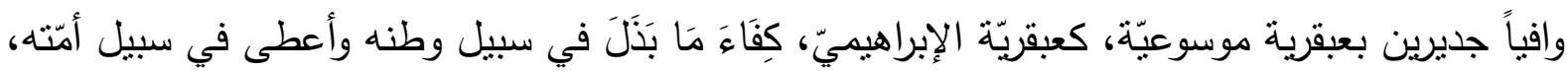

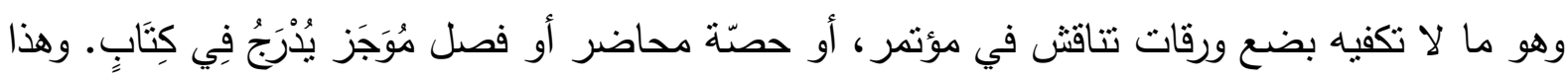
1. د. رابح بن خوية، جامعة محمد البشير الإبراهيمي، برج بوعريريج، الجزائر ، بريد إلكتروني: ra.benkhouya@yahoo.com 
لا يَحُولُ دون نَّاؤلٍ علميّ لإنجازاته النّقية وملاحظة لأهمّ معالم نقده الأدبيّ من المنظور الإسلاميّ.

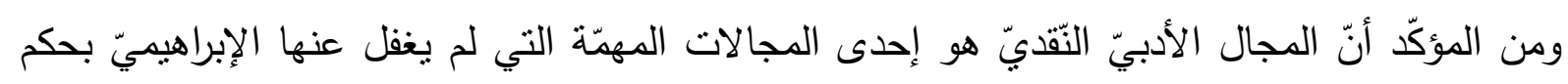

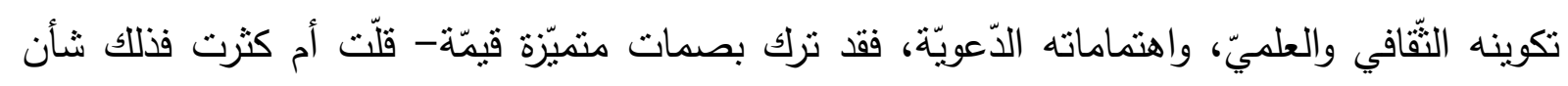

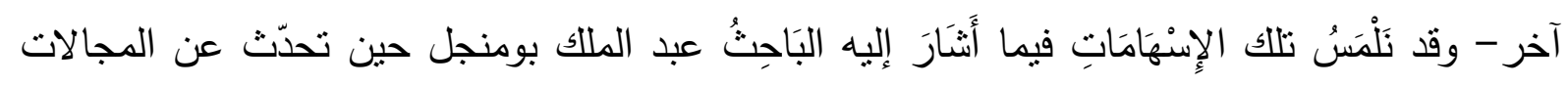

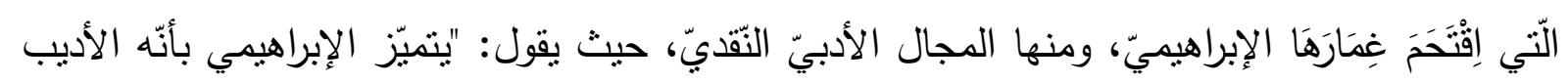

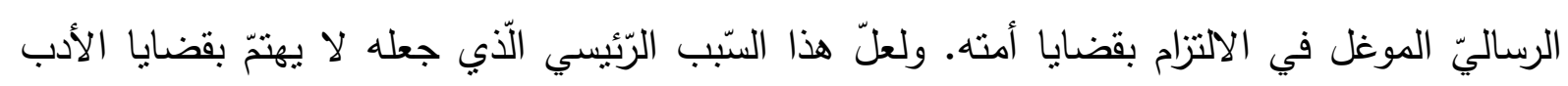

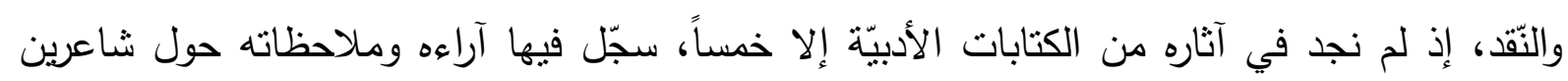
إسلاميين معاصرين له، حبييين إلى قلبه، وهما شاعر الثُمال الإفريقي محمد العيد آل خليفة، كما يلقّبه

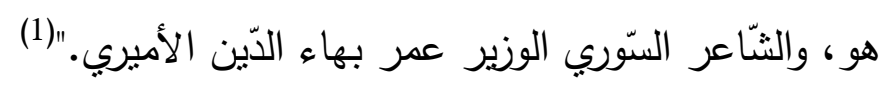

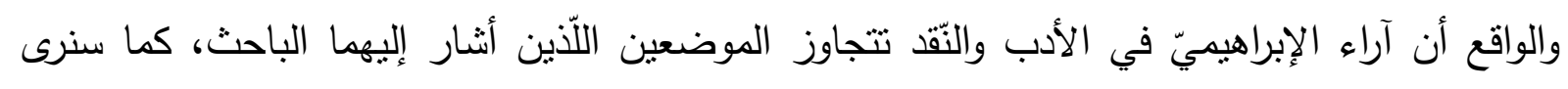

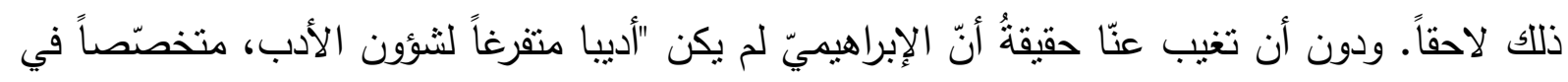

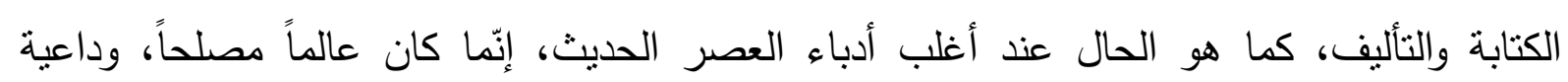

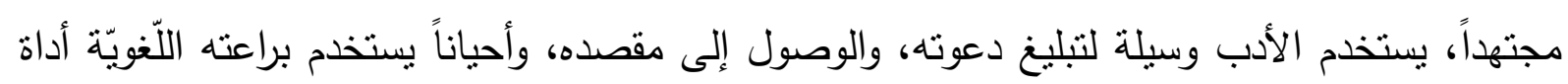

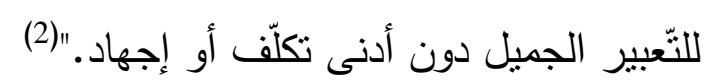

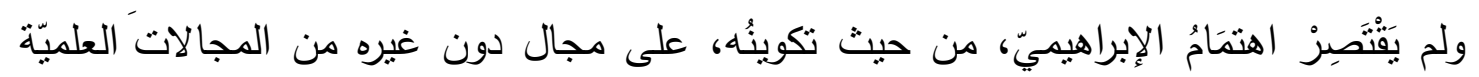

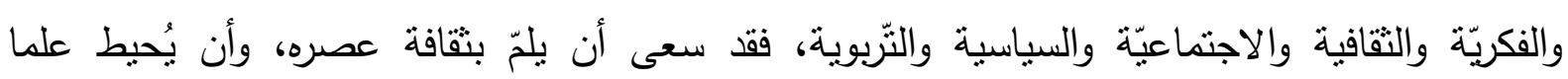

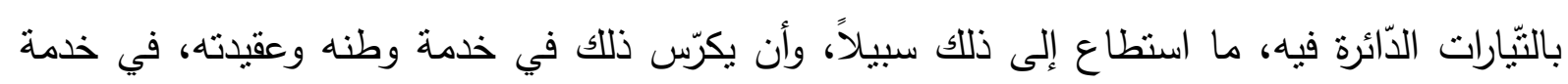
الجزائر الوطن المستلب المغتصب والإسلام الدّين المستهدف المحارب. ولعلّ المسؤوليّة الجليلة التي فئي

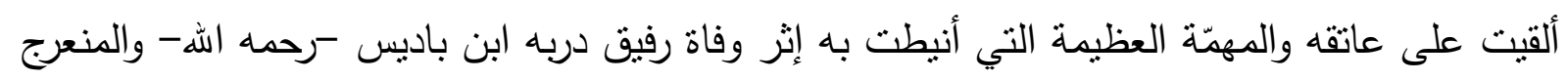

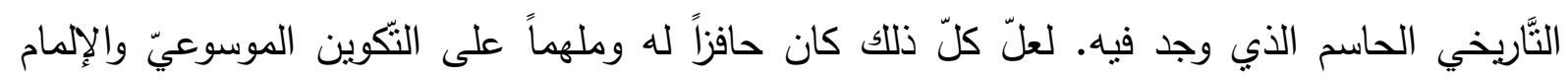

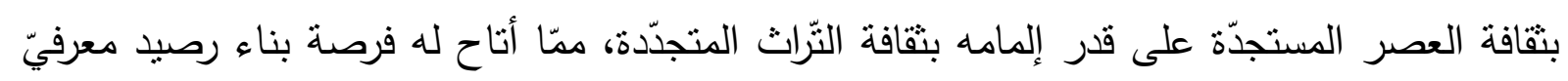
شاسع، وهو ما يتجلّى في آثاره المتعددة وفي أقوال من عرفه ولقيه.

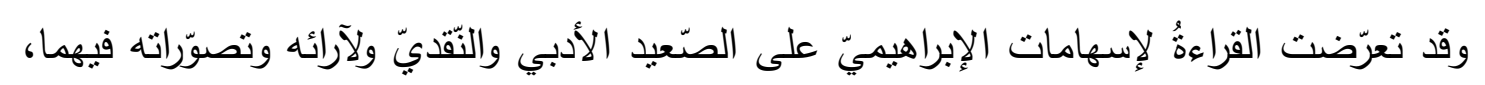

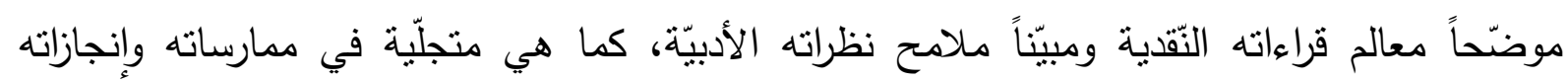

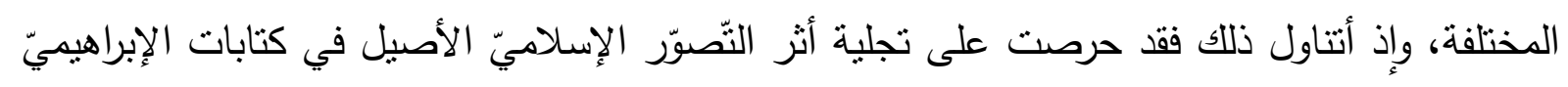

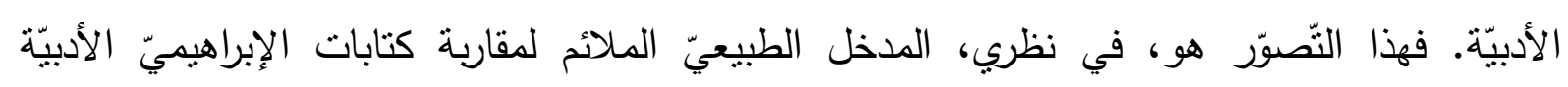

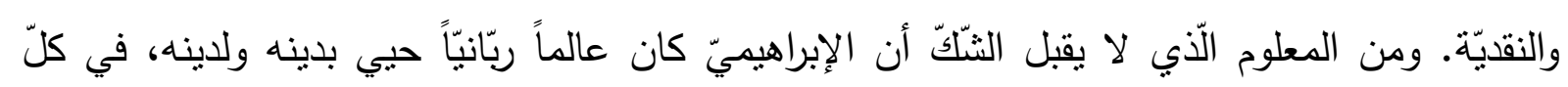

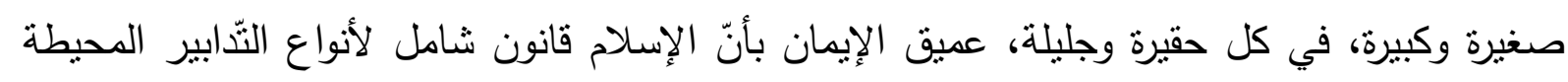

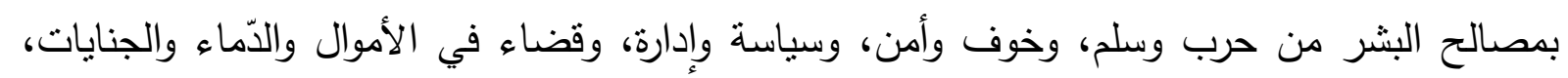


وفي بناء الأسرة(3). وراسخخ اليقين بأنّ "أصلح نظام لقيادة العالم الإنساني هو الإسلام"(4). وأنّ دواء العالم

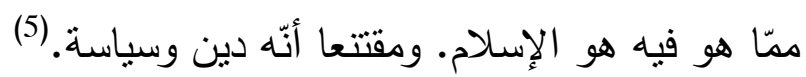

\section{وفي ضوء ما سبق، فسأقف في هذه القراءة على المحورين التاليين:}

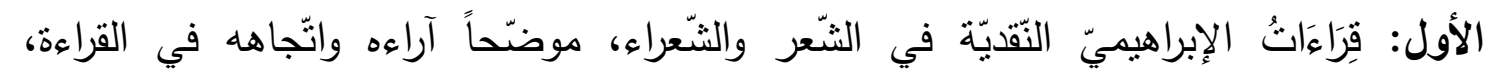
ومستجليّاً أثز التّصوّر الإسلامي في تلإلك القراءة، ومبيّناً سعة نقافة وعمق معرفة الإبراهيميّ الأدبيّة

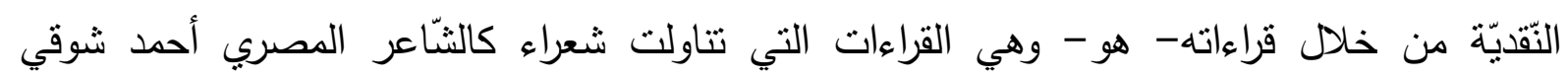

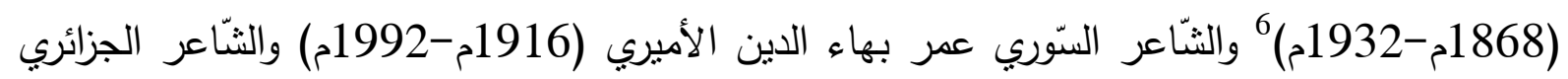
محمد العيد آل خليفة (1904م-1979م).

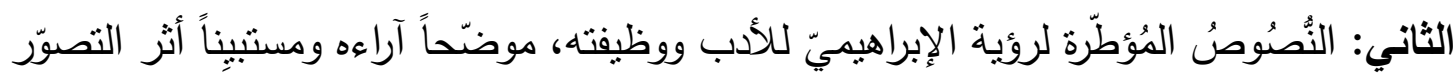
الإسلامي في نظراته الأدبيّة.

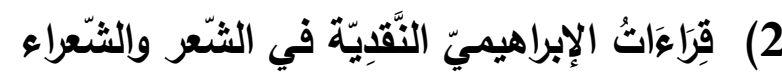
يتجسّد الوعي النقديّ لدى الإبراهيمي عبر النماذج المقترحة النتالية:

2.12

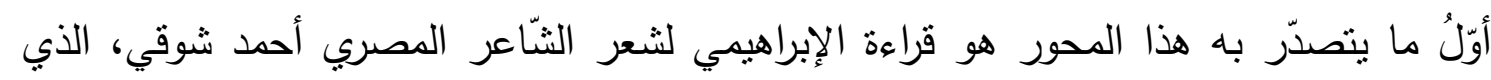

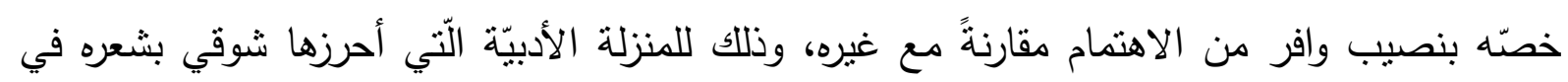

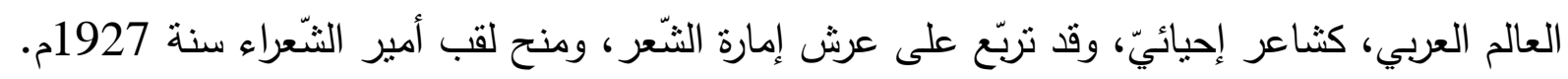

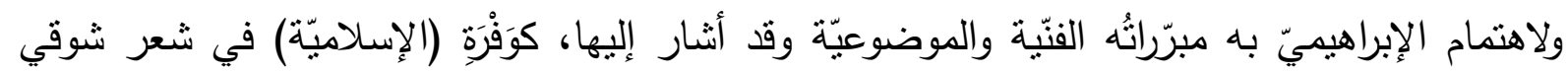

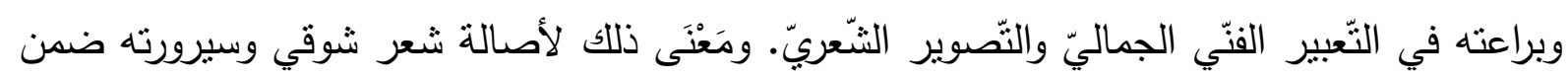

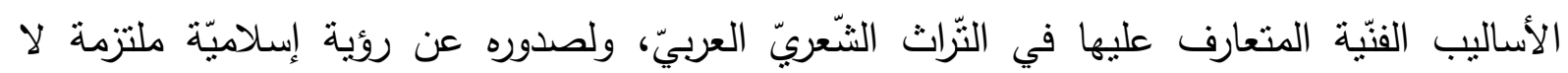
تخطئها القراءة المتأنيّة في سائر شعره وشعره المجدّد. وستكون متابعتا لقراءة الإبراهيميّ وفق معايير مستخلصة من القراءة ذاتها، وهيرة وهي:

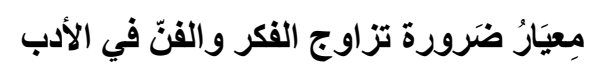

يمكن القول إنّ الإبراهيمي، في قراءته لشوقي، كان متأثّراً بنزعة المحافظة، وآراؤه وأحكامه

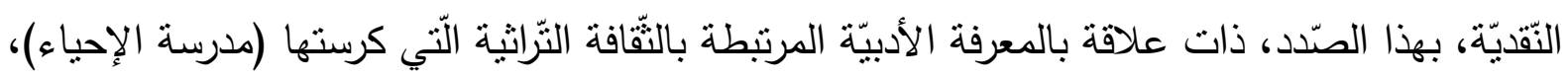

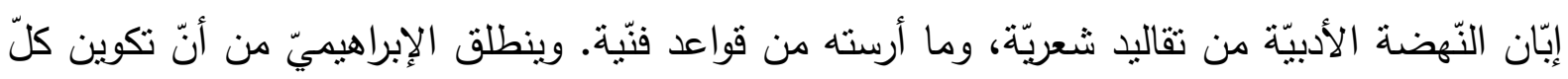

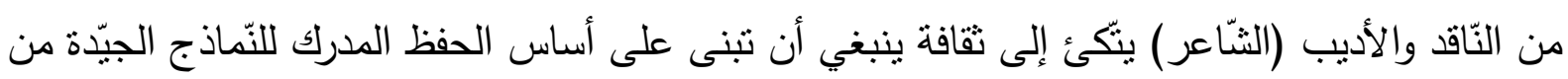

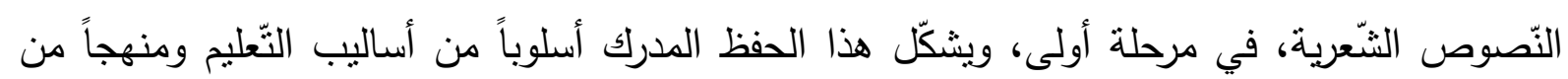




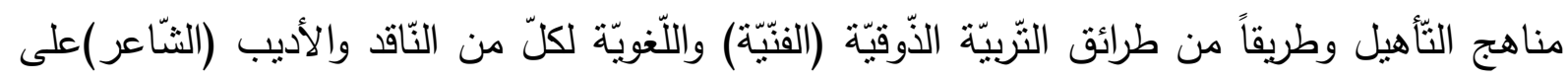

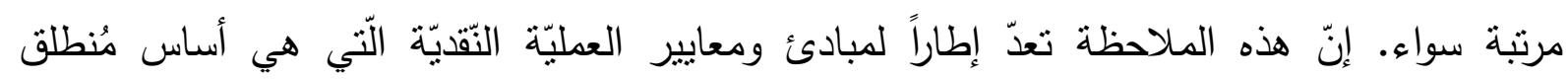

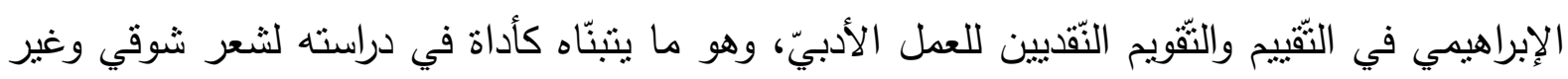

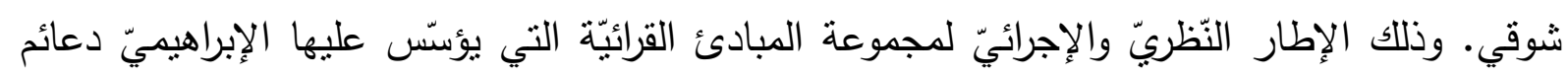

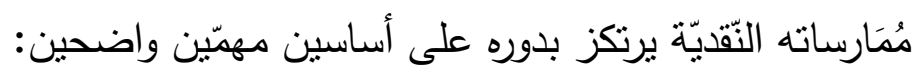

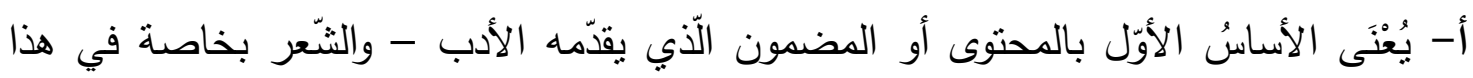

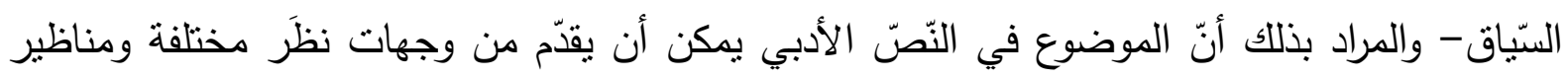

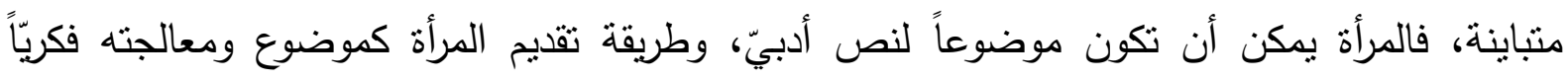

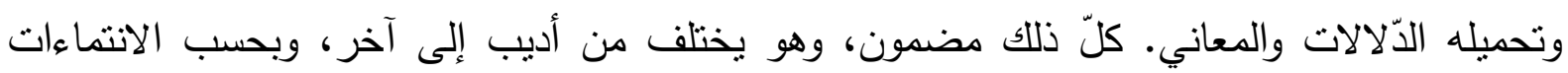

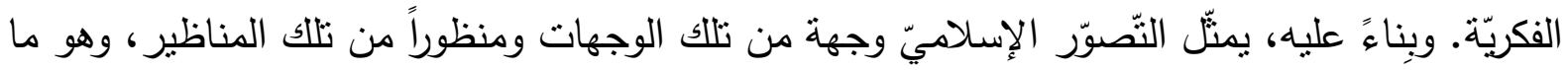

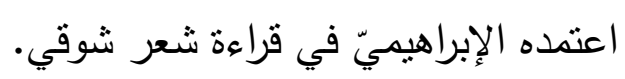

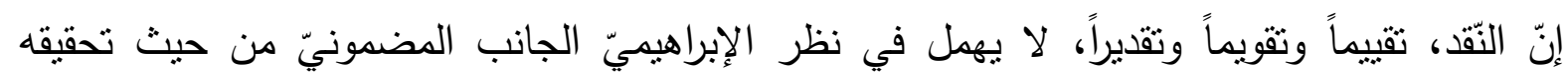

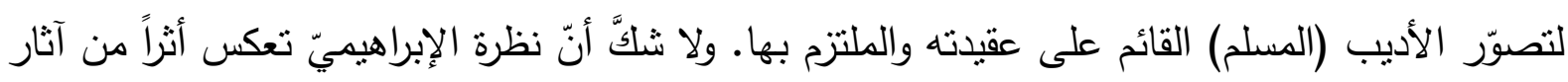

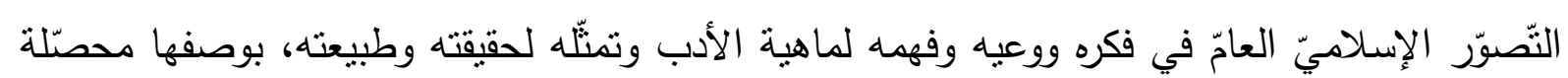
للمضمون والثنّكل أو للفكر والفنّ.

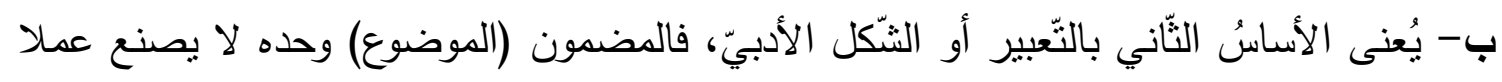

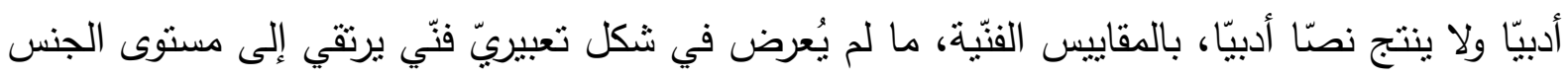

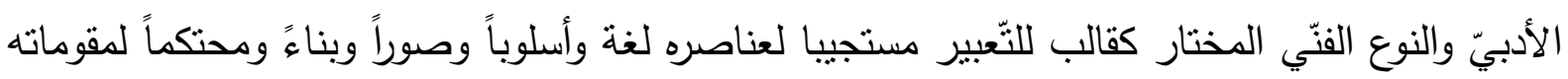
المؤثنّة له.

وهي الحقيقة التّي كانت قائمة في وعي الإبراهيميّ، فلم يتتاس الذّرر الخطير الذي تتهض به لغةُ

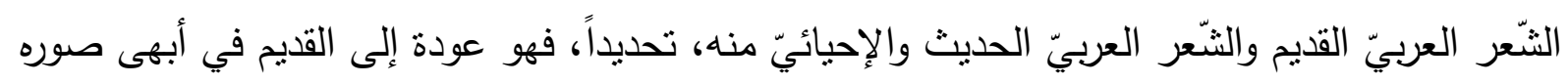
وامتداد له وذللك ما يُستتبط من دراسة الإبراهيمي للثنّعر وتوجيهه للثنّعراء.

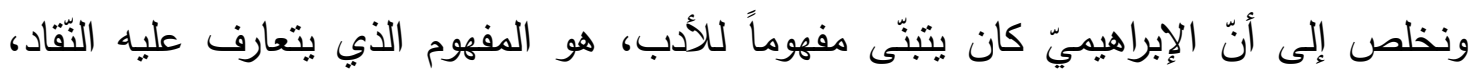

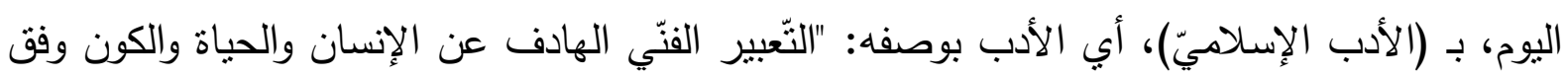

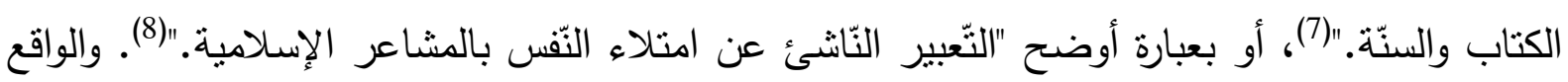

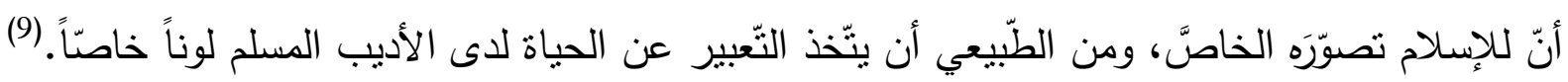

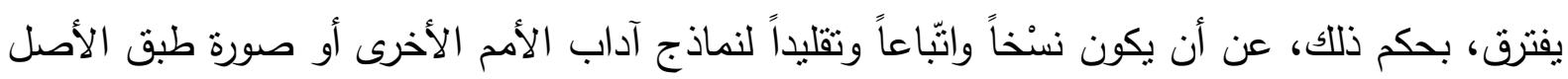
لها.

ومن هُنَا، مِن هذا الوعيّ النقديّ يخصّ الإبراهيمي شعر أحمد شوقي بالتّقدير الكبير والإعجاب

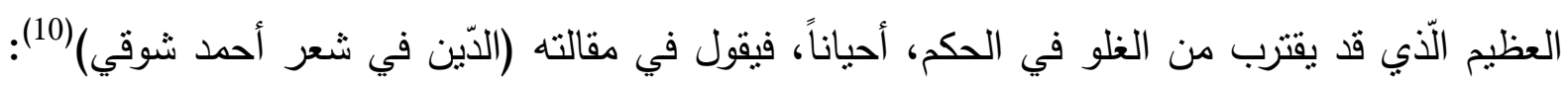


"إنّ لثوفي عليّ لحقّا أوجبته على نفسي حين غاليت بقيمته في شعراء العربيّة غابرهم وحاضرهم."(11) ففي هذه المقالة، يقدّم الإبراهيميّ نظرة ثاقبة بعيدة الأثز تثّسم بالعمق والثّّمول والتّسامح والإنصاف والأخلاقيّة والإنسانيّة، فيوافق شوقي فيما يُعرِب عنه، شعراً، من آراء، كرأيه في (الدّين)، فالدّين في شعر بإِي شوقي أعمّ من (الإسلام)، فيوافقه في ذلك ولا ينكره عليه، حين قول: "فثوقي تغنى بكل دين استحدث خلقا أو ثنّب فضيلة إنسانيّة أو زرع محبّة بين الناس، أو أنشأ حضارة أو زاد فيها أو ولّد فناً، أو كان إرهاصاً بدين أكمل..."(12) وفي هذا السيّاق، لا يخفى ما يوليه الإبراهيمي للثّعر الذي يحفل بالقيم ويشيد بالأخلاق وينوّه بالفضائل من أهميّة. مِعْيَرُ التَّعاطف تُجْاه الأديب

يؤكّد الإبراهيمي على معيار مهم كثيراً ما أثنار إلبه نقاد العصر الحديث في التعامل مع الأدباء وأعمالهم، وهو (التّعاطف). وهو معيار يمكّن من ملاحظة العمل باعتدال وحياديّة والاقتراب منه دون أحكام مسبقة، فينبغي على النّاقد والقارئ أن يضع في حسابه ومن بين أدواته هذا المعيار في تعامله مع الأديب وتتاوله لنصوصه. ولماذا التّعاطف مع الأديب ومع النّص؟ لأنّ كلّ من النّاقد والأديب بشر .. وعمل النّاقد يكمن في تقييم وتقويم تجربة إنسانيّة، وليس بصدد محاكمة- بما بوحي به لفظ (المحاكمة) من معان قاتمة. يقول الإبراهيمي في جملة تفيض تعاطفا وتسامحا مع الأديب الثّاعر ومقدّراً لما تجيش به روحه من عاطفة ويجود به لسانه من بيان: "ونفس شوقي ينبوع متدفّق بالرّحمة والحنان قبل أن تكون ينبوعاً متدفّاً بهذه الرّوائع من الحكمة والبيان. (13) إنّ (التّعاطف) معيار من الأهميّة بمكان، يوطدّ العلاقة بين القارئ والمقروء لله، وبسمح برؤية النّص أو العمل بكلّ وضوح وبلا حجاب أيّا كان. مِعْيَارُ الثَّقافة (تُقافة النّاقد والأديب)

2.1.3

يذهل الإبراهيميّ متلقيه بسعة مقروئه الأدبيّ الثّعريّ العربيّ القديم، وهو بذلك نموذجٌ لما يحسن أن يتّصف به النّاقد والأديب من تخصصّ نوعيّ وتبحّر عميق، ذاك في علمه وهذا في فنّه. وذلك ما مكّن الإبراهيمي من معرفة مصادر شوقي ومراجعه الثّّريّة، فيضع يده على ما في شعر شوقي من تجليات للثّعر القديم ومن مظاهره، بشكل أو بآخر. فهو يدرك هذه الظاهرة الأدبيّة التي عرفها النّة المعاصر بـ (التّاص)، وعرفها النّق القديم بأسماء أخر، بعيداً عن اصطلاح (السّرقة الأدبيّة). فيقول الإبراهيميّ واصفا الظّاهرة الملحوظة بعبارة منأدبة: "وشوقي يلمس في مناحيه الفكرية آراءً ومنازع صوفية للقدماء ويكسوها حلا شعرية تذهل بروعتها عن تعرف حقيقة رأيه ويغطي الافتتان بالصور الشعرية على التفكير في أصل الرأيين فضلا عن الفروق والجوامع بينهما، ولشعر شوقي في بعض المواقف إثراق كإشراق البرق، يبهر فيخفى فيه ما يكاد يظهر ."(14)

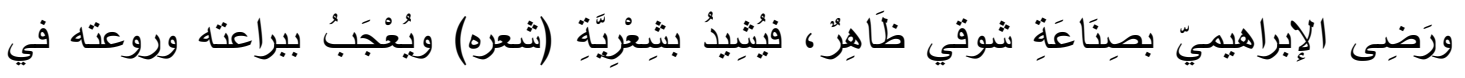
استدعاء النّصوص الغائبة والوامضة وحُسنِْ نوظيفها، حيثُ لا ينتبه إلى أصولها ولا يعرف مصادرها إلا لإِيَ 


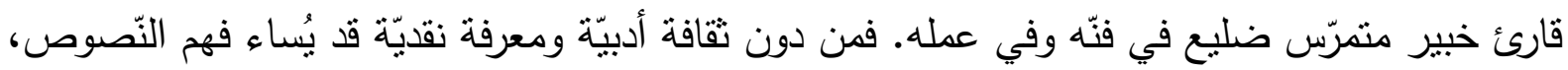
بل قد تؤوّل على غير دلالاتها، وعلى غير توجيهات سياقاتها. ولا يتيسّر تقويمها بما نستحقه من تقويم.

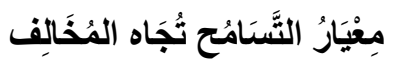

يستبين هذا المعيار من خلال موافقة الإبراهيميّ للثّاعر شوقي في دعوته أهل الأديان إلى ملى

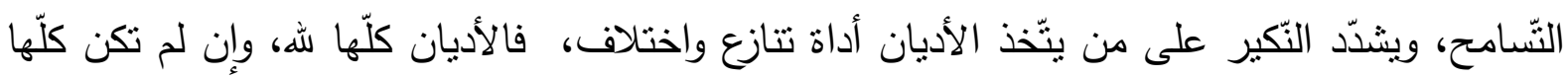

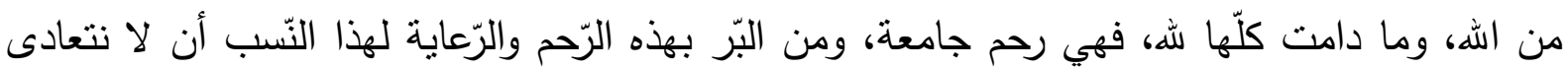

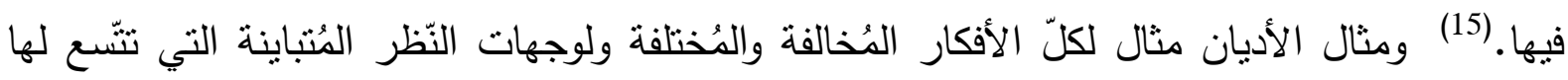

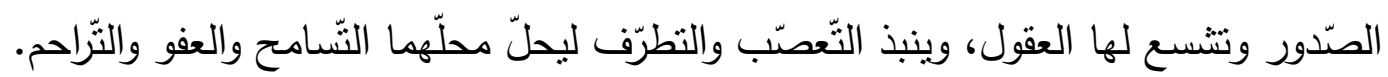

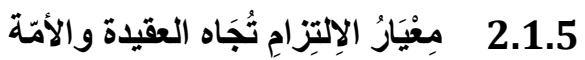

أرجع الإبراهيميّ دعوة التّّامح عند شوقي إلى ولائه للآدّوة العثمانيّة، والتزامه بها، وهو مظهر

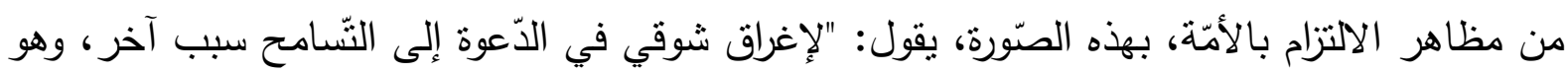
أن الذّعوة العثمانيّة الني هي ليلاه ومناط هواه، ومعقد رجائه في إعزاز الإسلام كانت راعية للأدئ لأديان

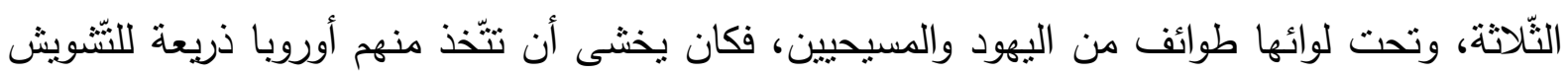

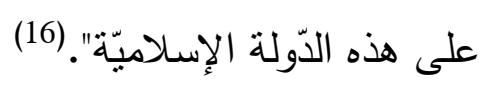

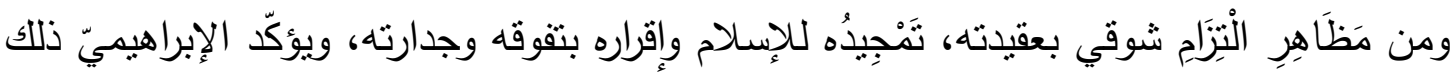

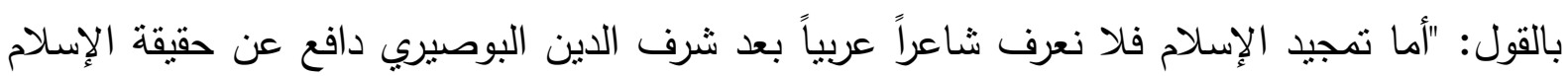

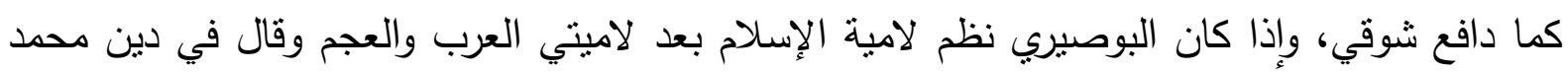
وكتابه:

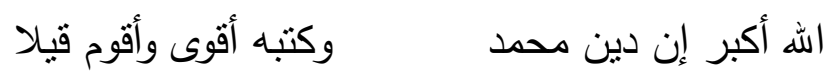
ثم ضرب له ذلك المنال الثرود في قوله: - م لا تذكر الكتب السوالف عنده لع الصباح فأطفئ القنديلا

ضرب شوقي في مدائحه وسائر شعره بالأعاجيب وأورد العشرات من الأمثال الثوارد، وأعانه

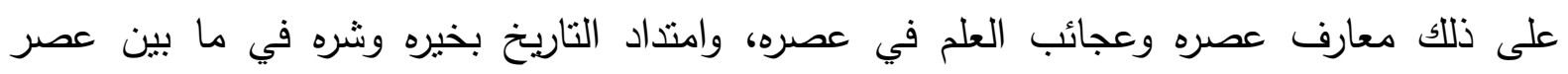

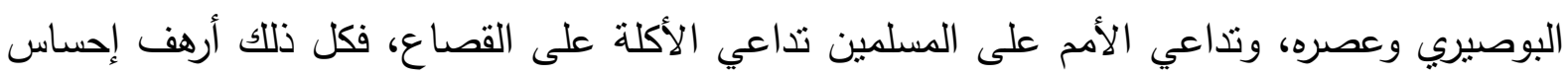
شوفي وهاج شاعريته وأثنار أثجانه، فهب الأدافع عن الإسلام ويجهز من شعره الكتائب لا الكتب".(17)

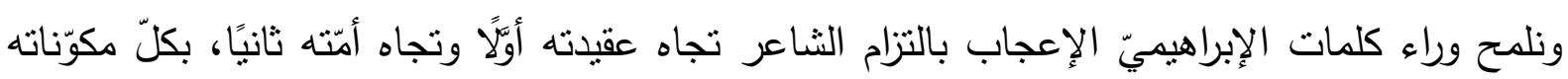

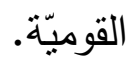


وهكذا، يَجْمَعُ الإبراهيميُّ في تقدير شوقي وشعره بين الفنّ والفكر ، بين الثّّكل والمحتوى، ويؤكّد

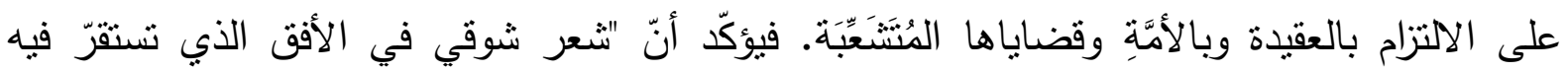

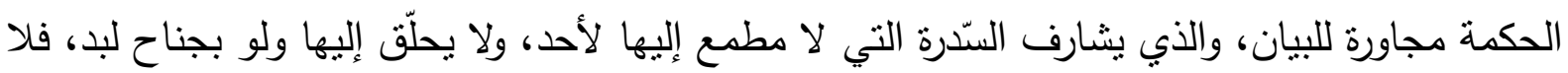

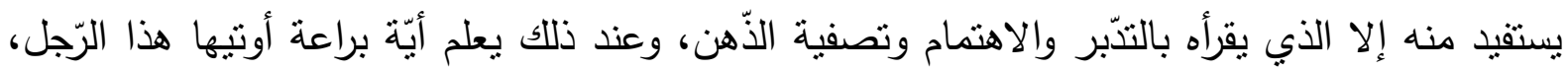

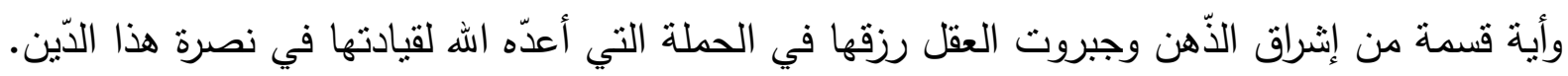
وفي أثناء ذلك تجد الغرائب من عرض سماحة الإسلام وخصائصده، وجمعاه بين القوّة والرحمة، وبنائه على العدل والإحسان وتجاربه الناجحة في هداية البشر وفي بناء الحضارة وفي إمامة العلم، وفي قيادة

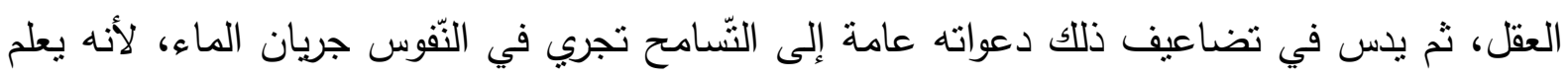

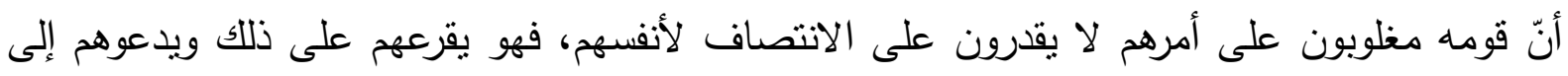

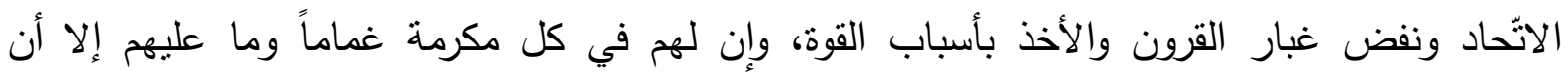

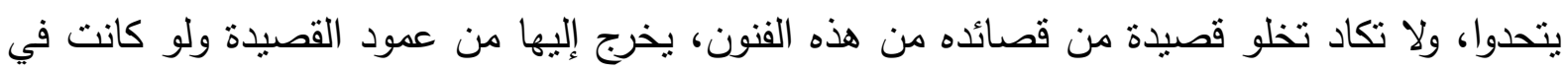

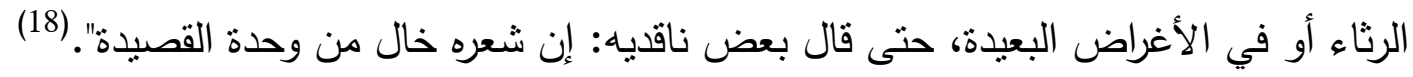

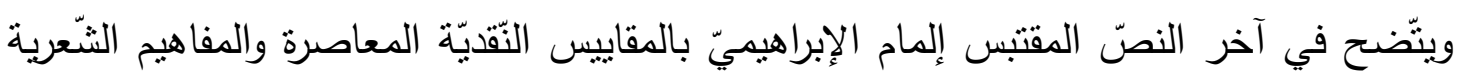

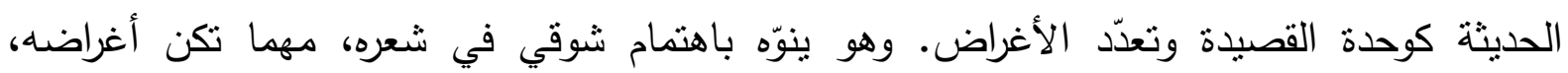

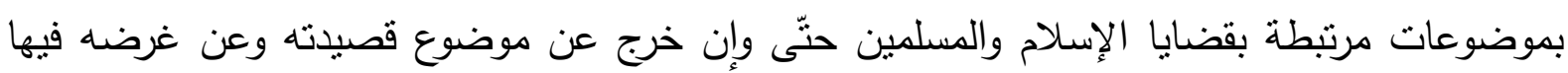

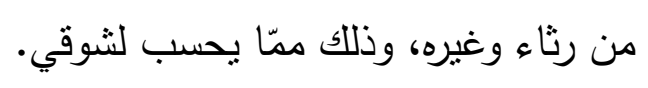

2.1.6 مِعْيَارُ النَّصَّ/الأدب بدلَا عن النّاص (الأديب)

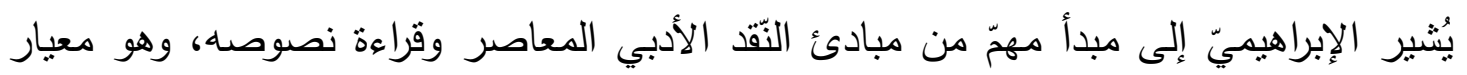

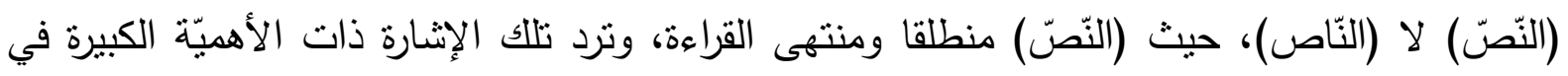

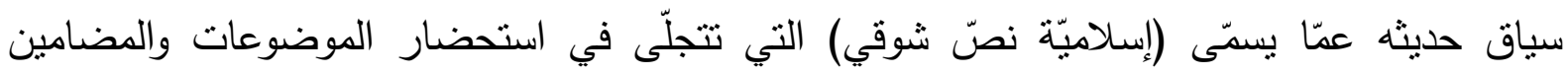

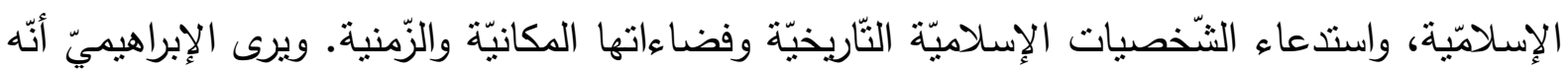
ليس من واجب النّاقد النّظر في شخص الأديب (النّاص) لتقييم نصه أو تقويمه، كما يبدو في دراسته الإنها

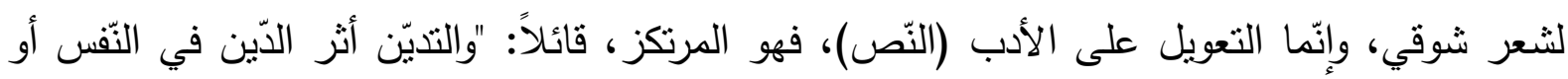

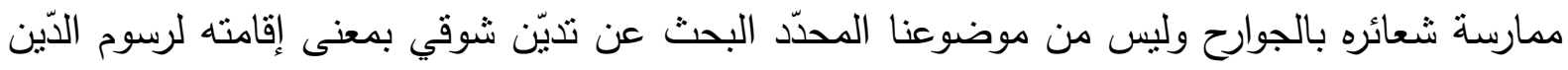

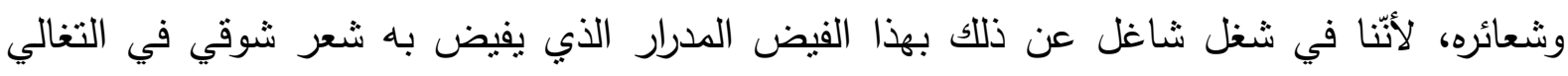

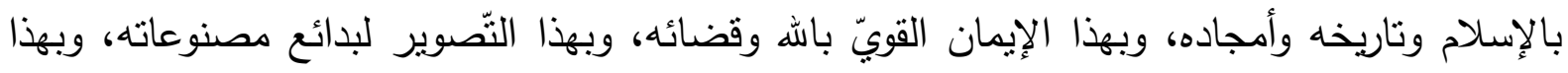

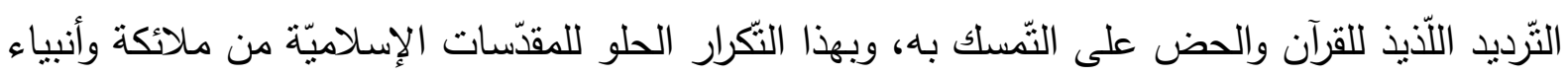
وصحابة وأماكن وأيام، فيغشى في شعره ذكر الله وجبريل ومحمد وإبراهيم وموسى وعيسى وعمر وخالد

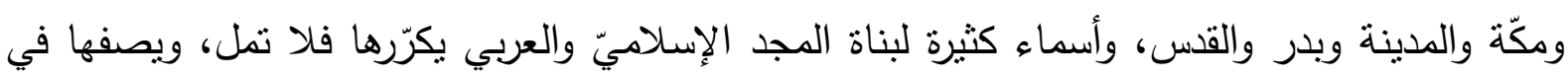




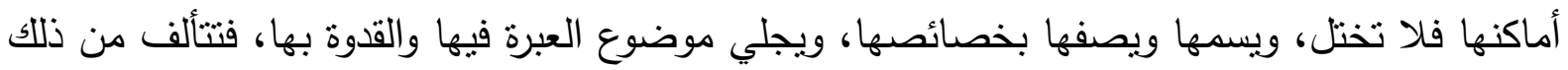

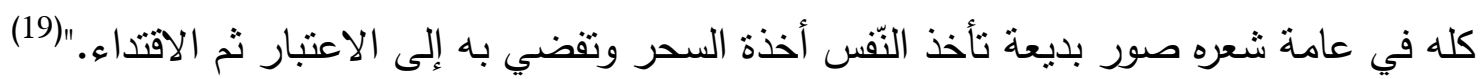

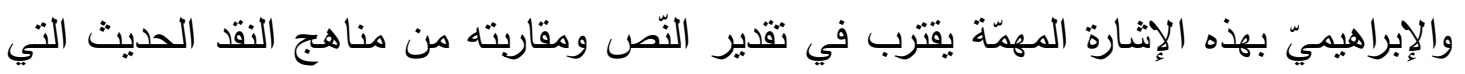

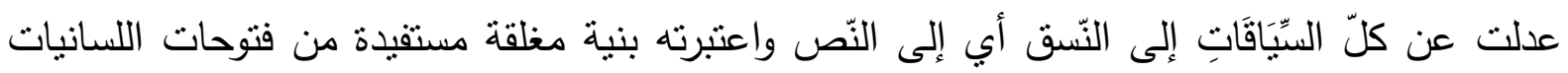

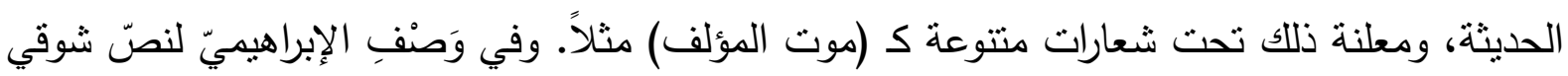

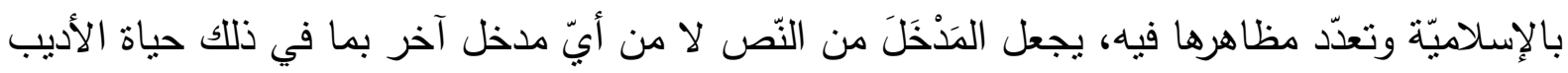
(الثّاعر) أو سيرته. ومن مظاهر إسلاميّة شوقي في شعره أنّه يحتكم إلى شمائل الإسلام وأخلاقه الإنه

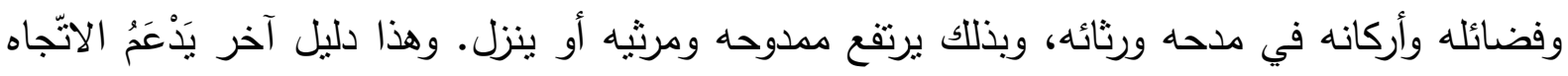

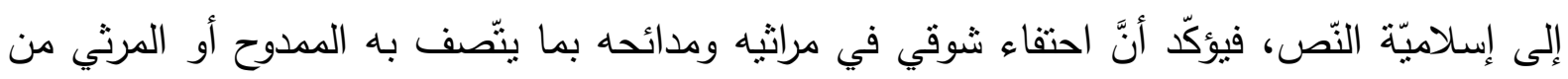

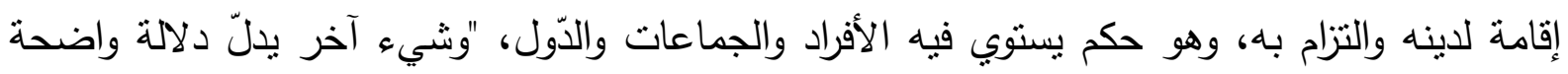

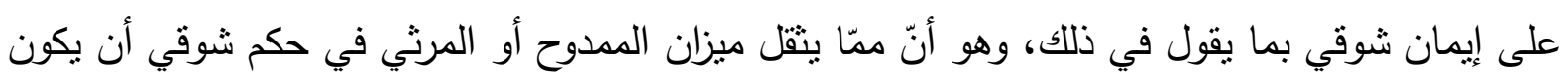

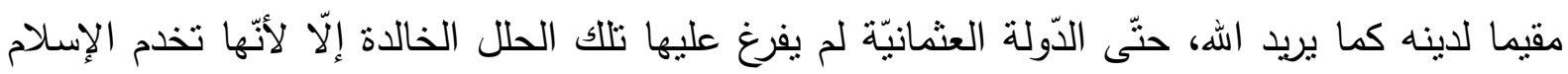
وتعمل لإعزازه." (20)

ويستحضر الإبراهيميّ الثُّواهد والأمنتة تصديقًا لرأيه، في إسلاميّة (النّاص) من النّص، منها قول

$$
\text { شوقي في رثاء حسين شيرين:" }
$$

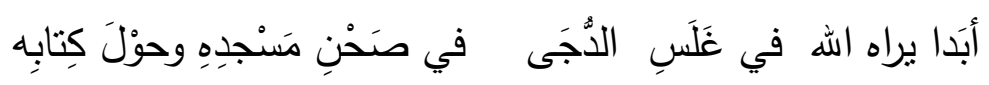

$$
\text { وقوله في تعزية أهل دمياط(21): }
$$

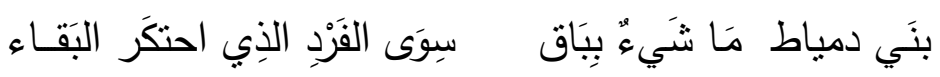

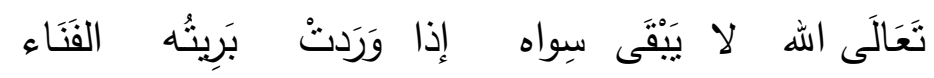

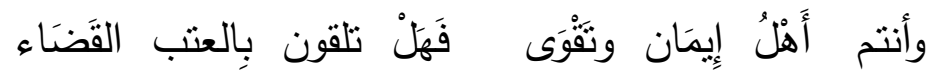

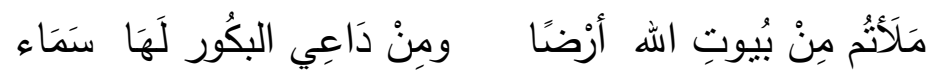

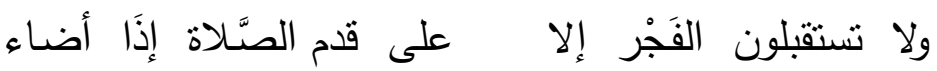

وهناك شواهد كثيرة يلجأ إليها الإبراهيمي في تعزيز رأيه، فيقول: "وفي هذه القطع منازع لطيفة في فقه

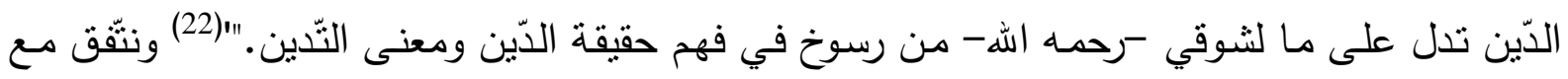

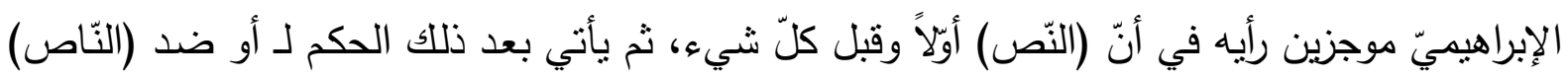

$$
\begin{aligned}
& \text { من (النّص) ذاته، وهو مبدأ مقرّر في نقد هذه الأيام. } \\
& \text { مِعْيَرُ الرَّسَالَة فِي الأََبَ (النَّص) }
\end{aligned}
$$

يدلّ معيار (الرّسالة) في الأدب، على معلى معلم من معالم الأدب الإسلاميّ، فلأديب رسالة يؤدّيها

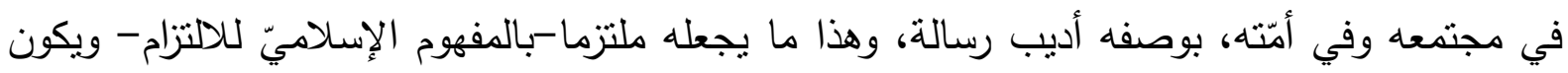


لعمله غاية تبرّر وجوده بشكل ضمنيّ أو صريح، ويخلو من العبث المطلق الّّي لا نستسيغه الفطرة ولا

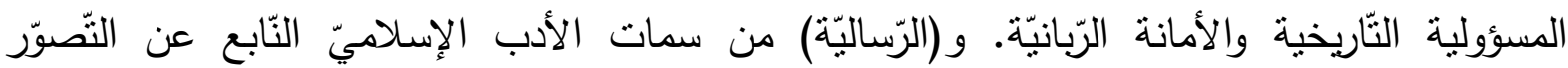

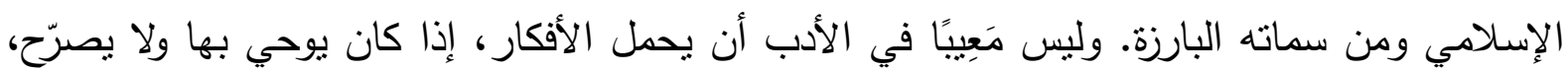

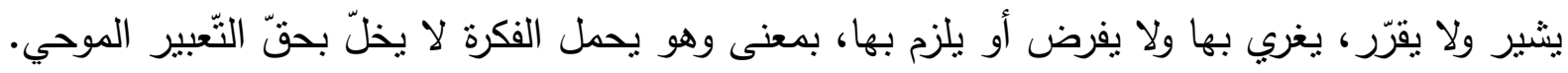

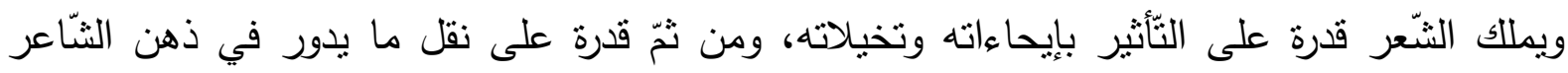

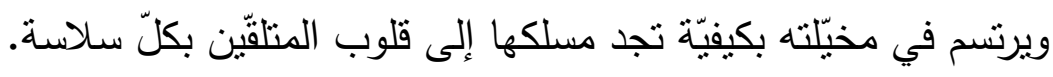

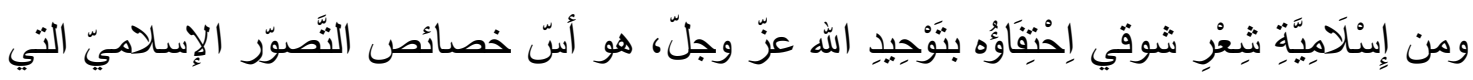

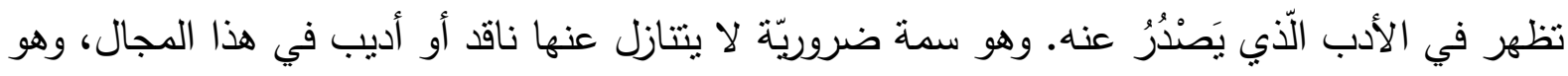

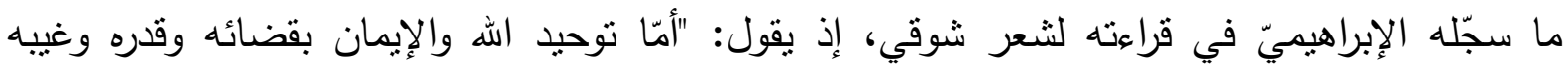

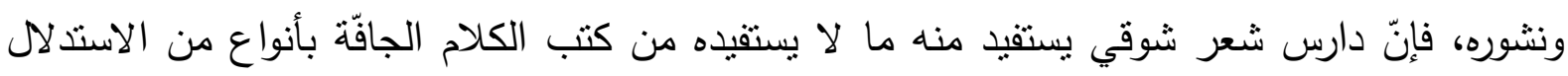

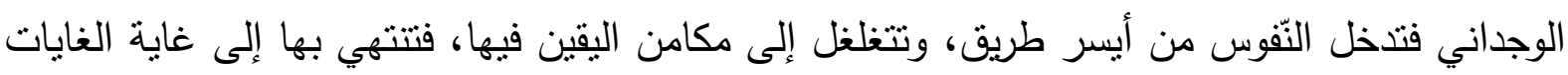

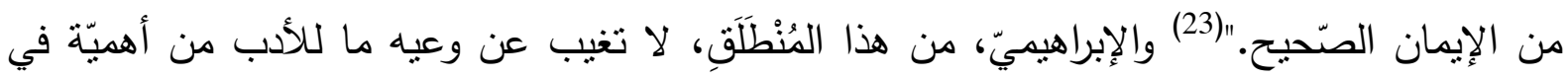

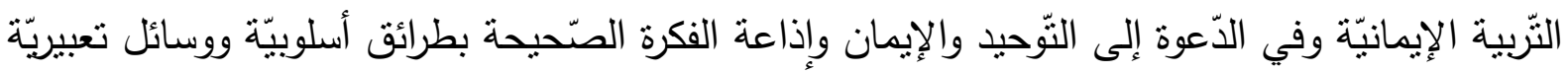

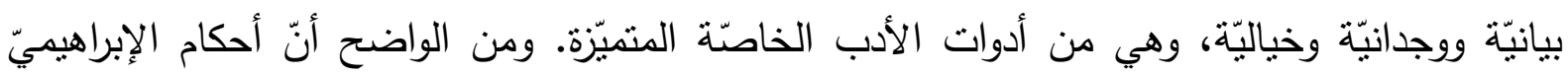

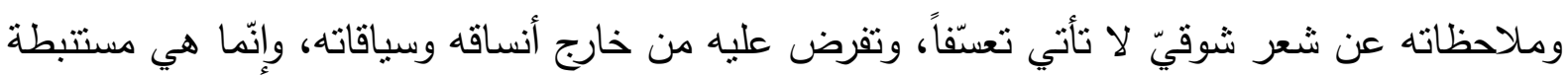

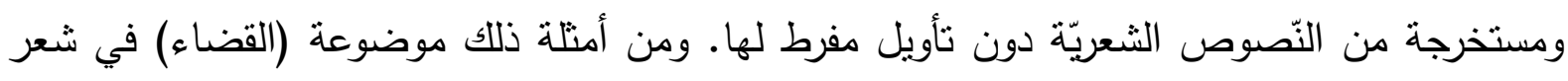

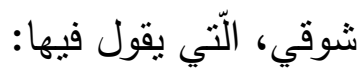

$$
\begin{aligned}
& \text { القضَّاءُ مُعْضِلَة }
\end{aligned}
$$

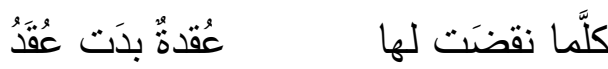

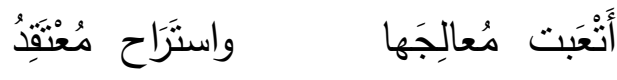

$$
\begin{aligned}
& \text { ومثال آخر ، يقول شوقي عن (البعث) و (النّشر)، في نولستوي(24): }
\end{aligned}
$$

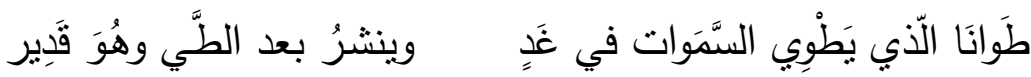

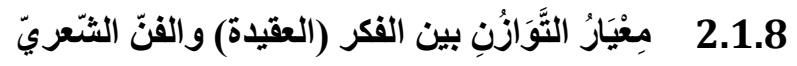

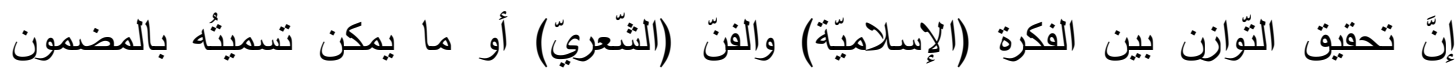

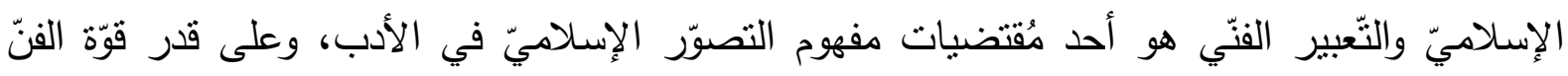

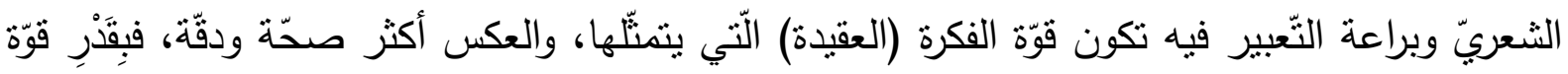

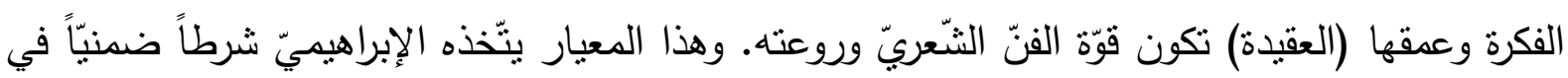


قراءته لثعر شوقي، فيرى في براعة شوقي وإتقانه لفنّ القول، لاسيما في مدائحه النّبويّة، دليلاً قويّاً على

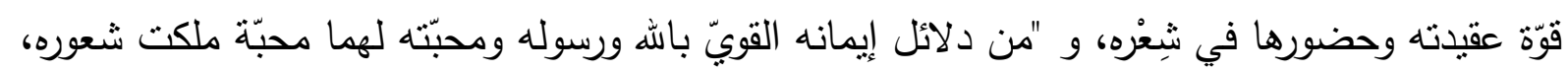

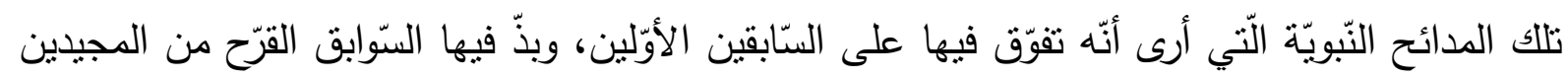

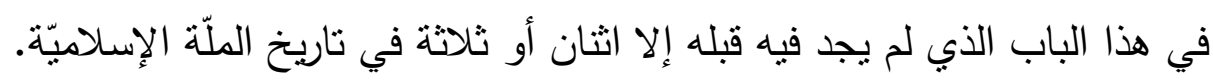

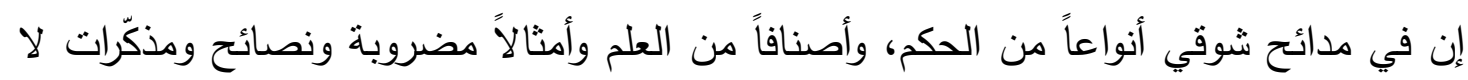

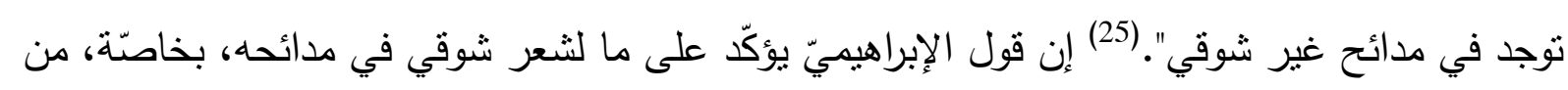

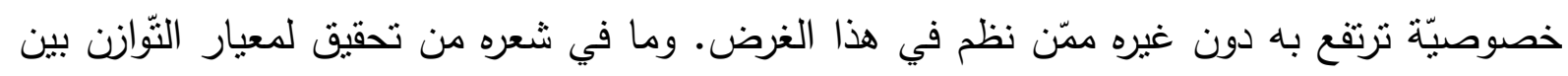

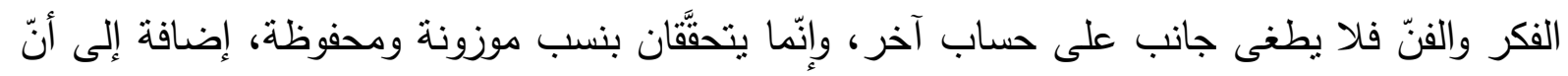

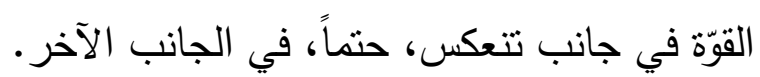

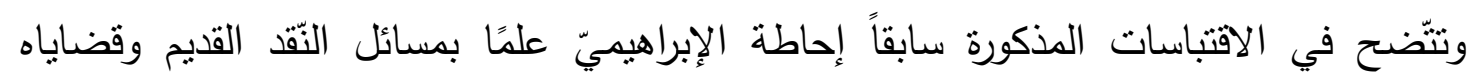

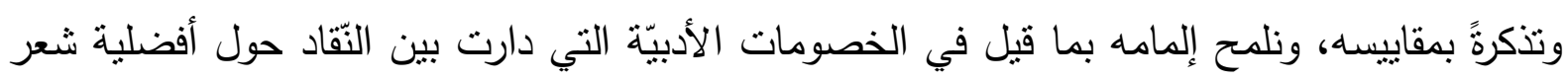
على شعر ، وعلاقة الدّين بالثشّر .

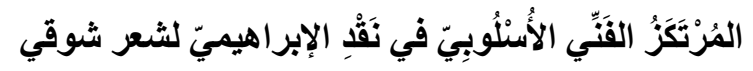

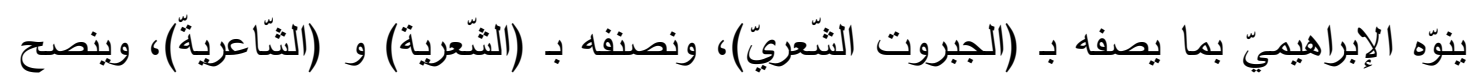

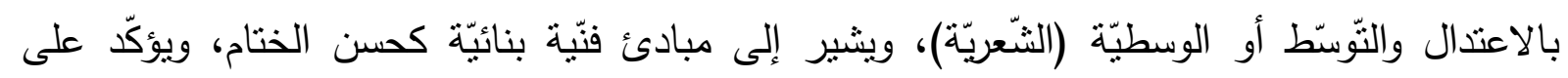

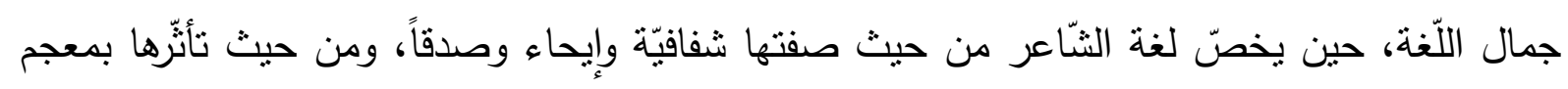

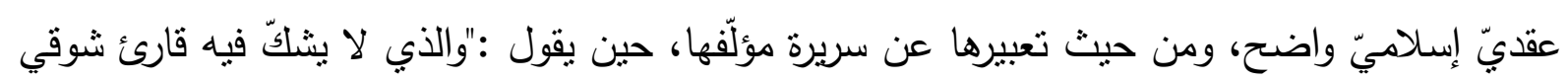

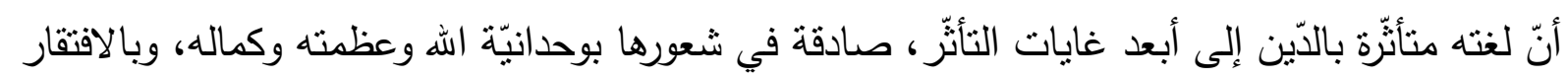
إليه والخوف منه". (26)

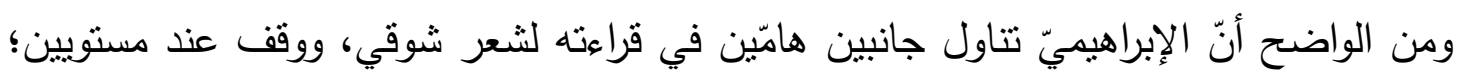

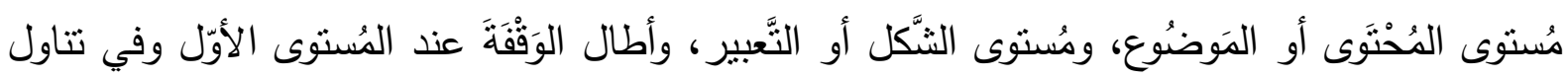

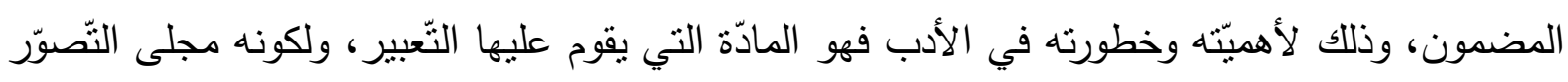

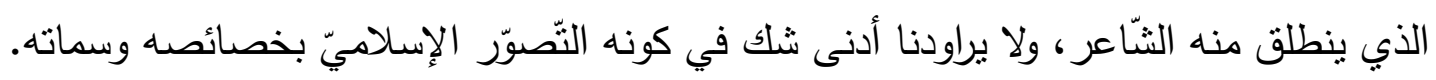

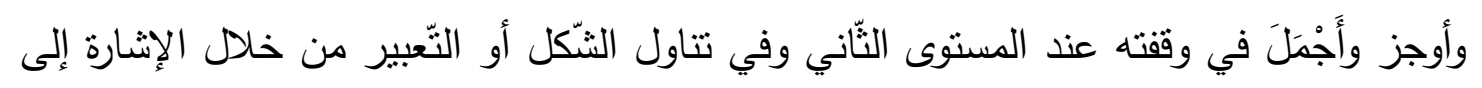
لغة الثّاعر وإلى معجمها الإسلاميّ وقدرتها على الإيحاء والدّلالة على انفعال الثّاعر وامتلائه بإيمانه.

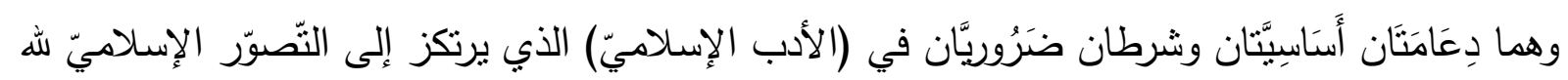

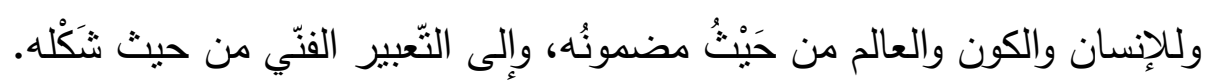

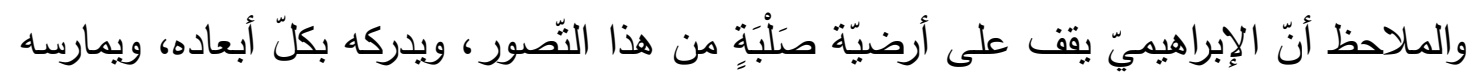

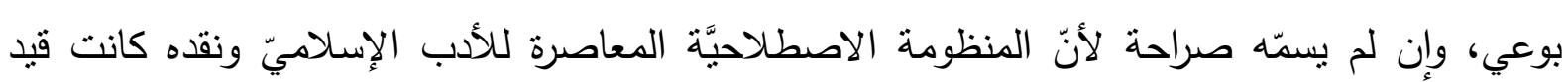


التَّأْبِيس في تلكِ الفترة، ولم تتبلور بالثنّكل الكافي وإن كانت تُمَارَسُ بطريقة أو بأخرى، كما يبدو في

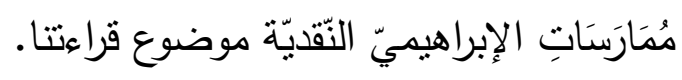

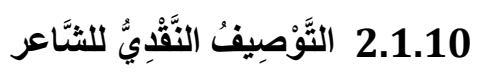

بناءً على تقدير الإبراهيميّ لشعر شوقي، فقد خصنّ الثَّاعر بعناية لافتنة للانتباه، وأنزله مَنْلَكَة

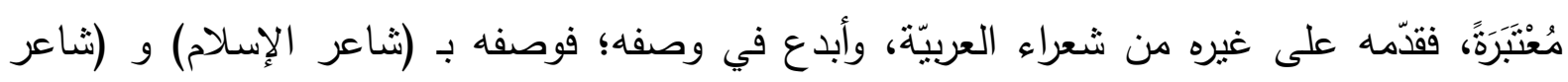
العربيّة) و (ثناعر الثّرق)، وفي سياق واحد نعته بالنّعوت الثناثة وبكلمة واحدة (ثناعر الإسلام والعربيّة

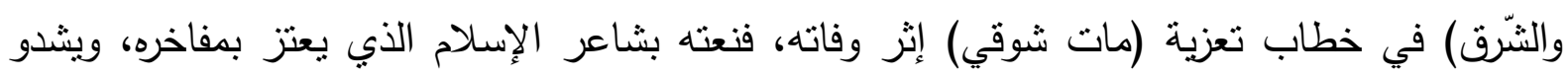

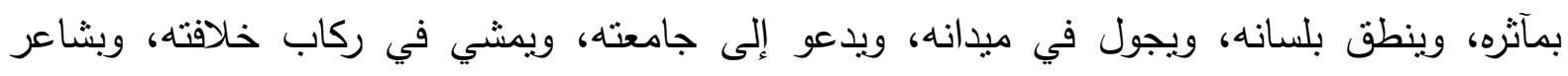

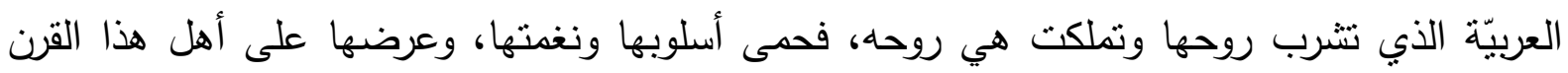

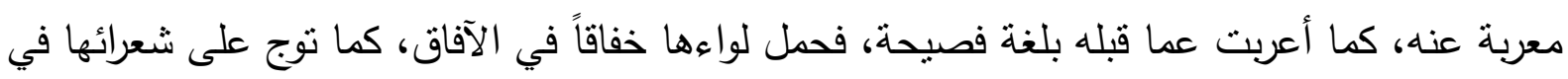

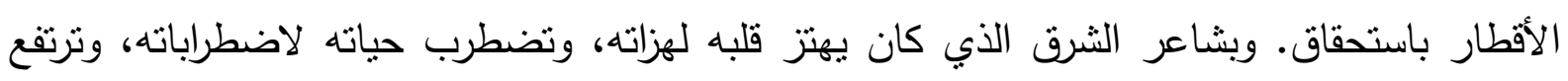

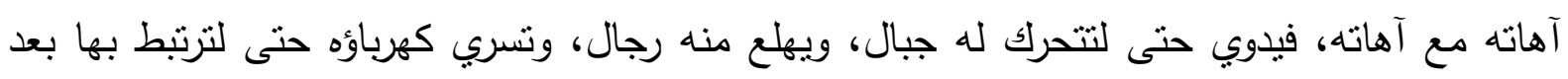

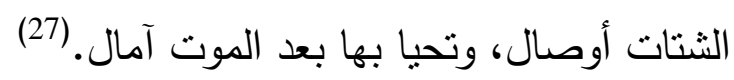

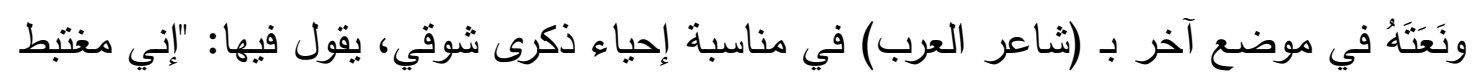

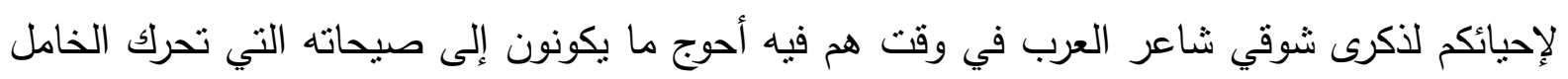

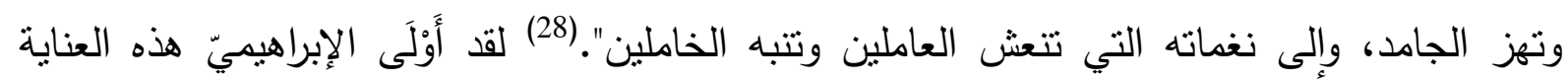

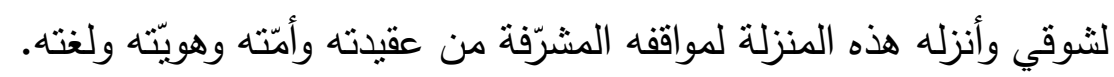

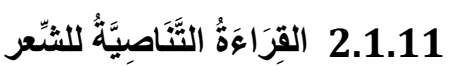

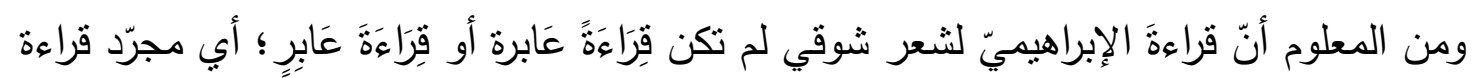

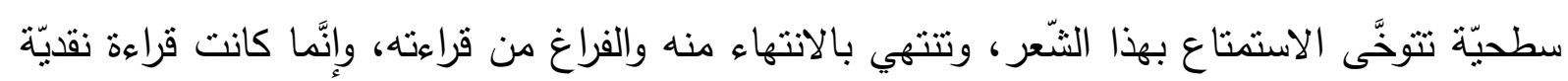

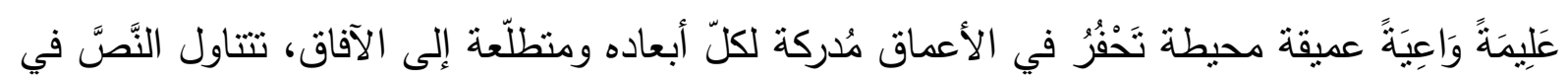

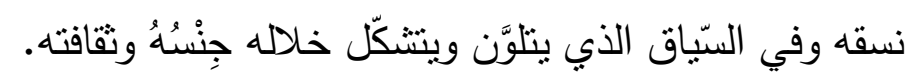

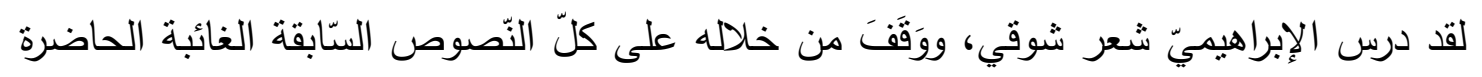

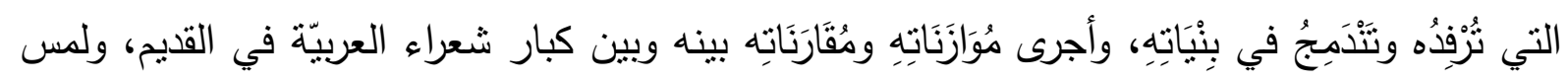

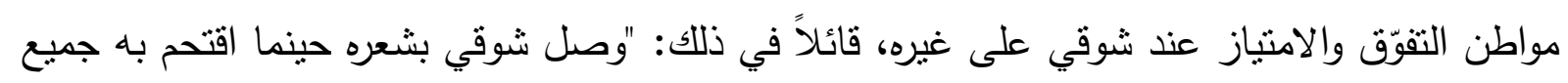

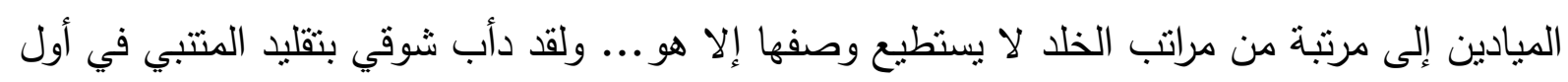

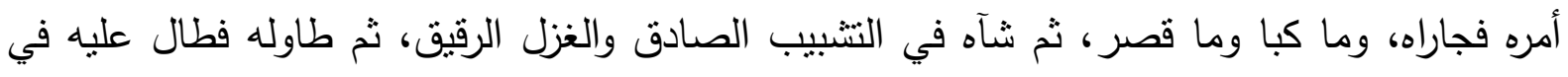

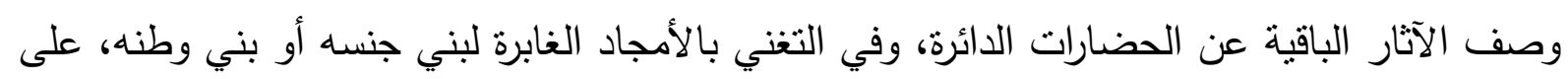

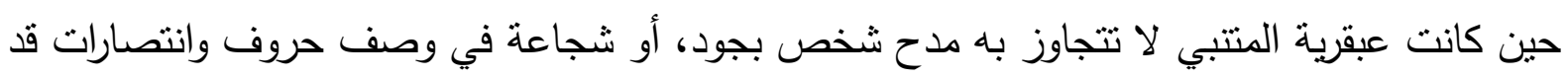


يكون الغناء فيها لغير المدوح، ولا تبرز العبقرية إلا في الحكم التي سجلها والأمثال التي سيرها، أما

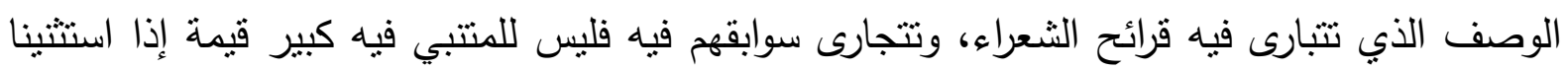

قصيدته في شعب بوان وقصيدتيه في وصف الحمى وفي وصف الأسد وفي قطع قليلة من شعره". (29)

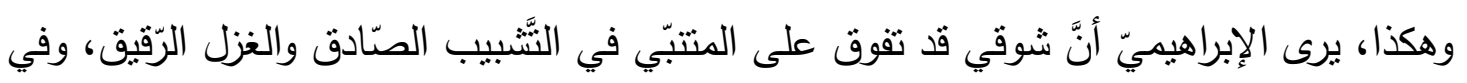

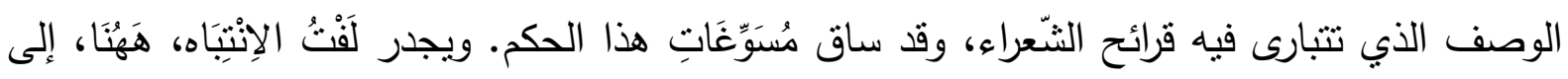

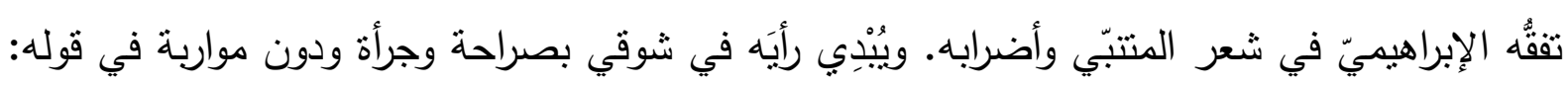

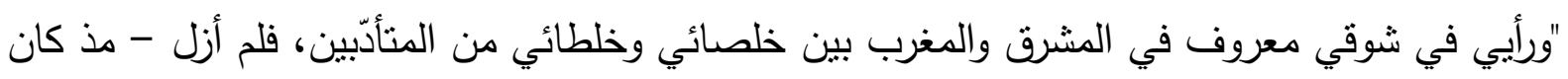

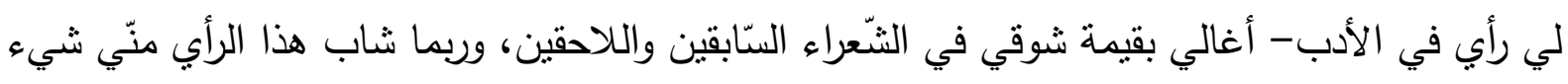

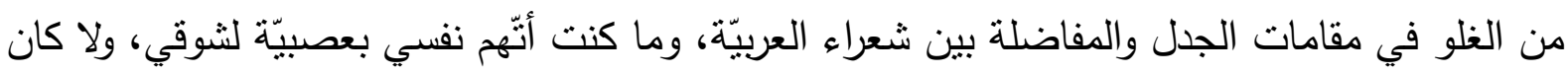

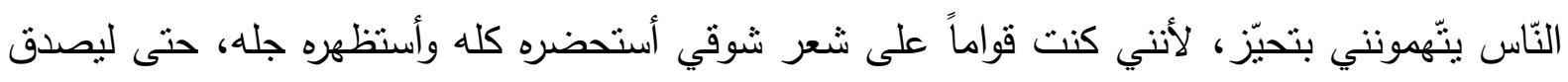

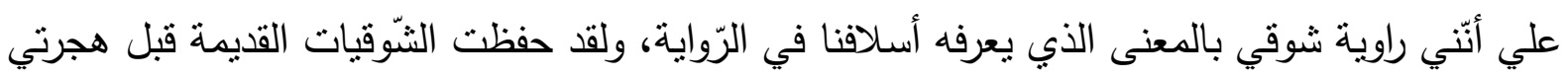

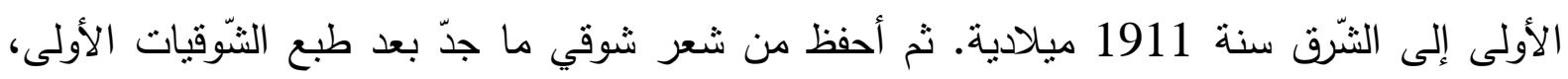

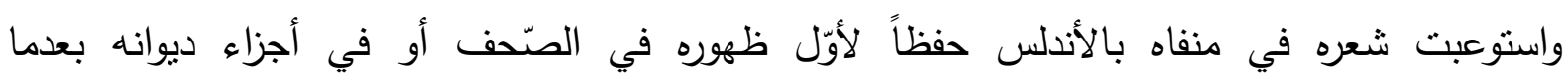

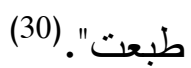

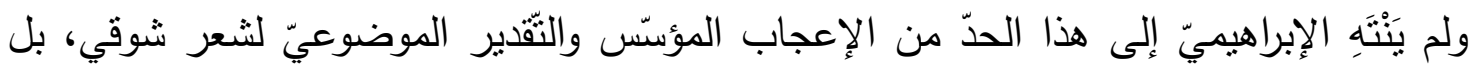

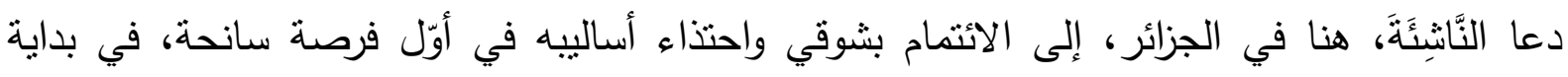

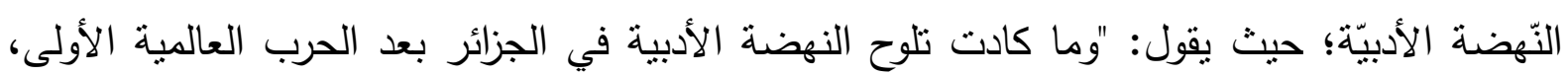

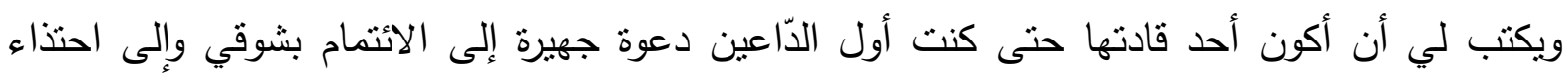

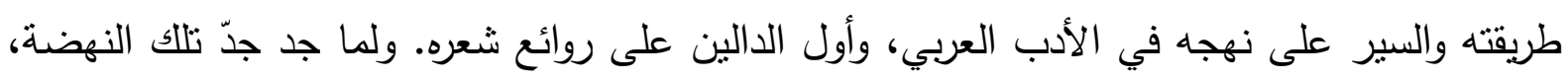

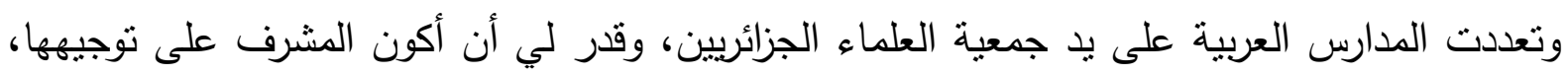

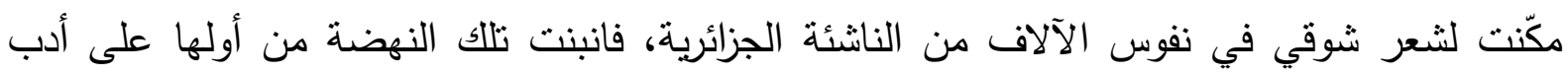

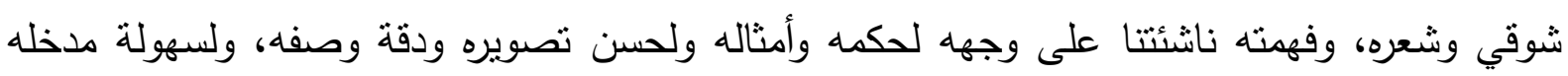

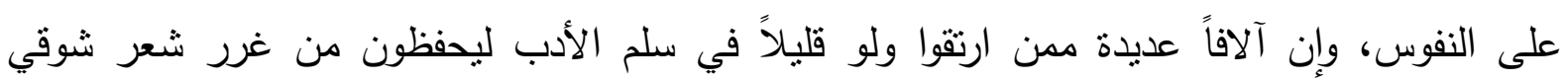

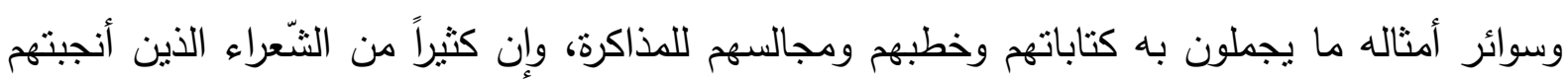

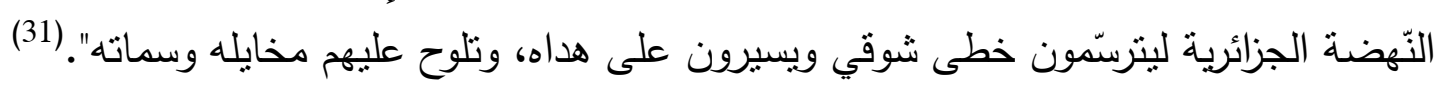

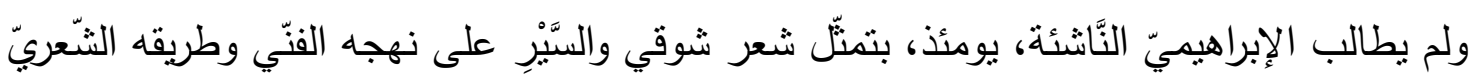

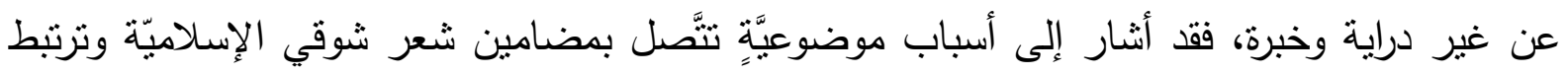

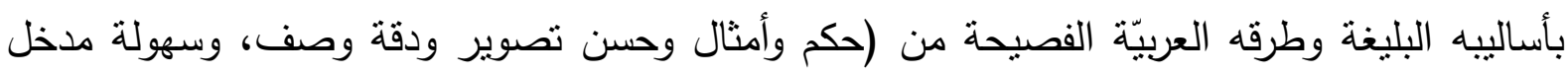

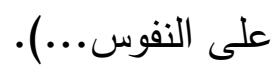


ومن عوامل تَمَكِينِ شعر شوقي وأدبه في مقرّرات وبرامج المدارس ونفوس النّانشئة شدّة ارتباط

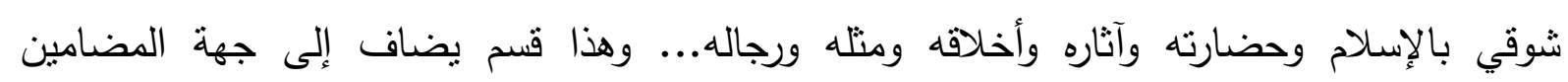

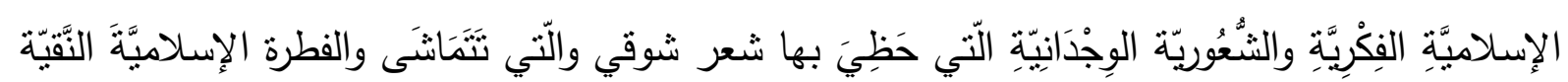

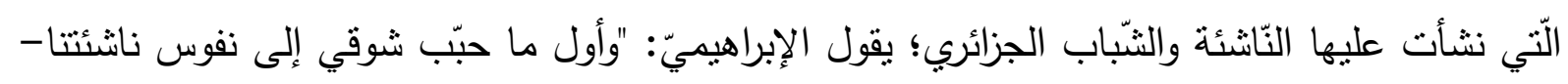

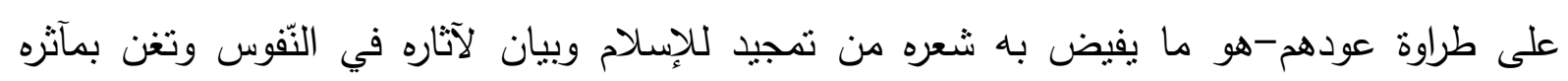

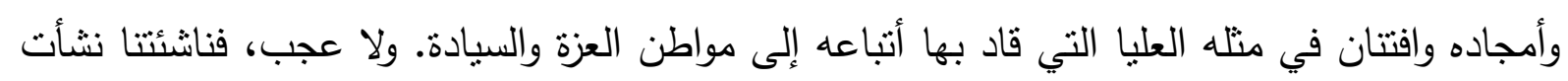

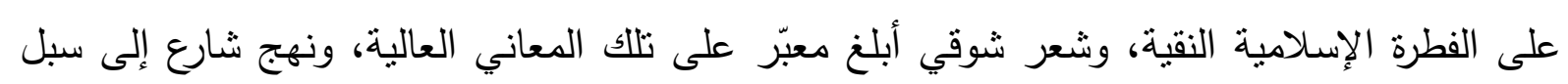

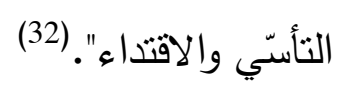

ولهذا كلّه، كان موت شوقي بالنّبة للإبراهيميّ ولأندية الأدبيّة الناشئة بالجزائر خسارة فادحة

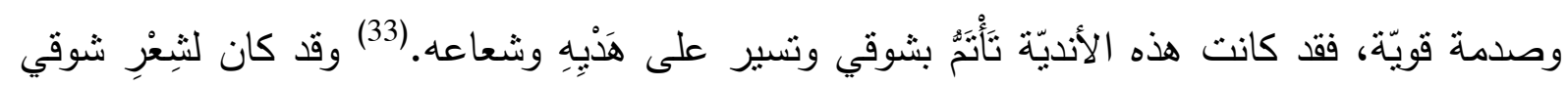

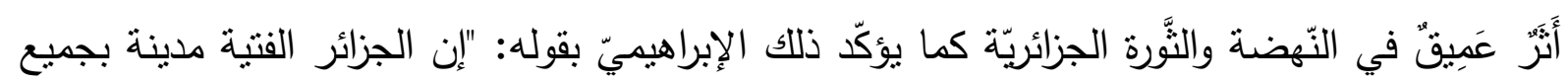

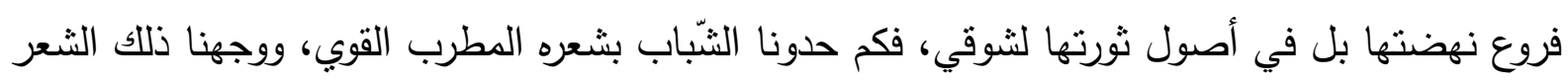

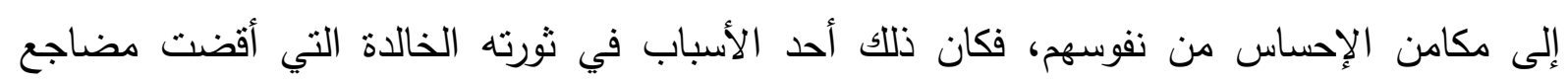

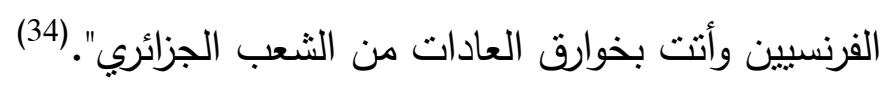

$$
\text { وفي ختام عرضنا لقراءة الإبراهيمي لثوقي لا بد من التأكيد على ما يلي: }
$$

- إنَّ قراءة الإبراهيميّ لشعر شوقي هي قراءة تلمّ بعناصر شتّى بدءاً من الأديب (المرسل) إلى أدبه

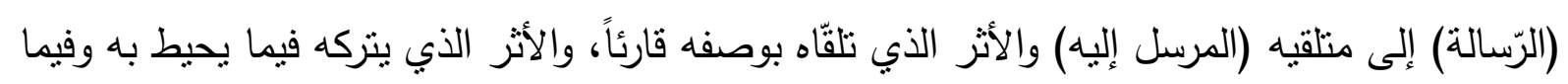
يأني ويحتمل أن ينتج من نصوص.

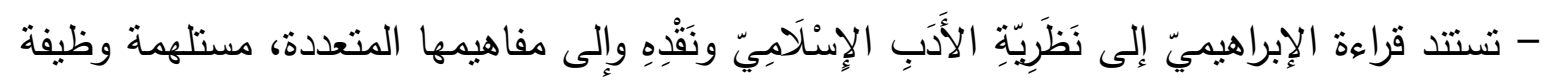

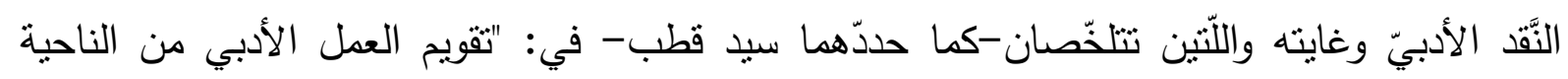

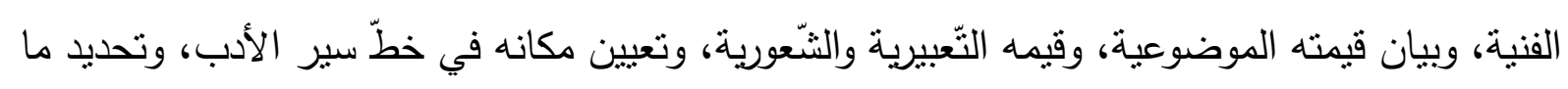

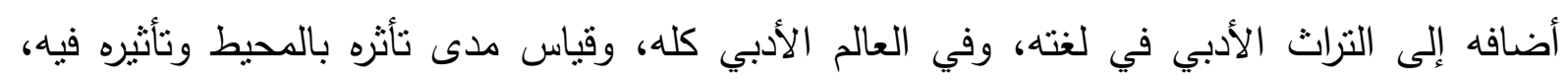

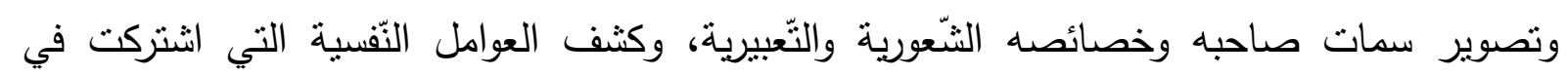

تكوينه والعوامل الخارجيّة كذللك."(35) وخئ

- ثُشْهُج قراءة الإبراهيميّ في تعزيز الرّصيد النَّظريّ للأدب والنّقد الإسلاميين، وتُعين في استتباط

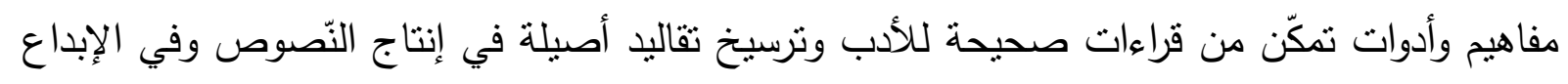
بصفة عامّة. 


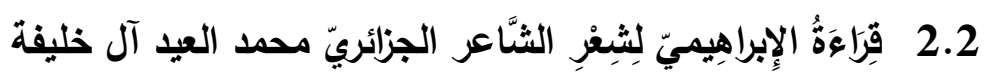

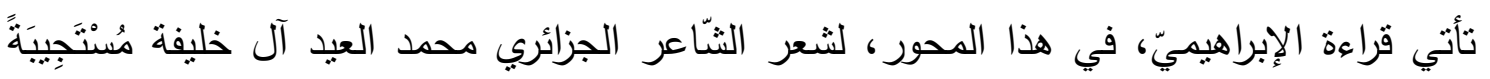

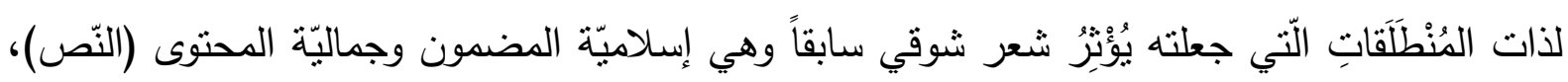
وسنتتاول هذه القراءة مستتبطين سمات الأدب الإسلاميّ ومعايير نقده.

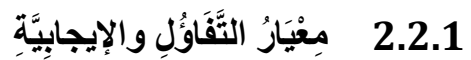

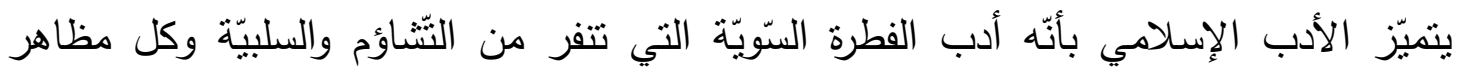

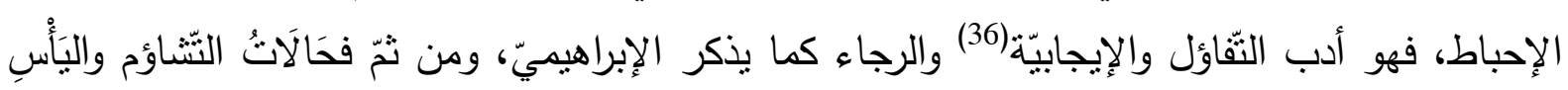

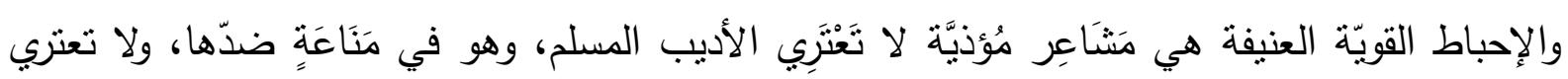

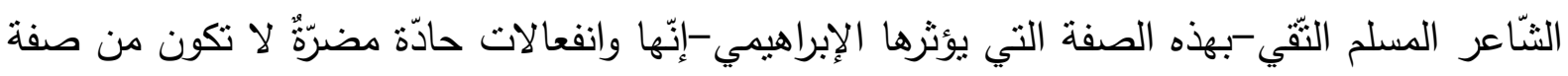
المسلم، ولا تتخلل سلوكه ولا تتمظهر في قوله.

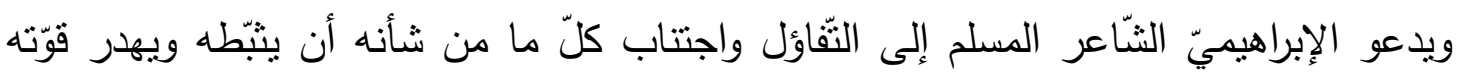

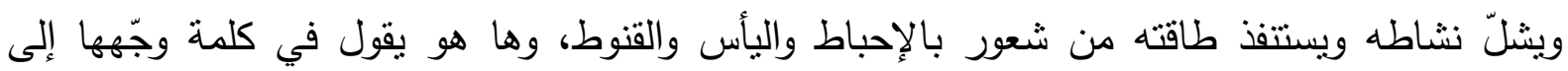

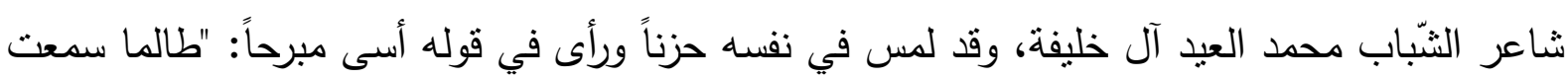

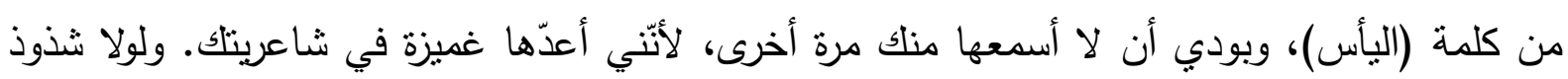

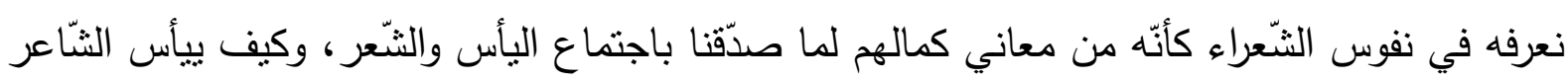

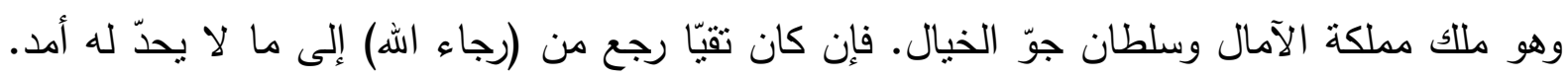
فكيف تبأس نفس الثّاعر لولا ذلك الثنذوذ؟ لقد قال أوّلكم:

\section{حرّك مناك إذا اتمـ مت فإنّهن مراوح}

وما قالها لغيره إلا بعد أن جرّبها في نفسه... فلا تيأس يا بني ولا تكذب إمامك الذي يقول: خلق الثّاعر

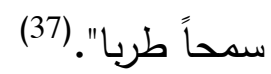

وشَيْيُ آخَرُ جدير بالتّويه وهو العلاقة الحميمة الأبويّة الإنسانيّة العارمة التي تجمع النّاقد

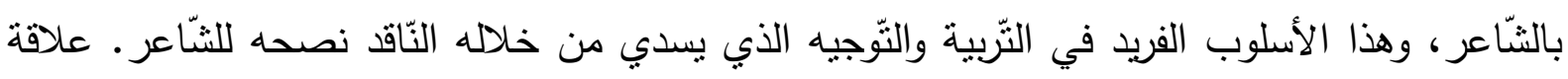

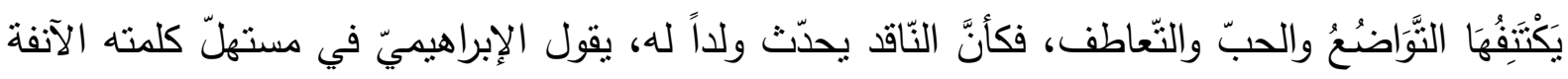

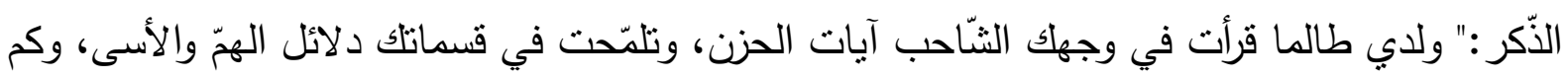

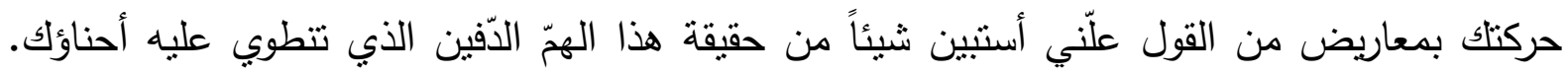

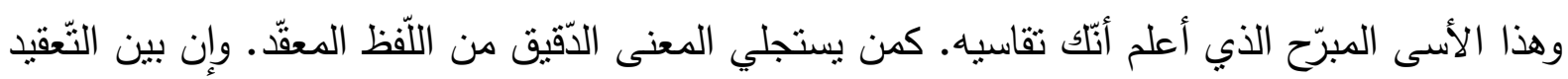

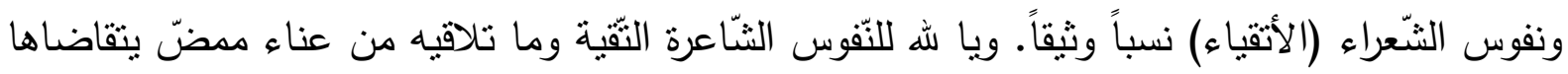

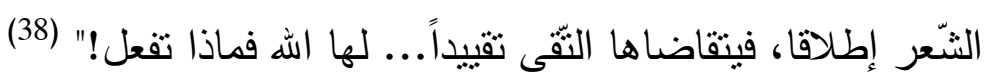


ويستمرّ الإبراهيميّ في ترسيخ سلوكه التَّربويّ الفّّ وتأسيس فنّ عال لتعامل النّاقد والثّاعر،

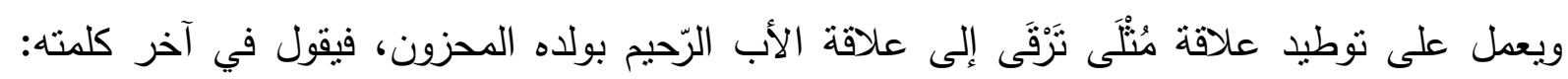

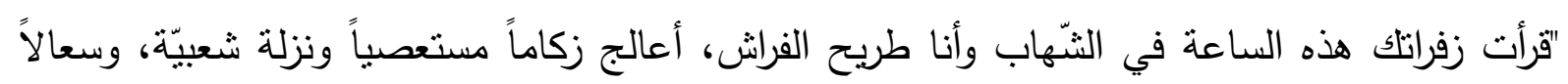

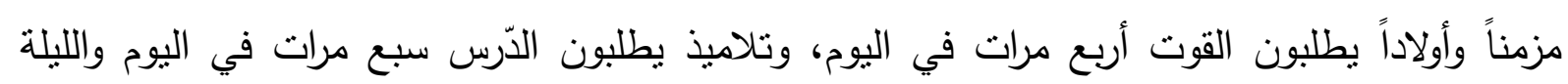

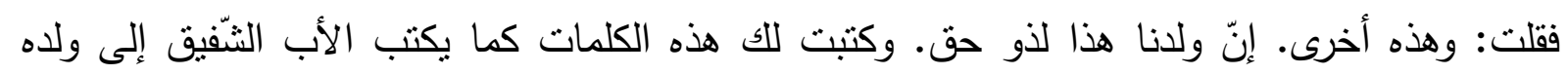

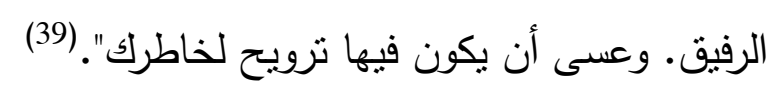

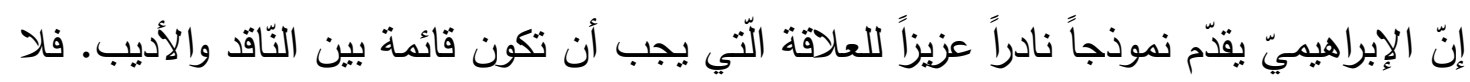

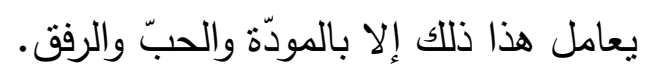

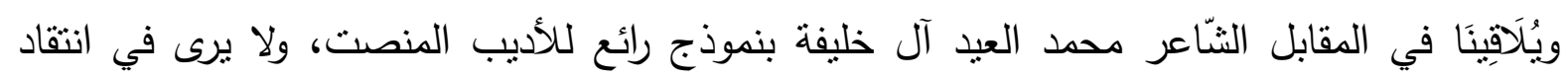

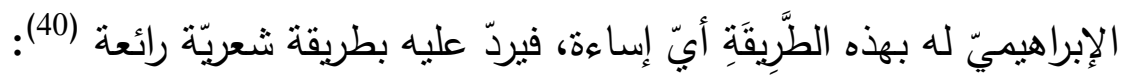

$$
\begin{aligned}
& \text { أبي (البَتير) سلام زاك وشتوق كبـير }
\end{aligned}
$$

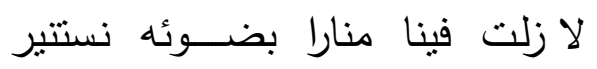

$$
\begin{aligned}
& \text { وافى كتابك يهدي إلي المنسى ويثير ليناري } \\
& \text { تذكو العبارة فيهما ليس يذكي لئو العبير }
\end{aligned}
$$

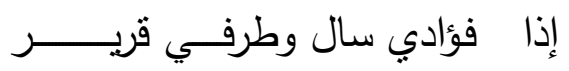

$$
\begin{aligned}
& \text { قد ارتددت بصبراً فكيف يغوى البصير؟ } \\
& \text { قميص يوسف ألقى به علي (البشير)؛ } \\
& \text { با آسي اليأس زدني كثنفا فأنت خبير }
\end{aligned}
$$

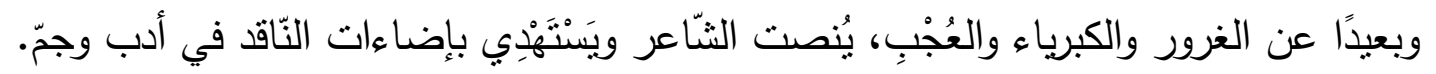

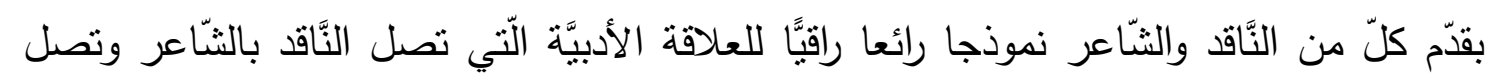
الثنّاعر بالنّاقد.

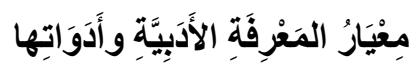

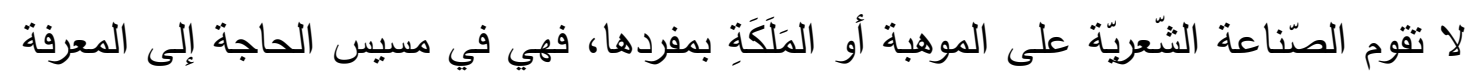

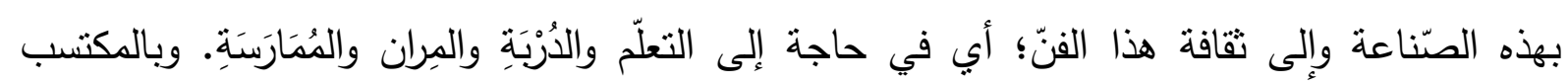

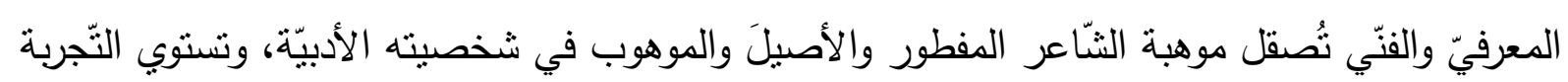
من كلّ جوانبها. وييني الثّاعر صرحه الفنّي على أسس متنينة من الموهبة والمعرفة.

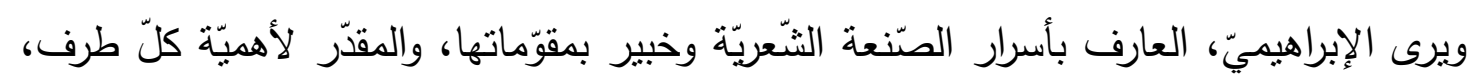

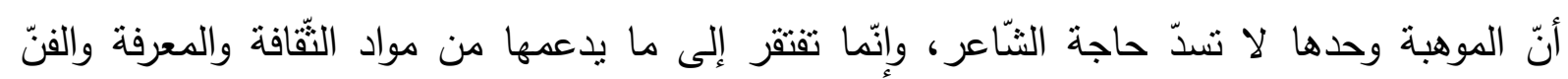

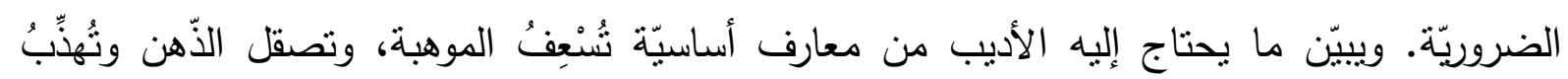




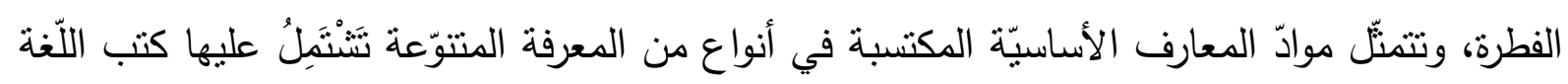

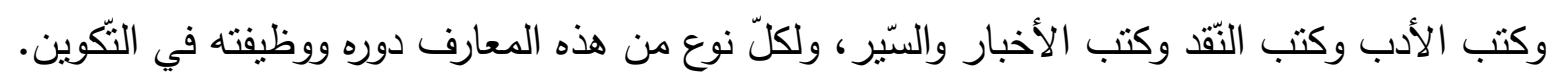

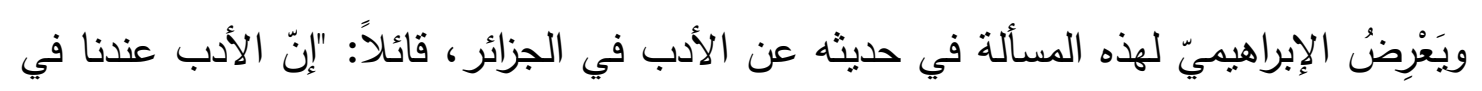

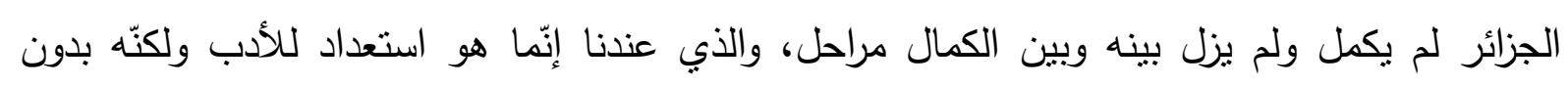

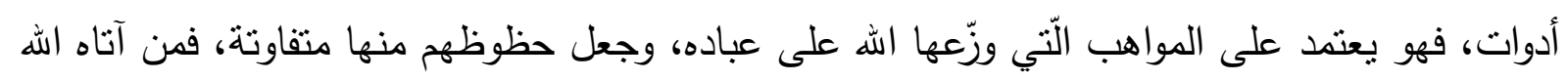

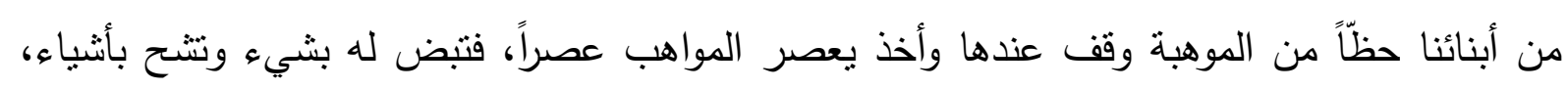

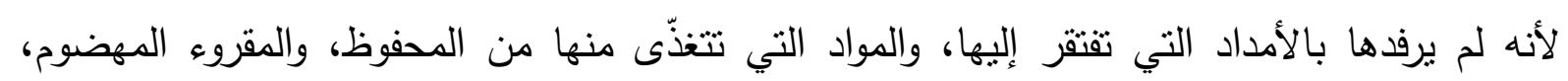

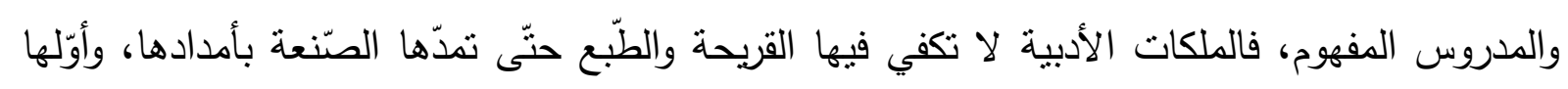

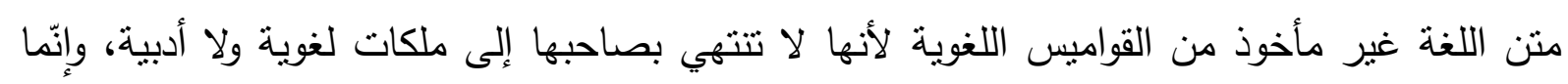

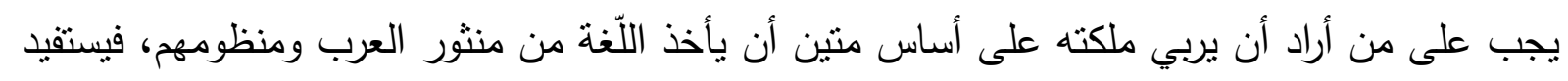

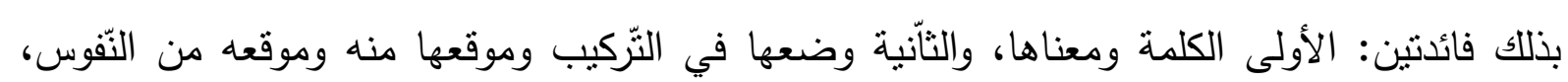

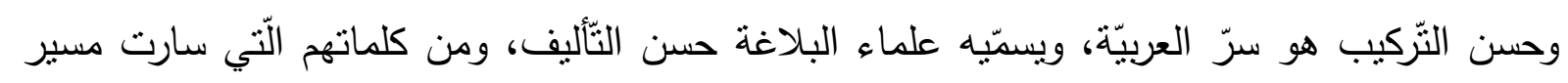

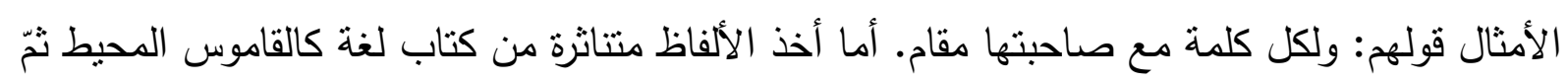

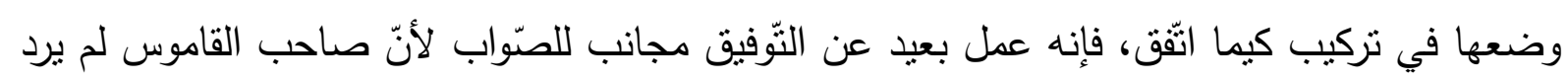

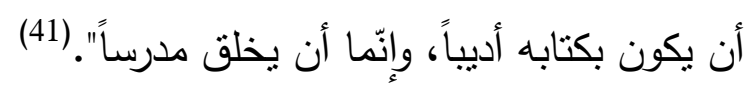

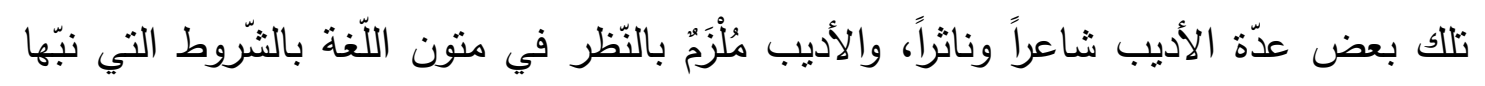

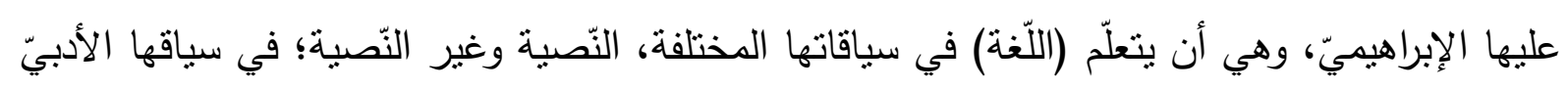

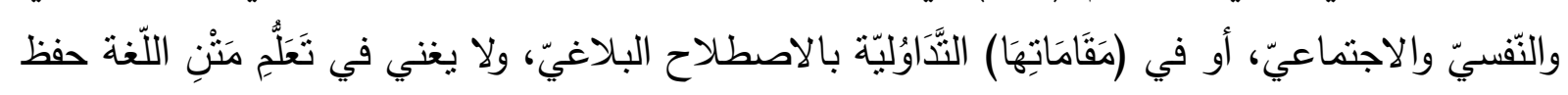

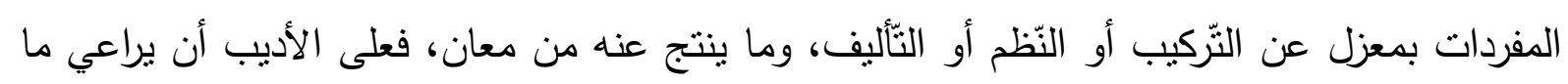

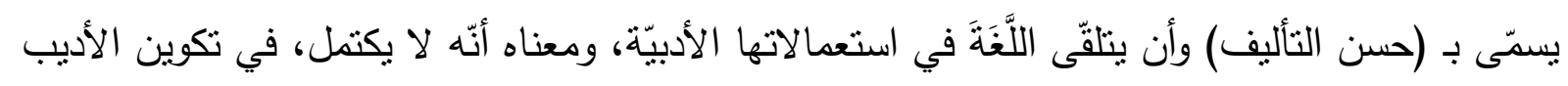

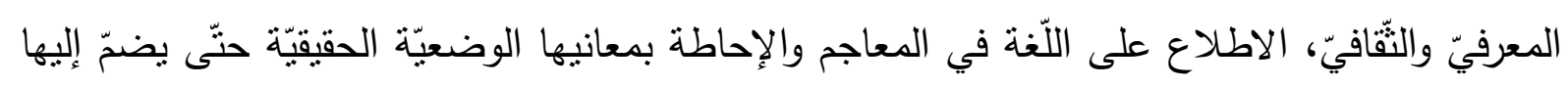
اللّغة في استعمالاتها الحيّة وبدلالاتها المجازيّة الانزياحيّة.

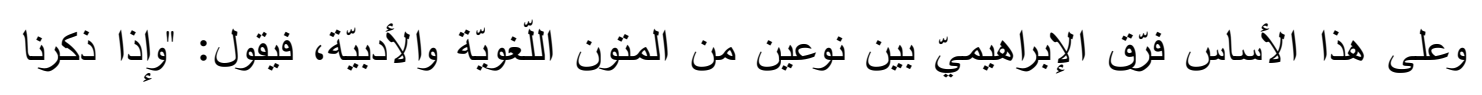

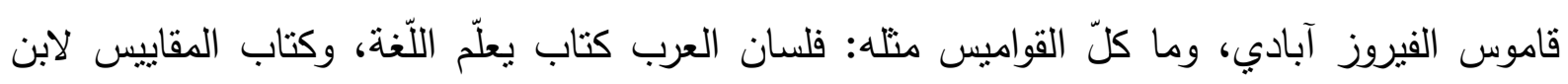

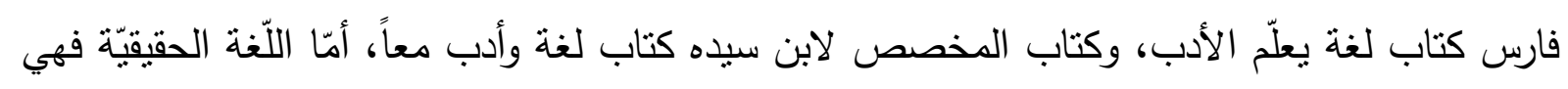

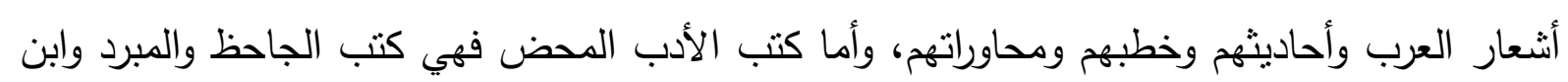

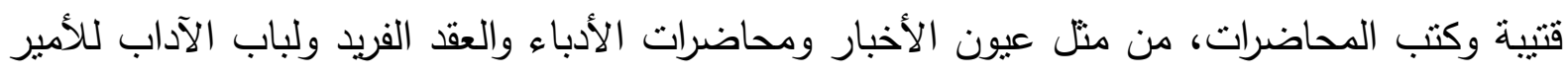

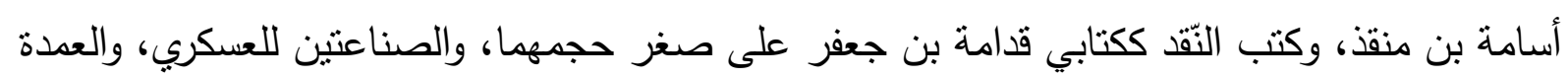

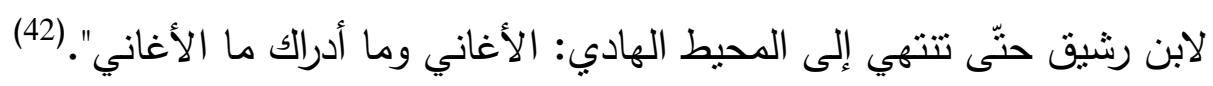


هذه، إذاً، بعض لََأَمُ الثّّافة والمعرفة الأدبيّة التي لن يكون للأديب شاعراً وناثراً غنى عنها، وبها

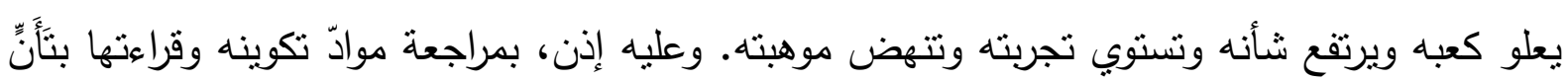

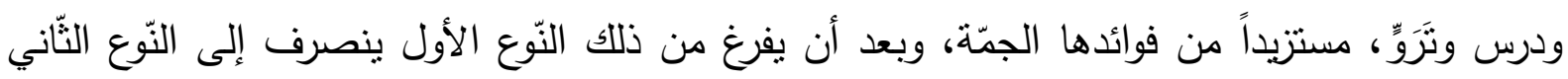

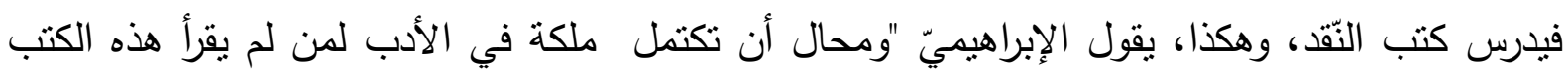
كلّها قراءة تأنّ ودرس، ويحفظ لكل شاعر مجل جاهلي أو إسلامي أشرف شعره وأجزله، ثم بأتي كمال

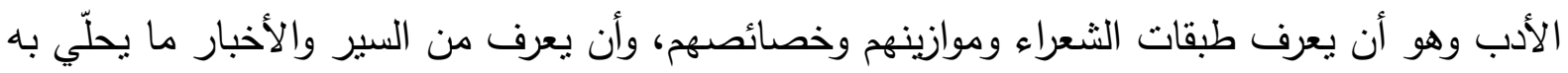

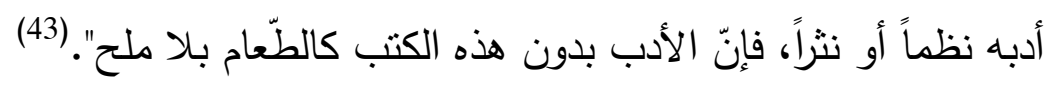

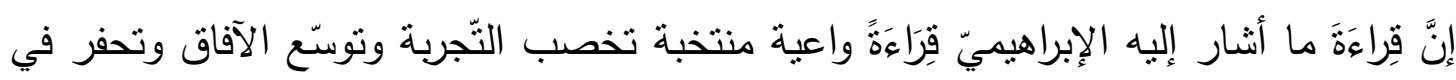

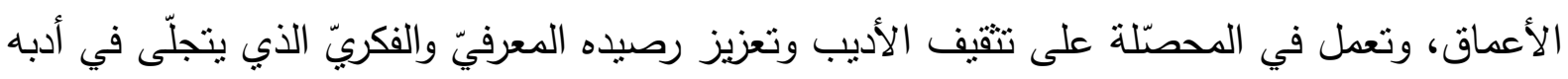

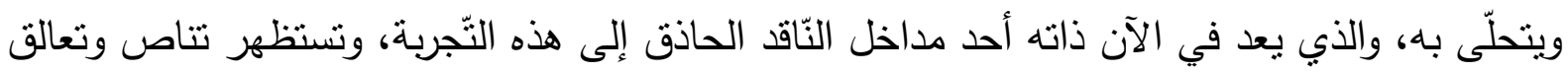

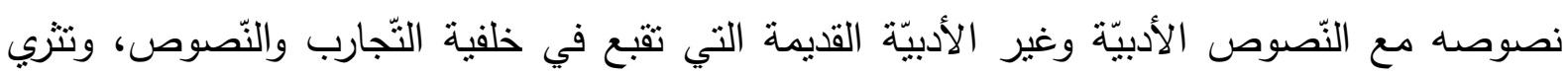
أبعادها الإيحائية اللّامتتاهية.

إنّ هذه الفكرة هي ما يحدّد تجربة الإبراهيميّ كناقد عالم وقارئ خبير ، وهي ما يختزله بالقول:"

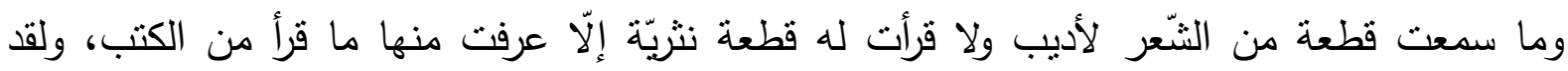
وعكت مرّة فأرسل إلي أديب يسلّيني بقطعة من الثّّر ، منها:

$$
\begin{aligned}
& \text { إذ رماه الدّهر بالضّر ورامه } \\
& \text { أيّها الحـــاكي أبا شبرمه } \\
& \text { ناذرا عتق غلام وغلامه } \\
& \text { ليتتي جئت كيحي عايدا }
\end{aligned}
$$

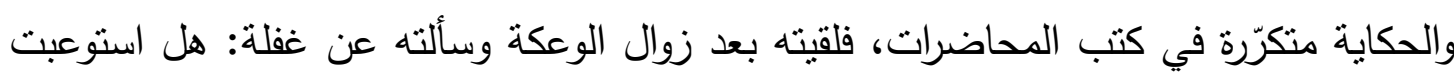

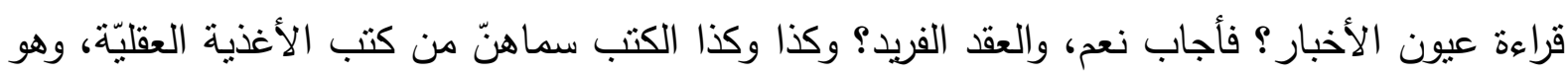

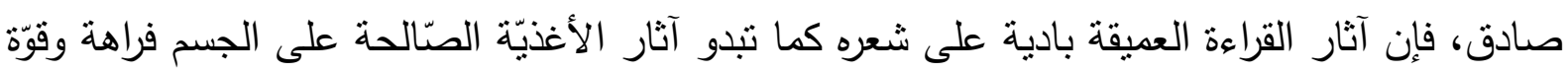
وحيويّة". (44) إنّ تلك الأغذيّة الصّّالحة لبادية في النّصوص الجيّة النيّة حسناً وجمالاً وعمقاً وبعداً.

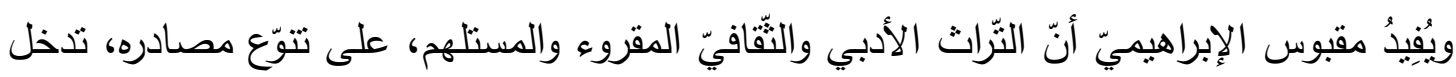

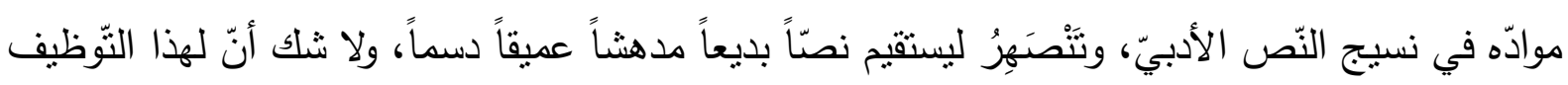

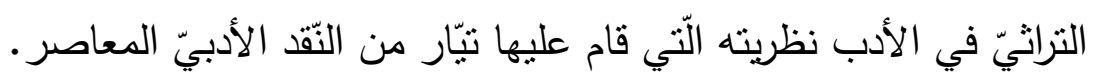

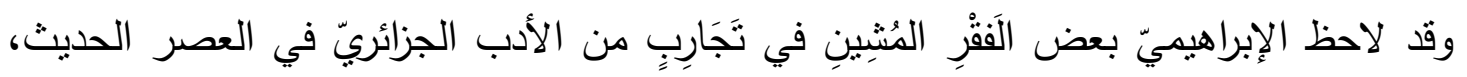

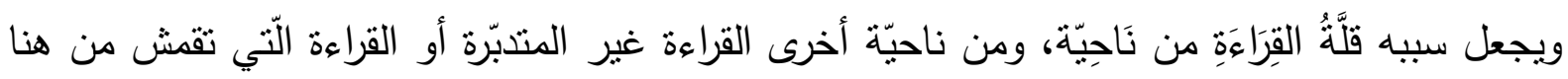

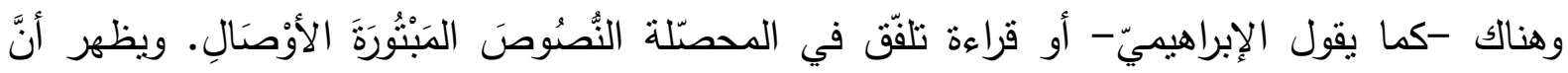

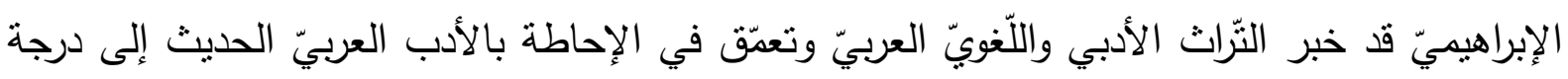

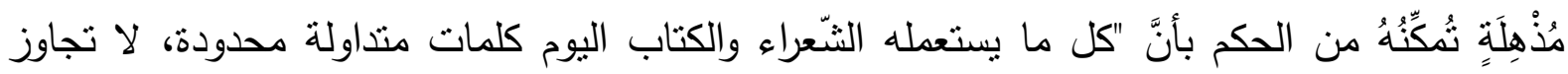


مجموعها خمسة عشر ألف كلمة، وهي بضاعة السّوق، فإذا كانت كافية للاستهلالك اليومي الضّروري،

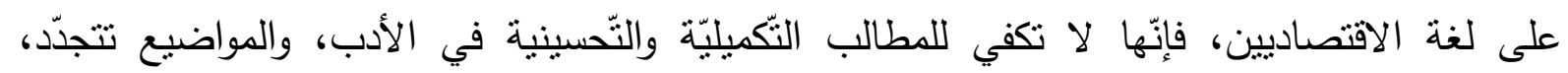
والمعاني تتوارد وتتثابه ثم تتمازج ثم تتمايز، فمن الواجب أن ننحت من هذا المعدن القديم كلّ يوم جوهرة

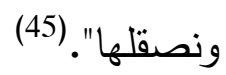
ولا يكتفي الإبراهيميّ بالدّعوة إلى الاستفادة من الرّصيد الهائل للغة والثّّعر، ويدعو إلى الإبداع

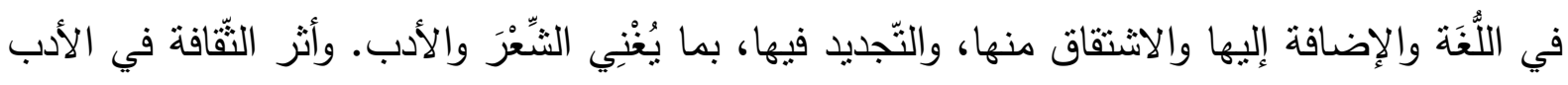
لا تتجاوزه عين النّاقد أو القارئ، وإن خفي ذلك الأثر وذاب في النّصوص. فمنه يزدان النّص ويتميّز الأسلوب، ويَغْنَى الفِكْرُ وينشط الخيال.

وتضيف قراءة الإبراهيميّ لشعر محمد العيد آل خليفة إلى نتائج قراءته المتقدمة ما يلي: - ضرورة انتّام الأدب بالتّفاؤل والإيجابيّة، وهي صفات الإنيّة نتولّد من شخصيّة الأديب، وتتعكس في أدبه. - تعاطف النّاقد والقارئ له قيمة خطيرة في نوجيه الأديب.

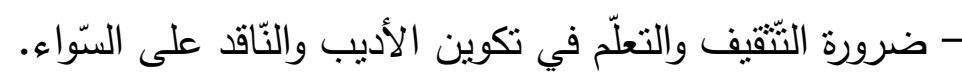
- تجاوز الموجود والموروث إلى الإبداع والخلق والتّجديد.

2.3

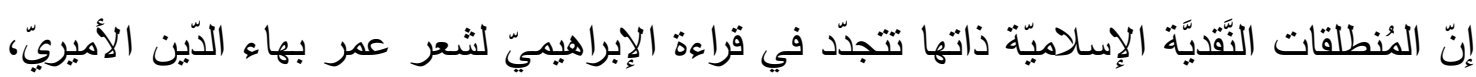

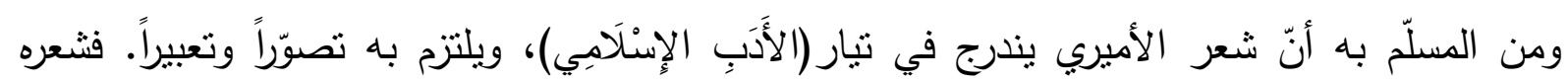

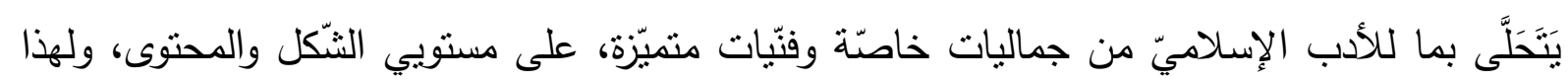

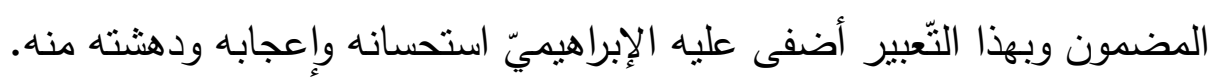

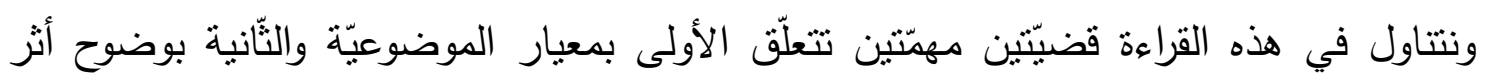

$$
\text { الدّين (الفكرة) في الإبداع الأدبيّ. }
$$

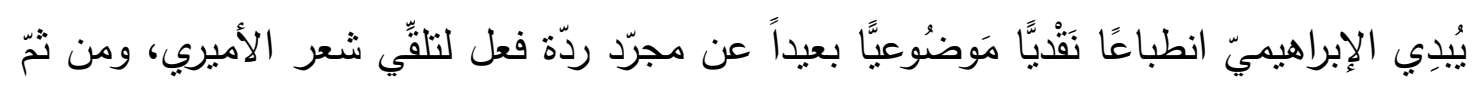

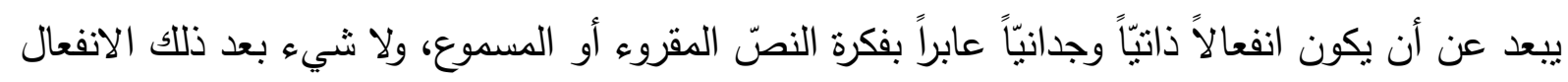

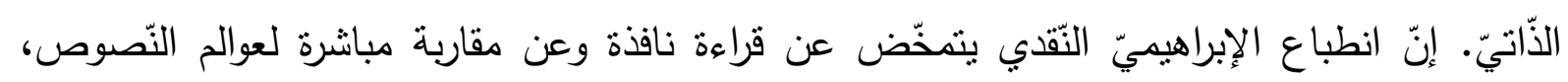

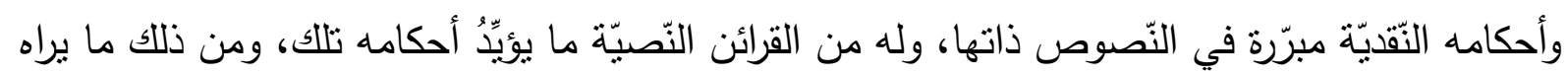

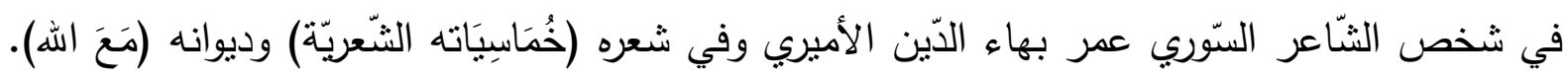

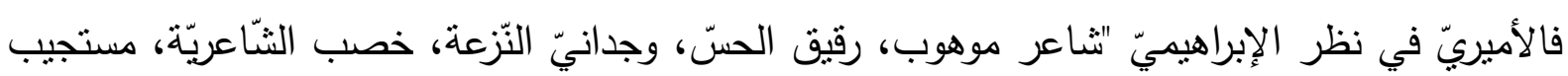

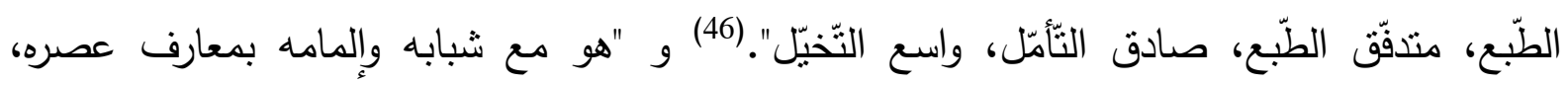

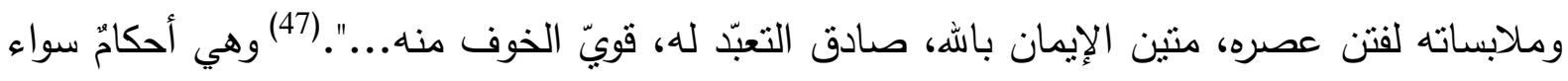


في حقّ الثَّاعر أم في حقّ شعره يخرج بها من بعد قراءة ديوان الثّاعر (مَعَ الله) مع ذللك الإعجاب الَّني

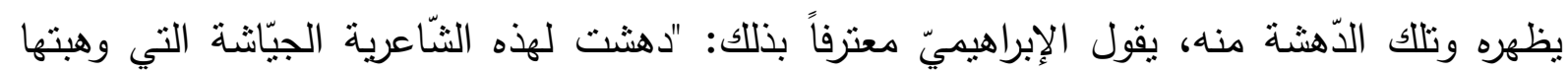

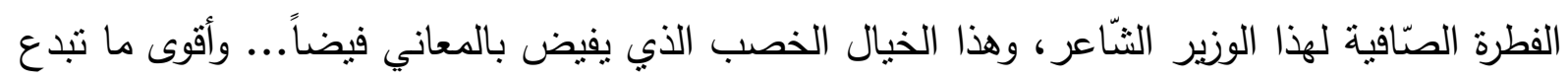
هذه الثّاعرية، فيما لاحظت حين تتّصل نفس شاعرنا باله، وبمجالي آياته في الكون، وبأسرار البشرية

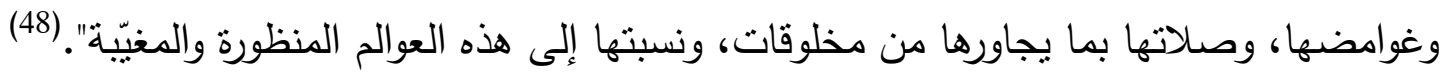

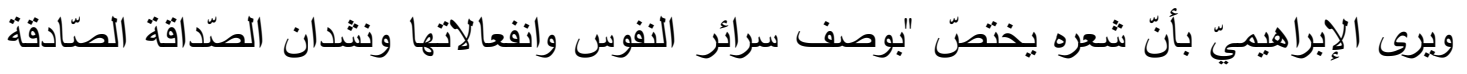

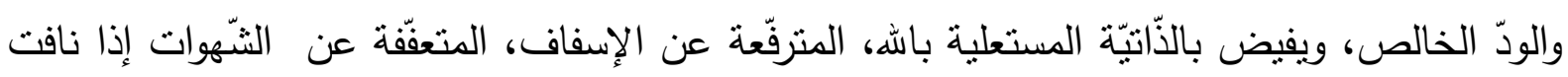
إلى الكمال، أو وققت في الطرّيق إلى الله، ويسمو في كثير من أغراضه إلى سمة الزّرح بخالقها، وترقيها

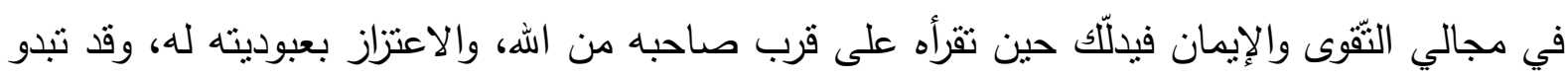

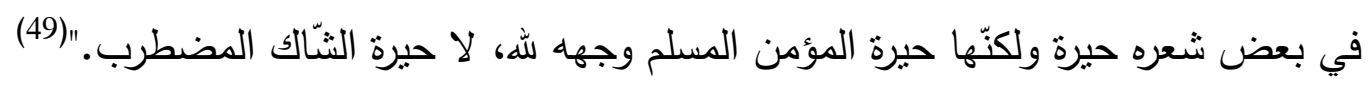

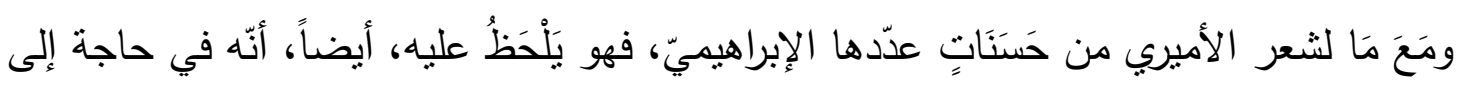

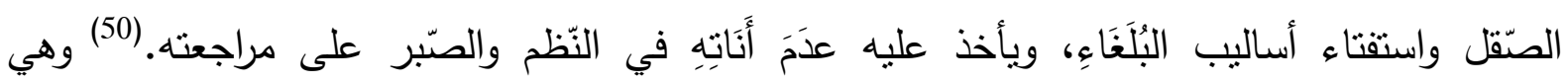

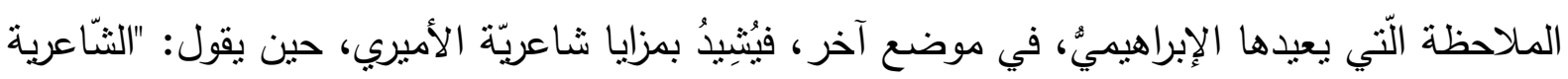

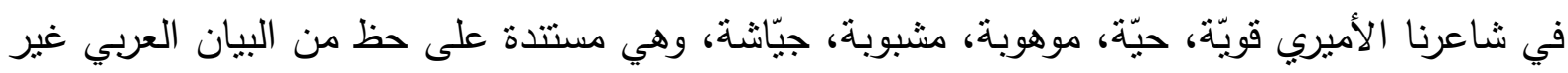

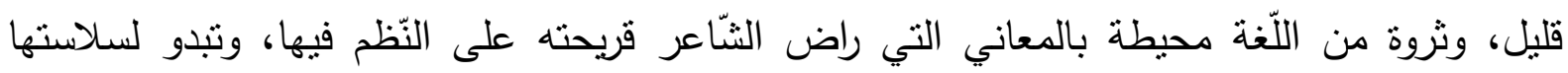

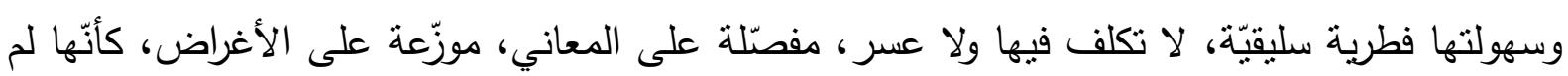

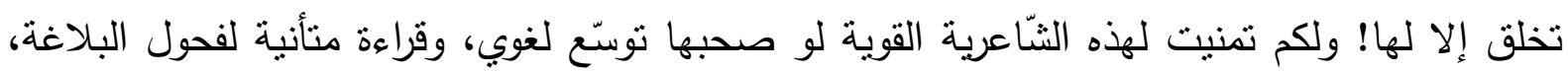

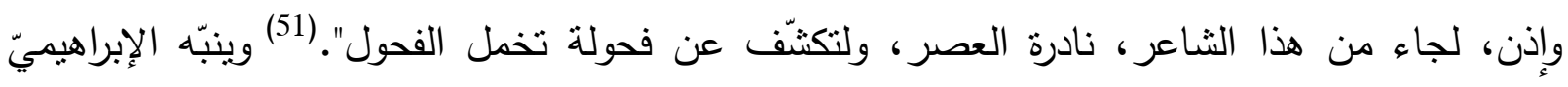

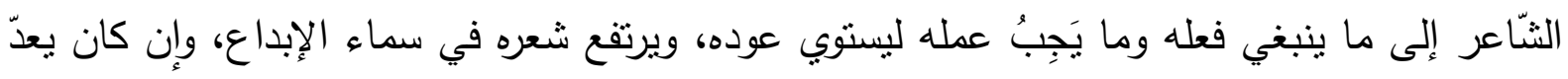

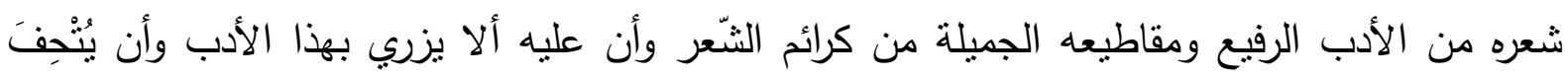
الأدب العربي بنلاك العرائس المخدرة.

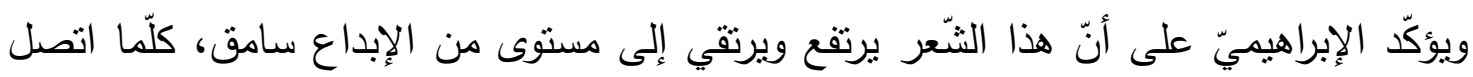

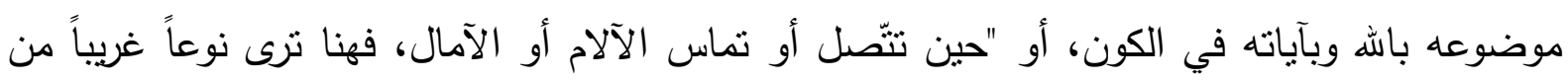

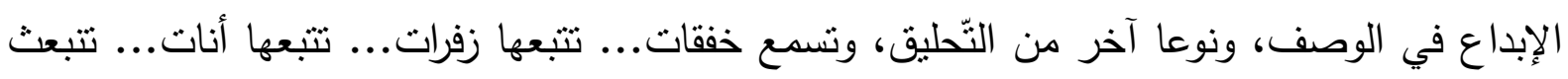
منا آهات... يمزجها الثناعر في مقاطيع صغيرة، من البحور القصيرة، سهلة السبك، سهلة القافية، فتأني

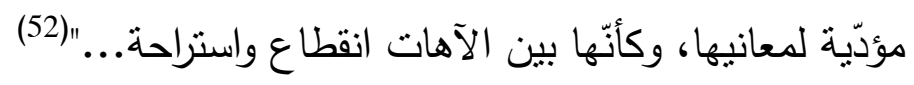

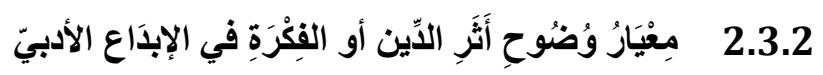

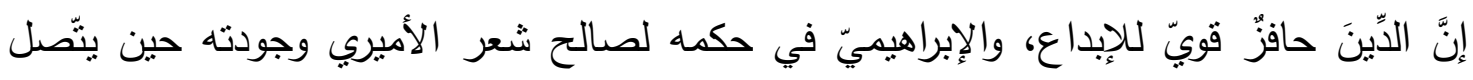

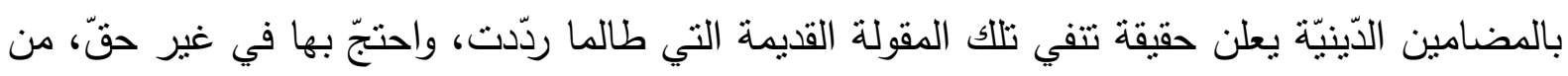


أنّ الثَّعر إذا دخل في الخير أو ارتبط بالإسلام ضَعُفَ ولان....(53 ويرى الإبراهيميّ أنَّ "إِيمان صاحبنا

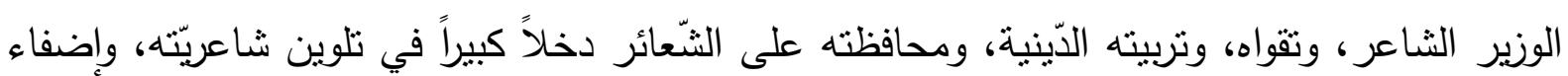

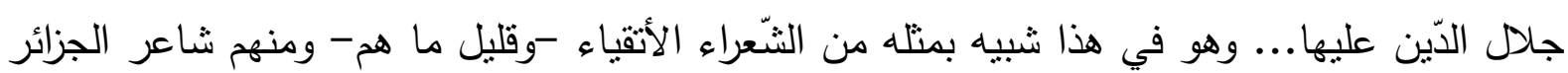

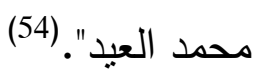

وممّا يزيد شعر الأميري بهاءً وألقا أنّه "لا يتدلّى إلى المعاني الثنّافهة التّي يسفّ إليها أصحاب

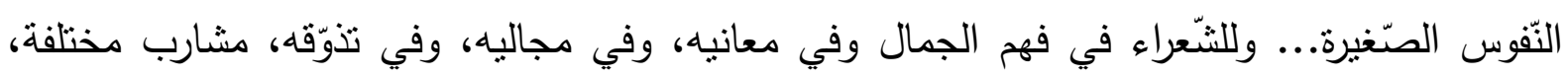

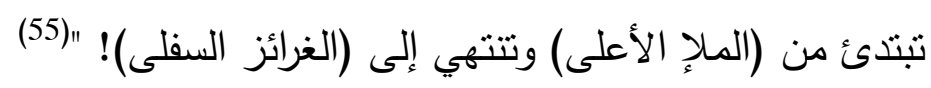
ويمكن التَاكيد على قضيتين مهمّتين في قراءة الإبراهيميّ لشعر الأميريّ: - الأولى تتعلّق بالموضوعية في النّقد فلا ينحاز النّاقد ولا يجامل ويحكم بما يلمسه في مقروئه الثّّريّ، ولا يحابي ويقول رأيه بجرأة ومنتهى الصّراحة.

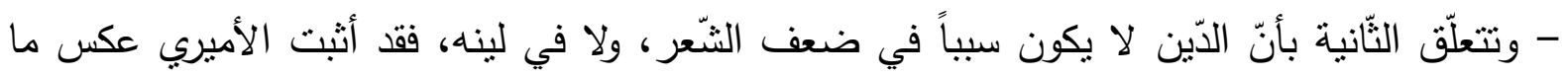

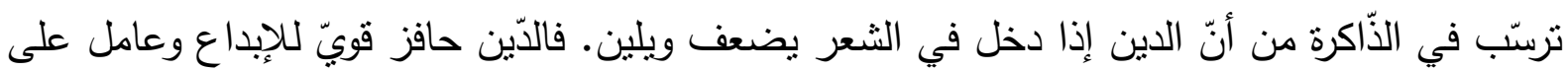

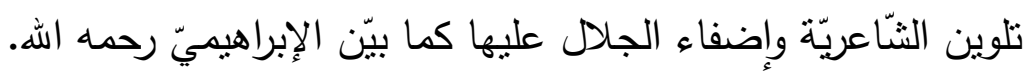
وفي خلاصة هذا المحور، فإنّ اعتماد معيار الموضوعيّة والفنّية في النّقد بعيداً عن الذّاتية، الإبراهي

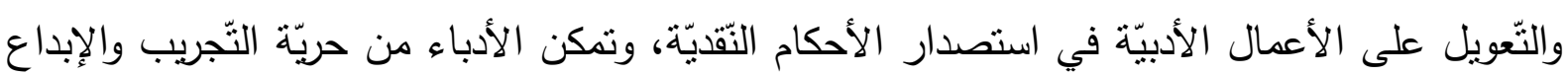

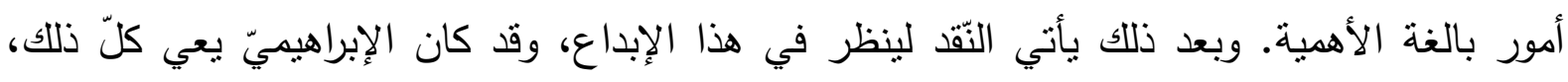

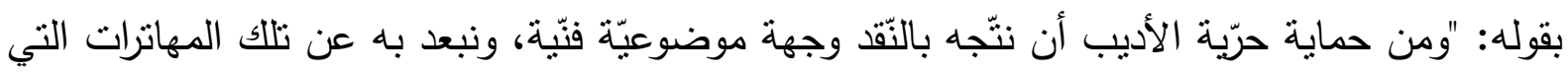

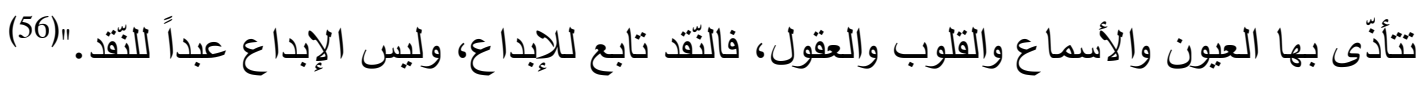

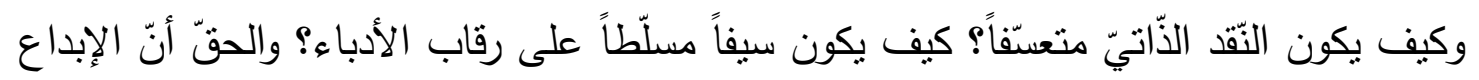

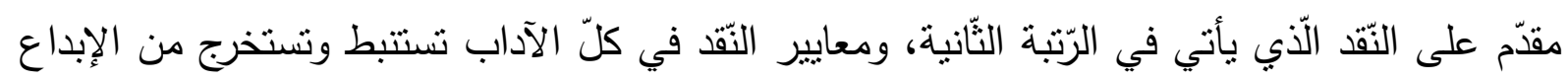
ذاته لتوّجه كلّ إبداع يأتي، ولترسم معالم متجدّدة للأدباء النّاثشئين القادمين.

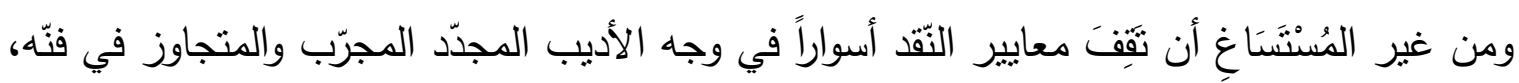

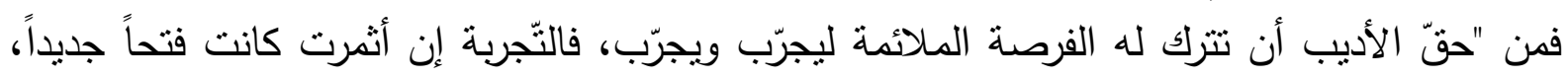

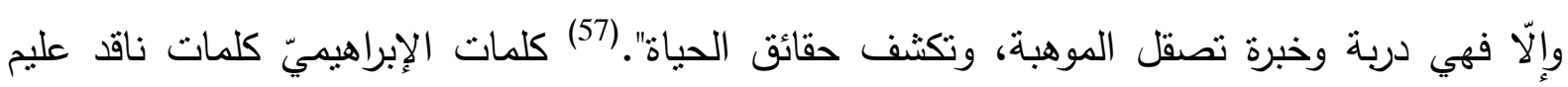

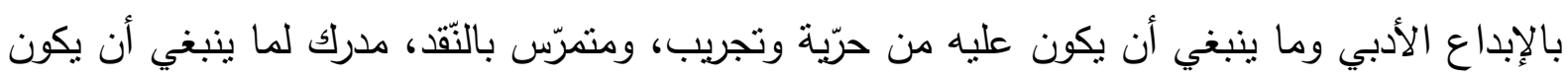

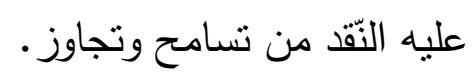

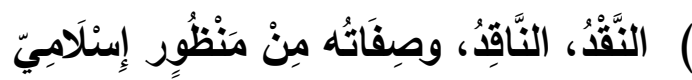

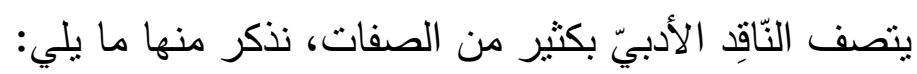


3.1.1 الإنْصَافُ والصَّرَاحَة

يترتبّ، على ما تقدّم مدّا أشثار إليه الإبراهيميّ، أن يتجنّب النّاقد صفة التّّصب والانحياز، وأن يعتدل ويتوسّط في حكمه، وأن يراجع أحكامه النّقديّة وينتبه إلى أخطائه، وأن ينصف في التَّقيهم، ويصارح بالماحظات ولا يجامل الأدباء.

وفي هذا الإطار، أشاد الإبراهيميّ بجودة شعر شوقي فكراً وفنّاً موضوعاً وشكلاً، ونوّه معجباً ببراعته وجمال صناعته وصدق إيمانه وقوّة عقيدته، وبيّن في أكثر من موطن أسباب إعجابه الموضوعيّة

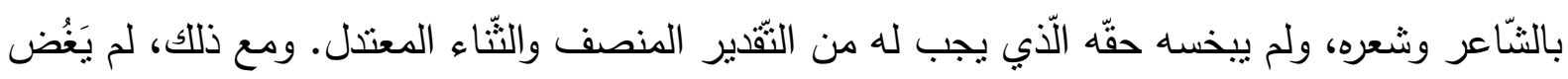
بَصَرَهُ عن هَنَاتِ ليست باليسيرة وهفوات ليست بالقليلة ومَآخِذَ مَعْدُودَةٍ وقع فيها الثَّاعر ، وألَّم بها فتخلّات شعره كما تخلّت شعر بعض السّابقين، وهي ناتجة عن الإفراط والثّريط، معاً، ويقول الإبراهيميّ بهذا الثّأن: "يؤخذ على شوفي أنّه مع جلالته في الإيمان ومتانة العقبدة بطغى عليه الجبروت الثّعري فيقع في هفوات تدخل في باب الإغراق والغلوّ أو في باب التّساهل والاستخفاف، وقد سبقه إلى الوقوع في

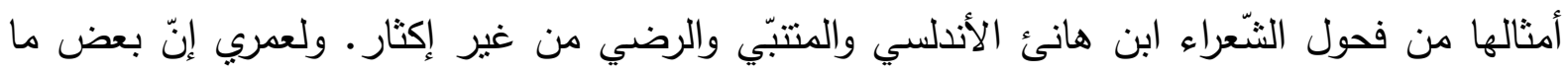
وقع لشوقي من ذلك يجاوز حدود التأوّل، لا لأنّ موقع هذه الأشياء التي تساهل فيها شوقي في باب آن التوفيقيات، وللتوفيقيات في الإسلام آداب مخصوصة وموارد منصوصة لا يستمح فيها، ولا يثفع فيه

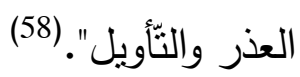

ويسمّي الإبراهيميّ تللك الهفوات بالمُبَالَغَاتِ وسببها الاستسلام للجَبَرُوت الثَّعريّ، وعنفوانه وهيمنته منها، ورد في أبيات ذكر منها قوله:

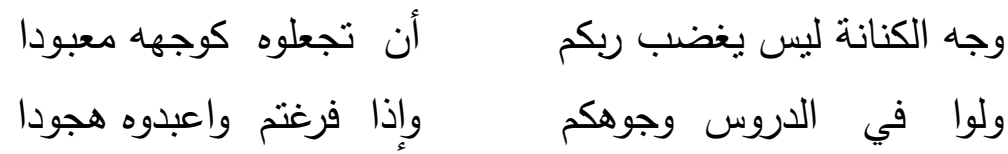

وقوله:

جعلنا مصر ملة ذي الجلال آلفنا الصليب على الهلال

وقوله:

مهرجان طوف الهادي به ومشى بين يديه جبريل

وقوله:

وقفي الهودج فينا سـاعة نتـاوب والرّوح الأمين

وغير هذا في شعره كثير ، وإنها لهنات، نرجو أن نكون في مقابل إحسان شوقي وفي جانب عفو

الله هينات (59). 


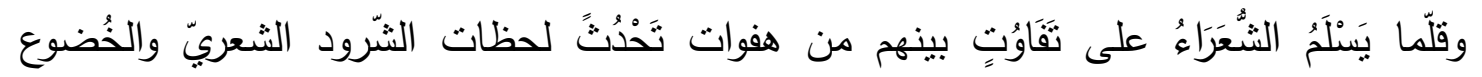

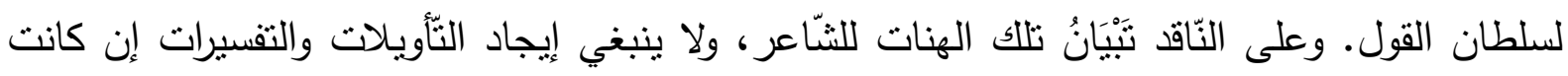
تتجاوز حدود النّأويل.

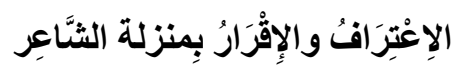

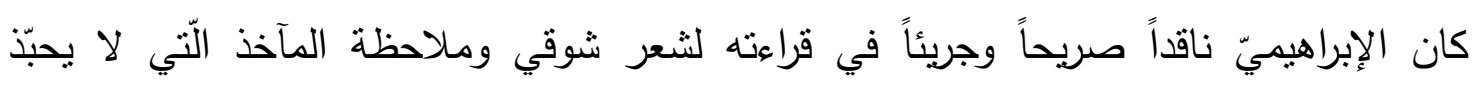

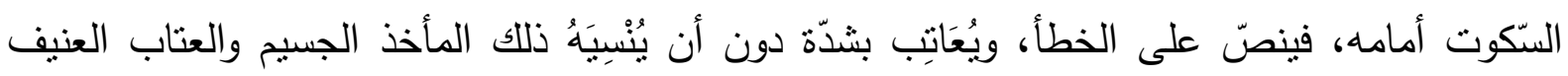

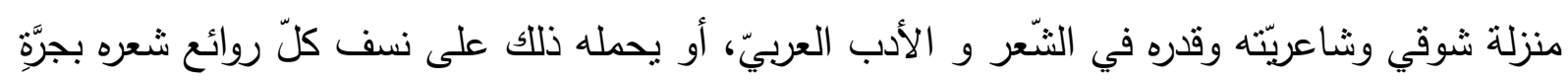

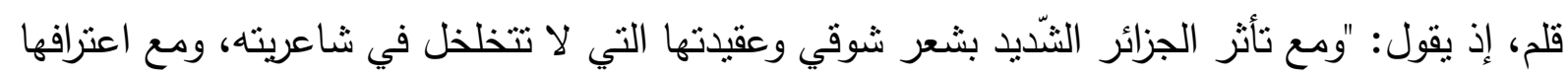

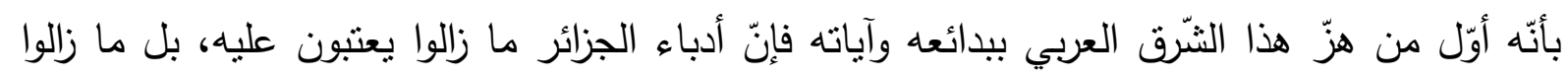

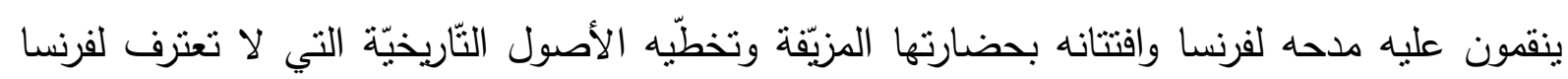
ببعض ما ينوّه به شوقي من فضائلها، فهو يقول: وتعلم أنّه نور وحق

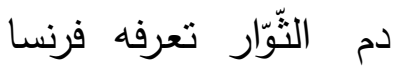

كنهل الستماء وفيه رزق

فكيف على قناها تسنرق؟ جرى في أرضها، فيه حياة وحرّرت الثُّعوب على قناها

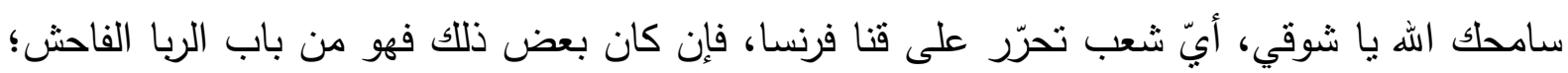

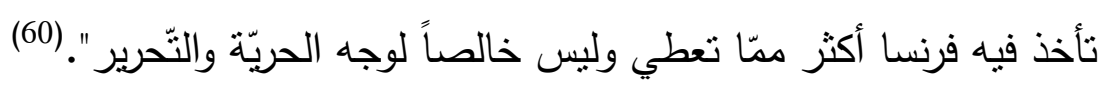

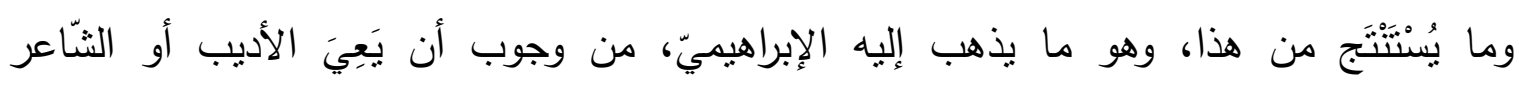

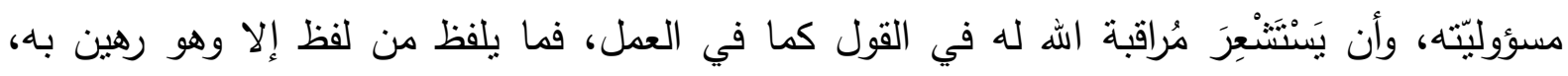

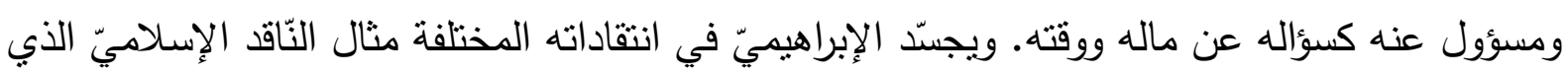

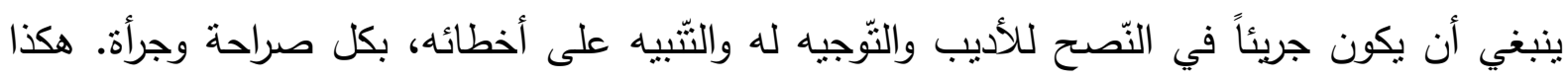
نظر الإبراهيميّ إلى شعر شوقي من منظار إسلاميّ، ووزنه بميزان عَقَّيّ، وغربله بغربال فكريّ، ومرّره

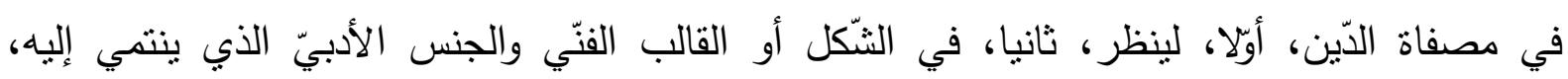

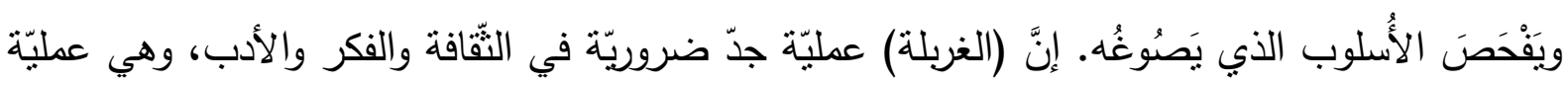

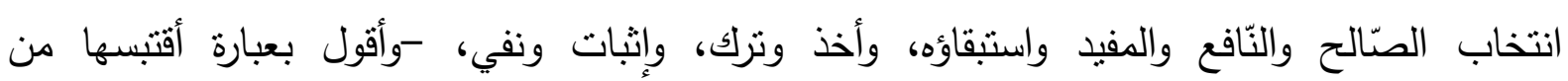

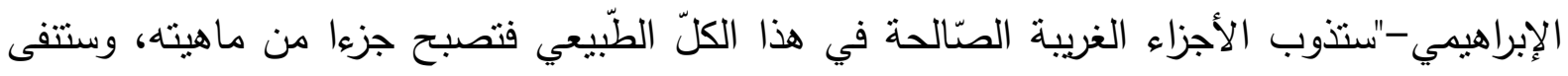

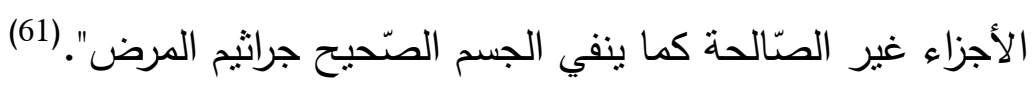




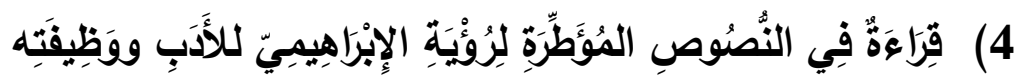

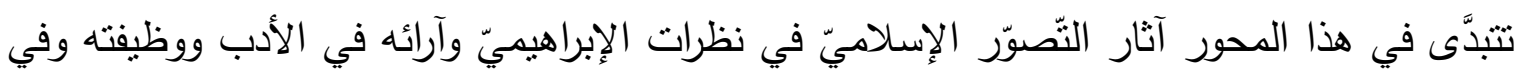
الأديب وثقافته، وهو ما نتتاوله بإجمال غَيْر مُخلّ.

\section{1}

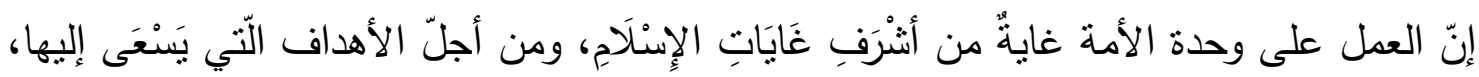

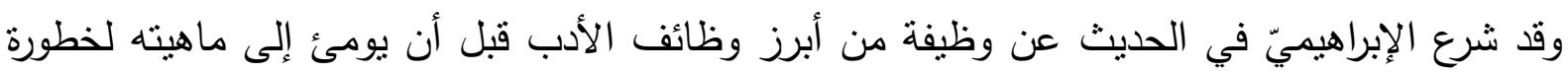

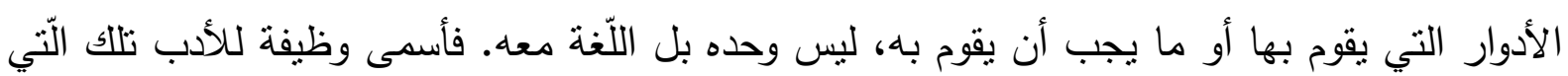

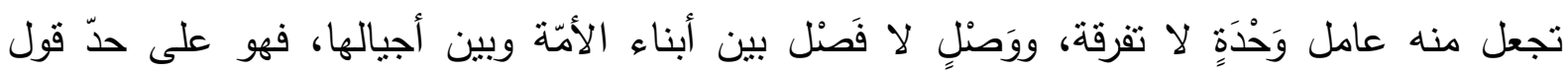
الإبراهيميّ "الوشيجة القويّة والوثيقة الباقيّة التي لم تتقطع طوال القيّة القرون وعبر الأزمان. فهذه هي الأيام

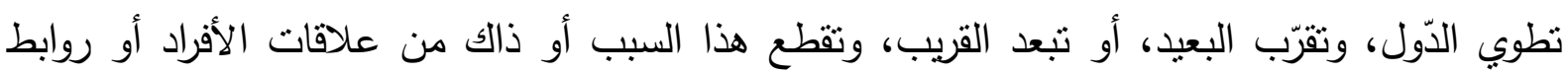

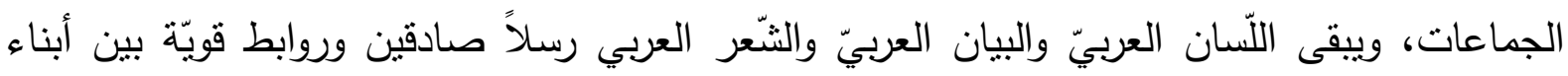

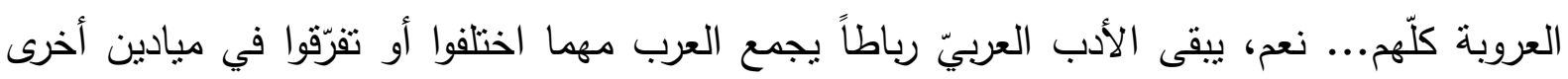
بطارئ من طوارئ الهمّ، أو لون من ألوان الاختلاف في الهمم...." (62)

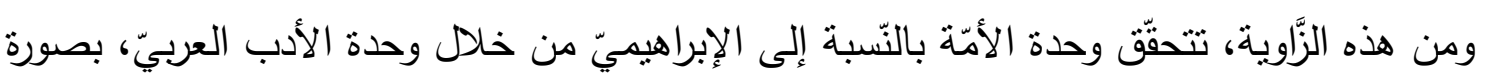

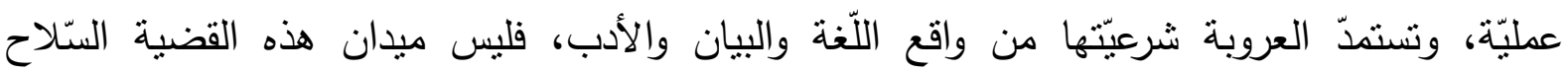

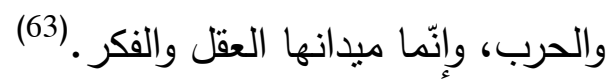

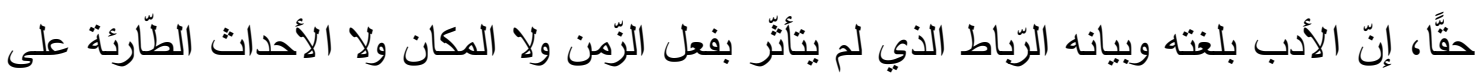

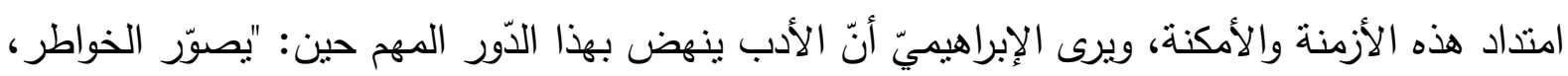

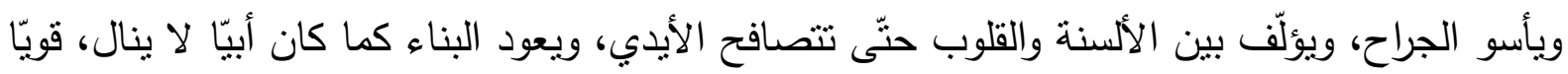

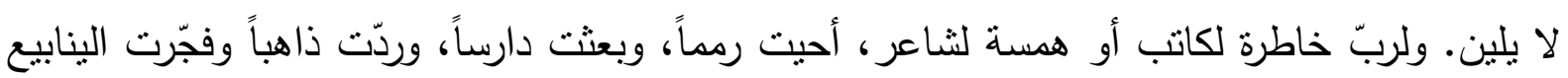

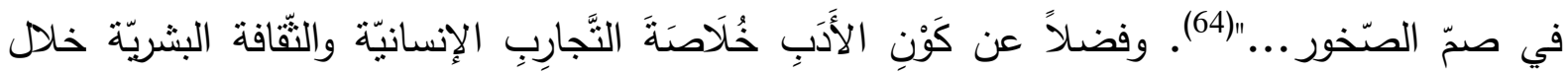

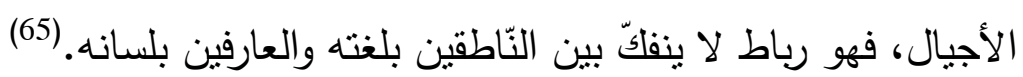
ويُضِيفُ الإبراهيميّ إلى تلك الوظيفة وظيفة جليلة أخرى ودوراً بارزاً آخر لا بقلَ أهميَّةً عن الدَّور

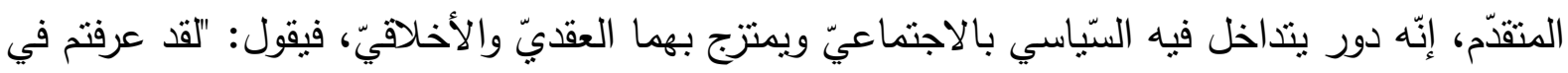

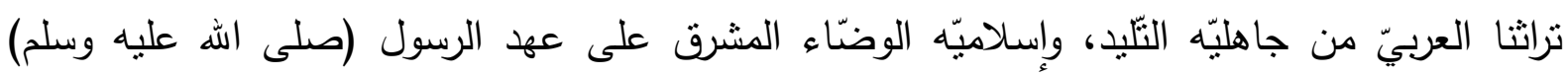

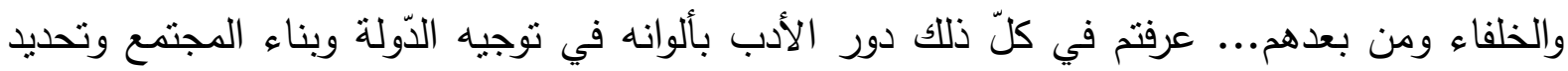

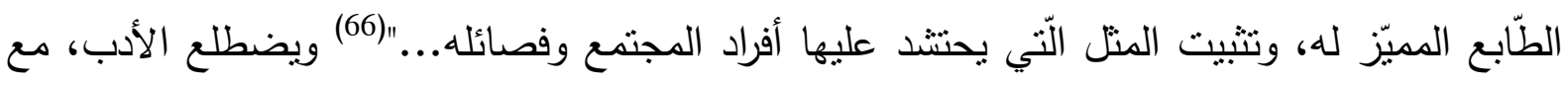
ذللك، بمهمّة المحافظة على هويّة الأمّة وخصوصيّة المجتمع، وهو خير مرآة لانتماءاتها الثقافيّة والفكريّة. 
إنّ الأدب الّّي يتحدّث عنه الإبراهيميّ هو الأدبُ الإسلاميّ البنّاء الهادف الذي رسم طريقه وحدّد

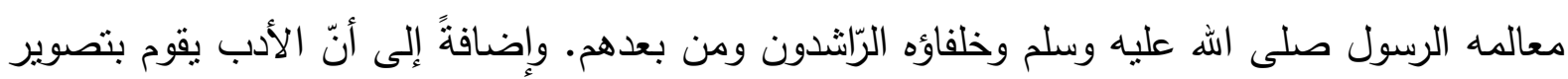

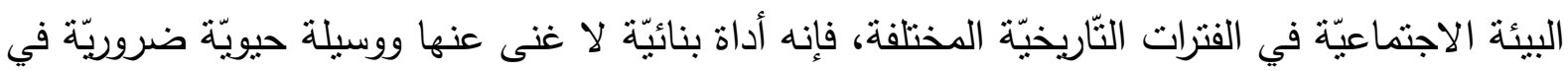

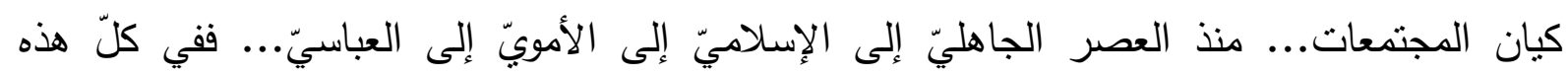

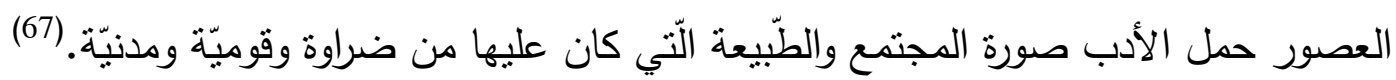

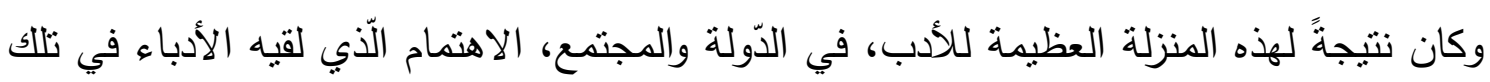

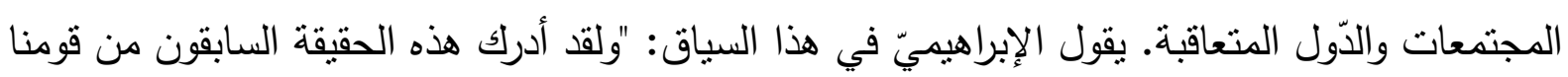

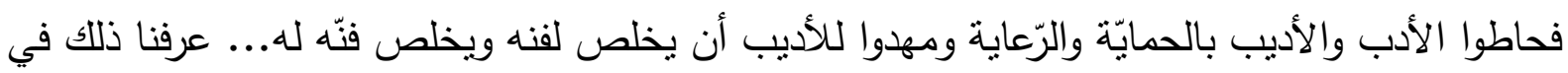

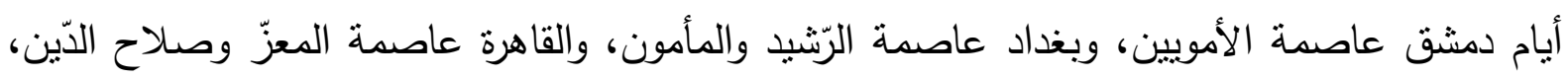

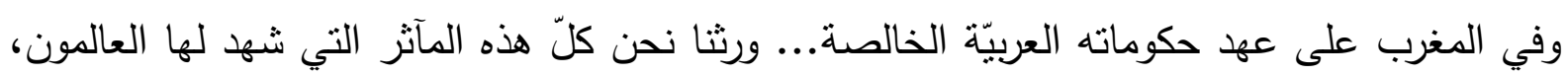
ودان لعظمتها الأوائل والأواخر ". (68)

\section{2}

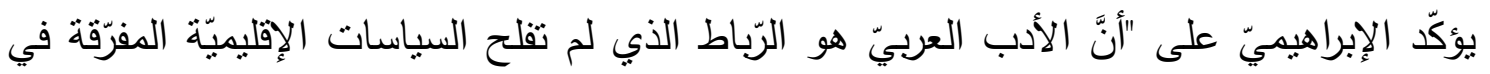

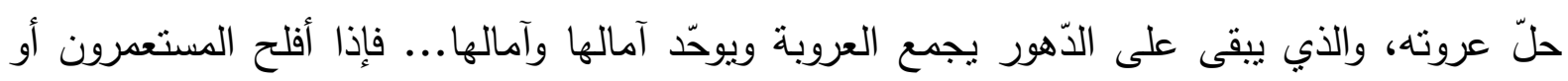

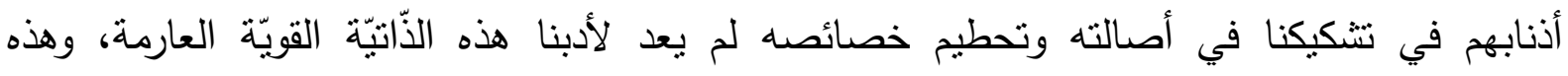

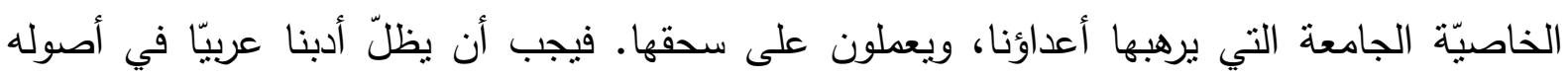

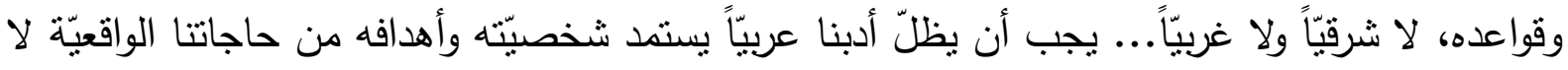

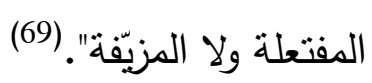

أمّا الأديب فإنَّه لا يستحقّ وصفه ولا ينطبق عليه إلّا إذا تجسّدت في شخصيّته شروط يلمح إليها

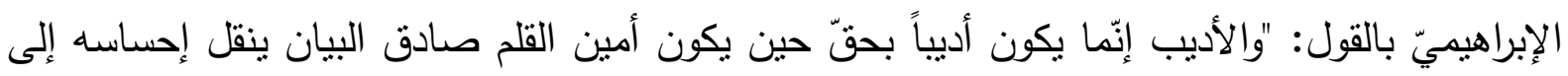

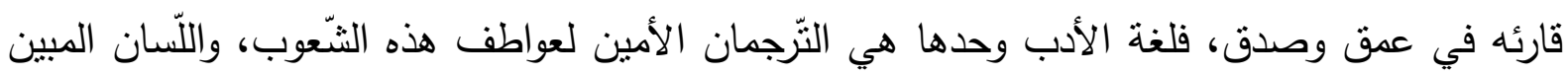

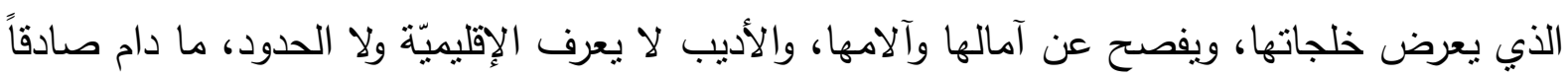

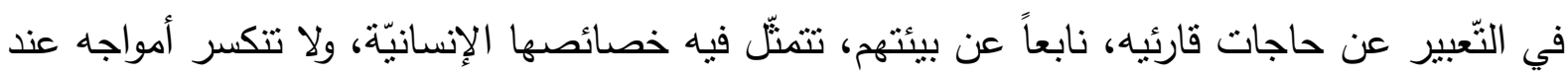

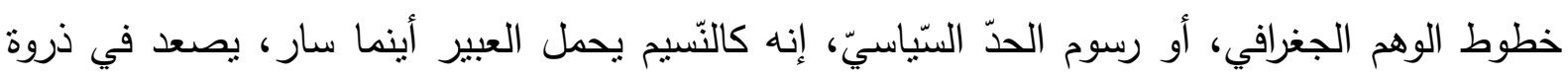

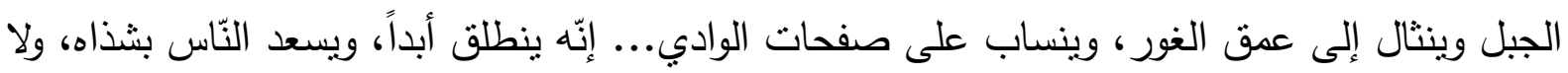

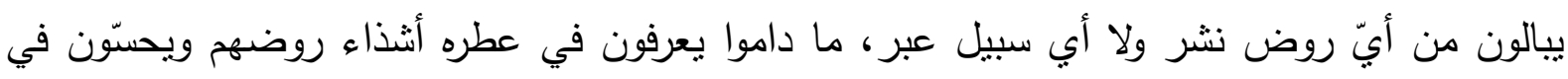

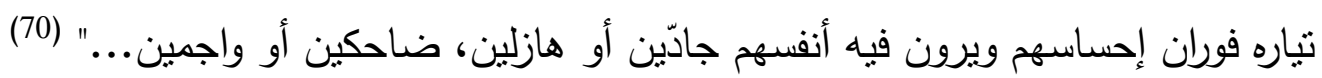

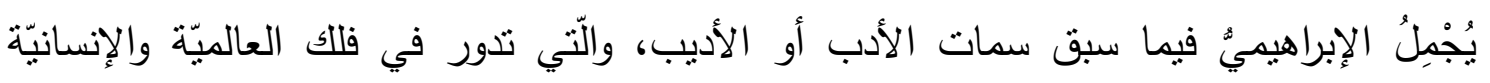

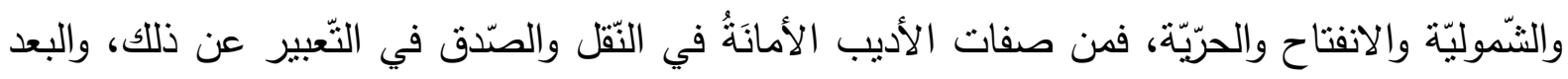


عن التّّيبف والتّخريف والنّفاق والمراوغة، والنَّاي عن التّعصّب والتّحيز بأيّ شكل كان، والوعي وتمتّل

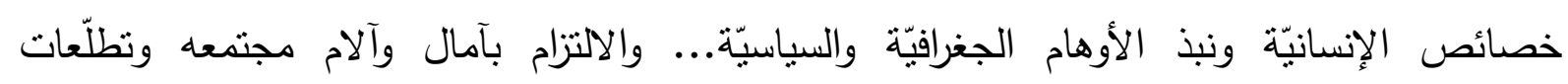

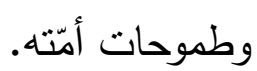

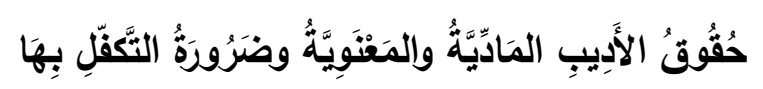

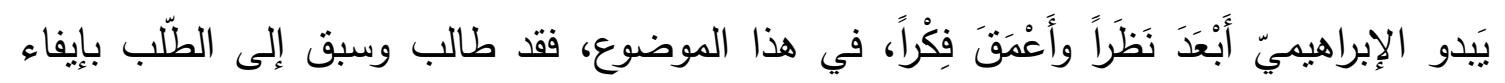

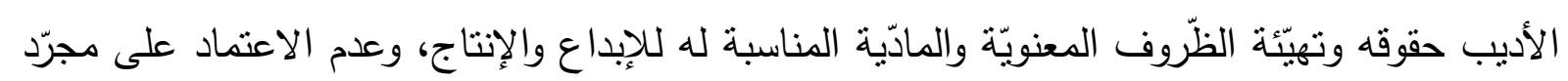

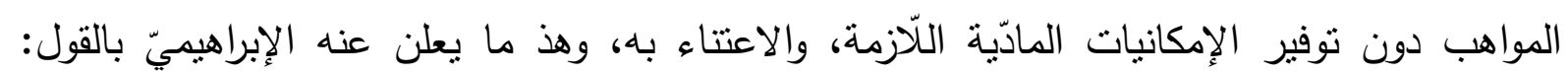

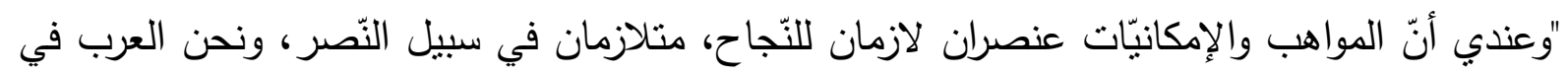

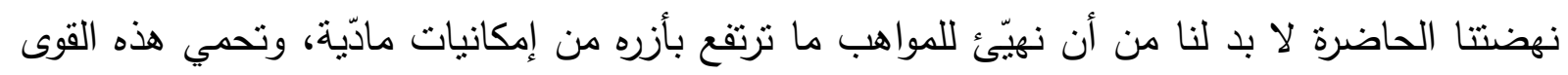

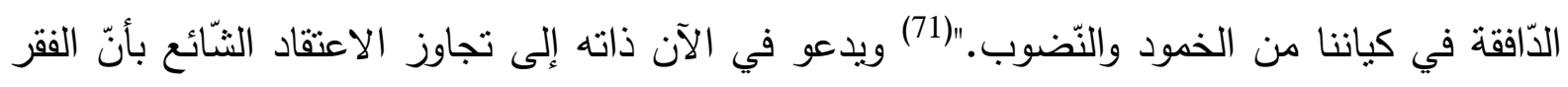

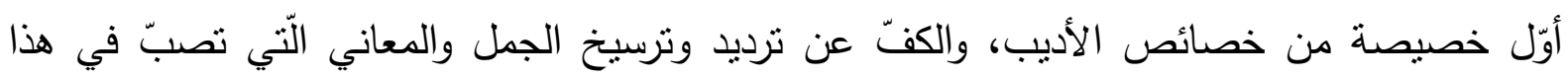

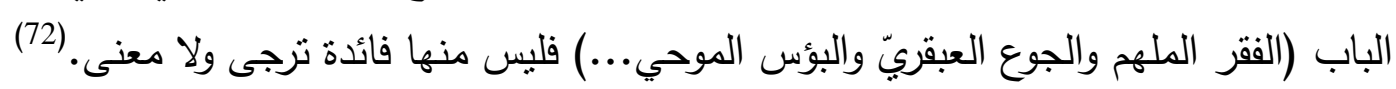

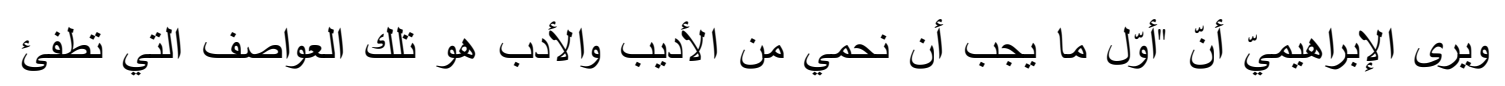

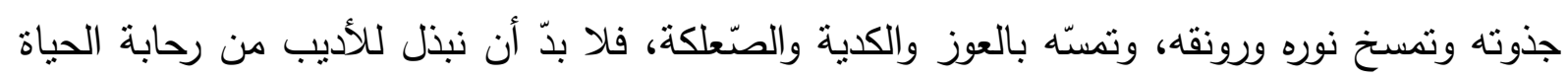

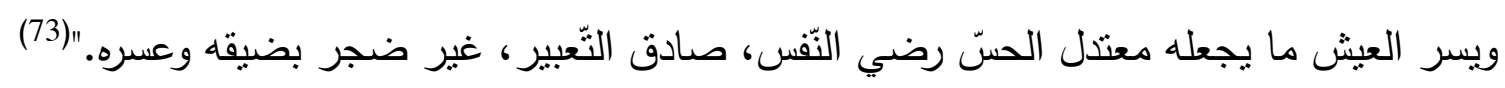

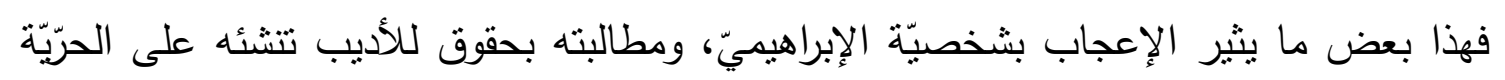

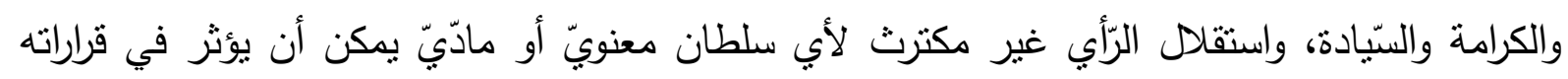
وتوجّهاته، فيزيّف الحقائق، ويذيع الأكاذيب وينشر الأباطيل ويشوّه سمعة الأدب والأدباء.

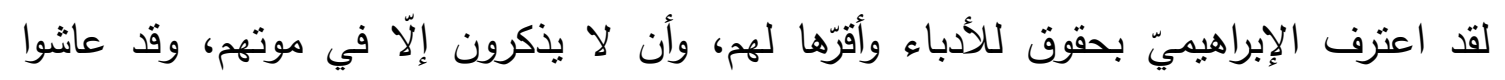

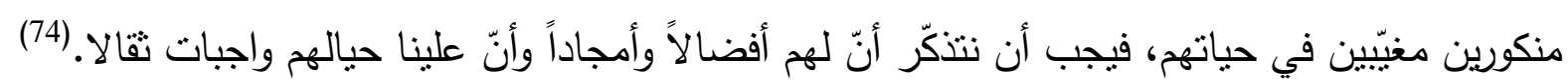

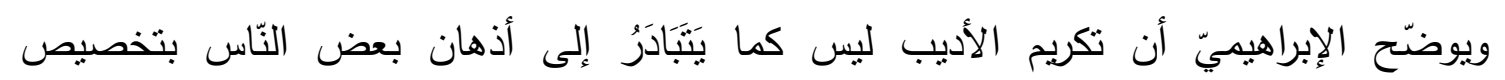

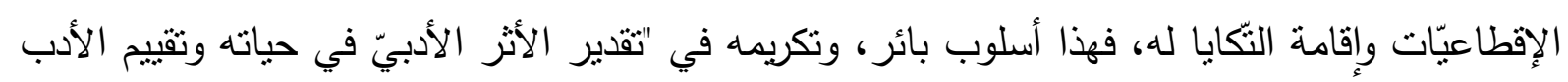

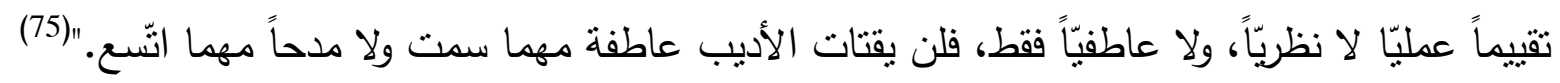

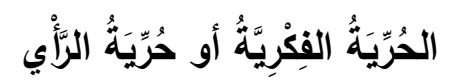

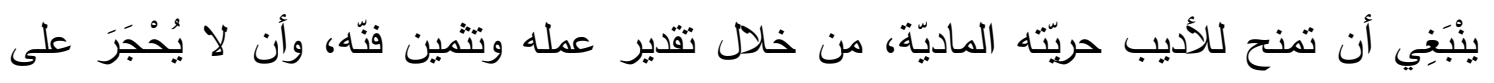

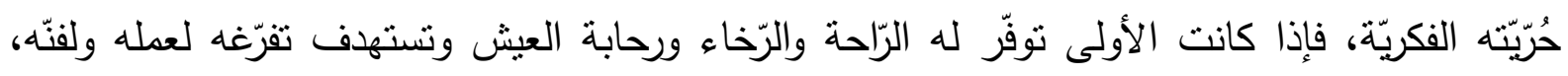

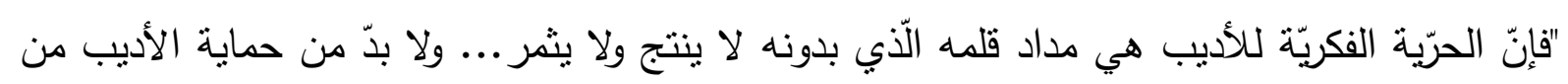

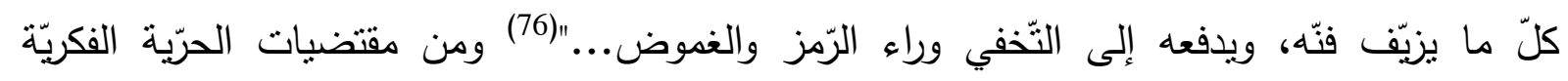
للأديب، كما برى الإبراهيميّ، ضمان النّّد الموضوعيّ لعمله، بقوله "من حماية حرّية الأديب أن نتّهه 
بالنّقد وجهة موضوعيّة فنّّة، ونبعد به عن نلاك المهاترات التّي تتأذّى بها العيون والأسماع والقلوب

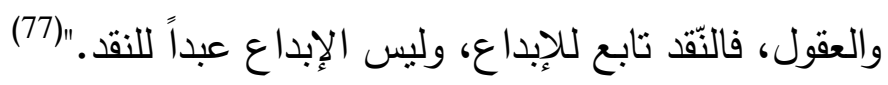

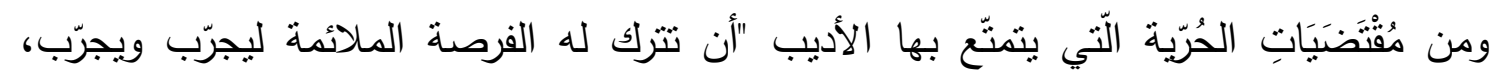

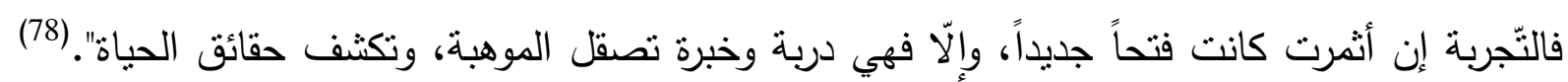

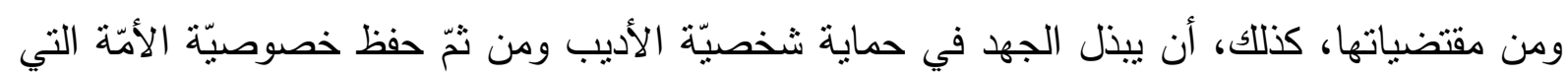

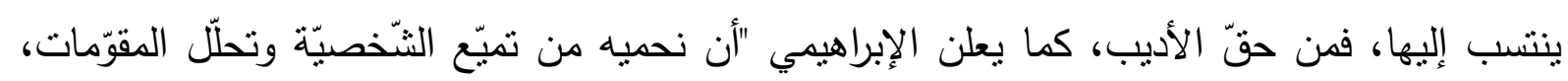

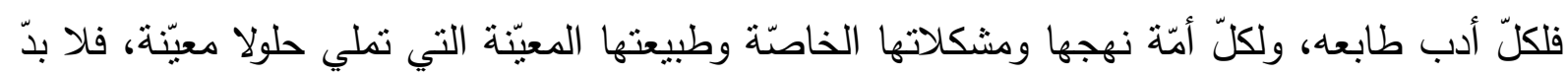

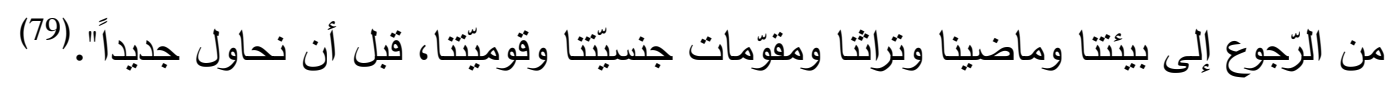

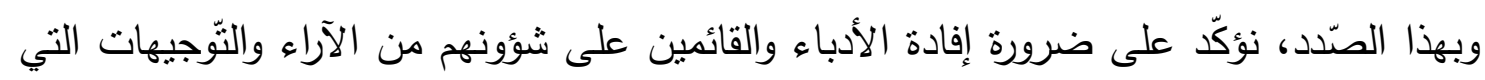

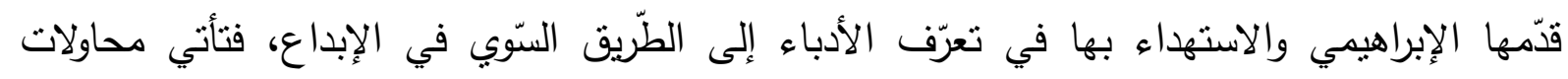

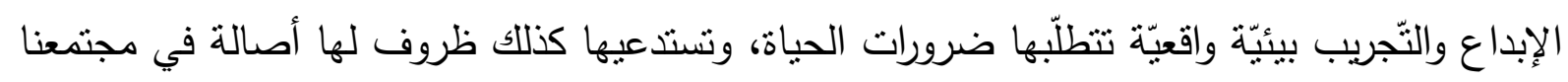

ووشائج بعروبتتا وماضبنا. (80)

4.5

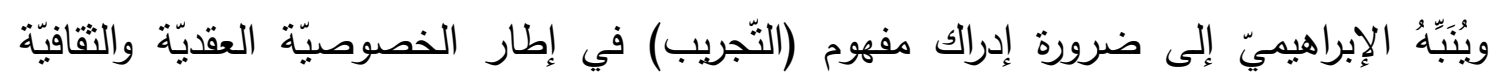

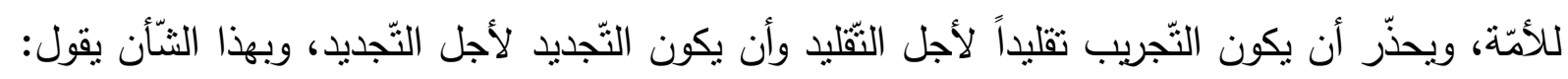

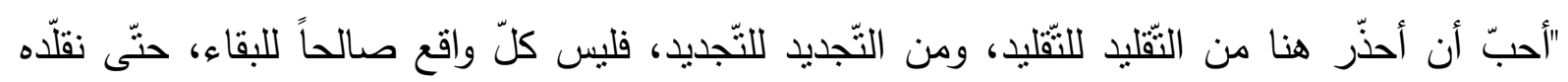

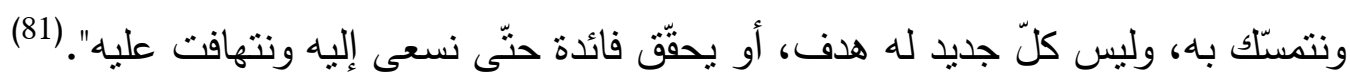

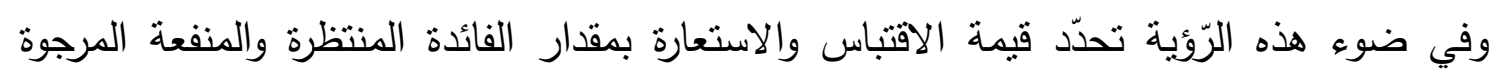

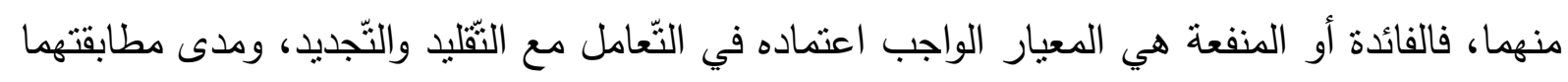

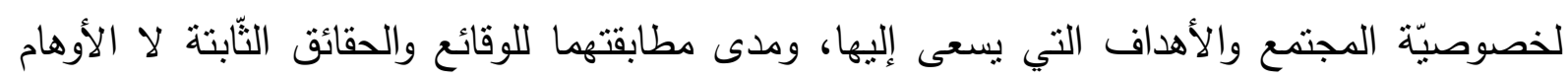
والحقائق الزائفة.

إنّ الأدب أحد المجالات الخطيرة والمهمّة بما فيه من تجريب في الإبداع وإيجابيّة في التقبيم التّي

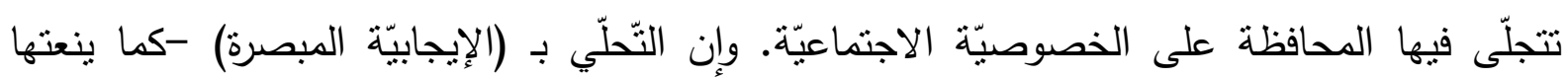

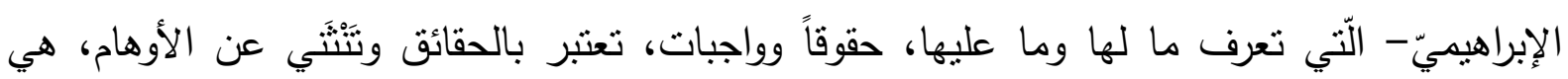

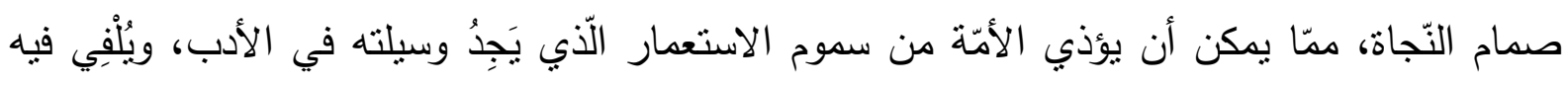

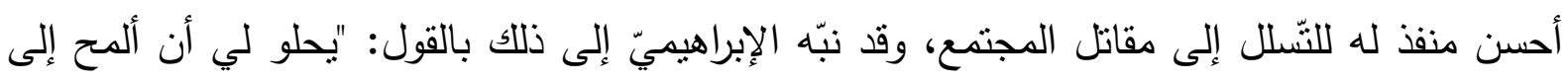

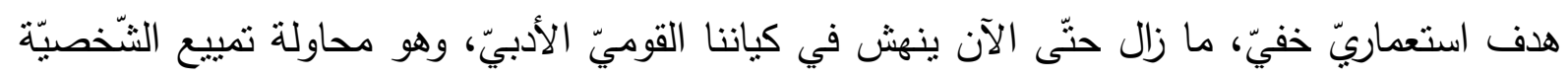

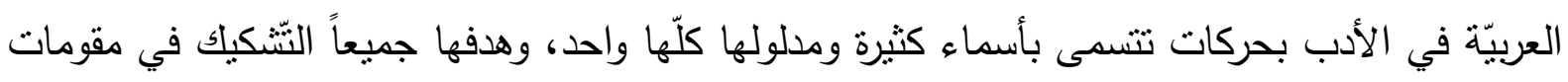
الأدب العربيّ ومحو خصائصده وهدم بنيانه من القواعد".(82) 


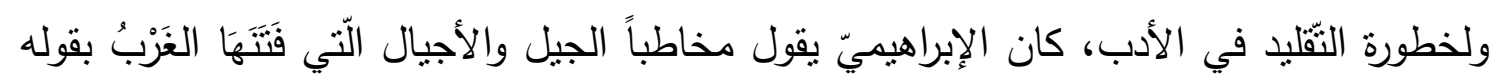

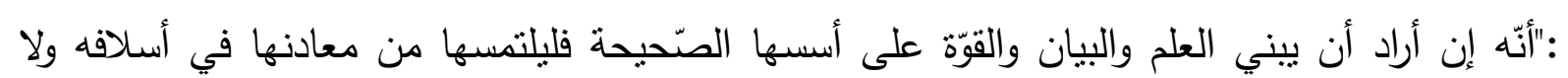

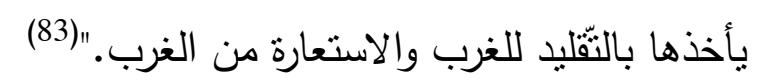
4.6

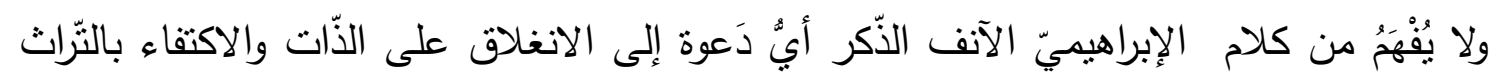

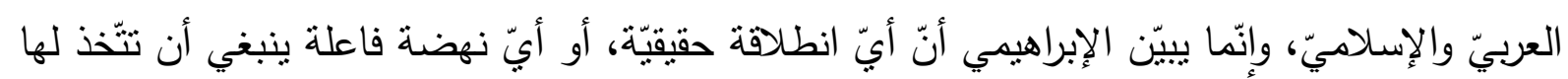

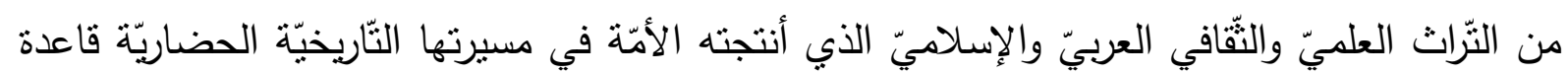

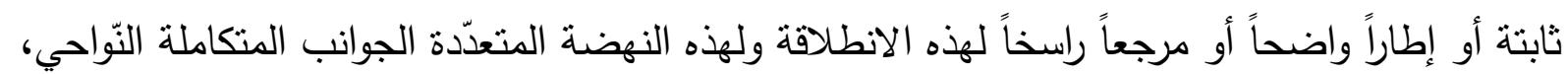

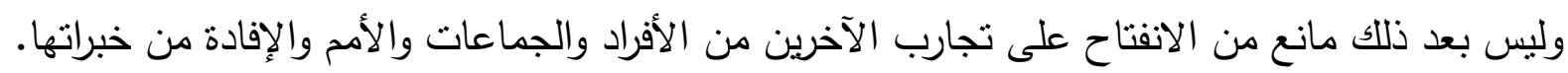

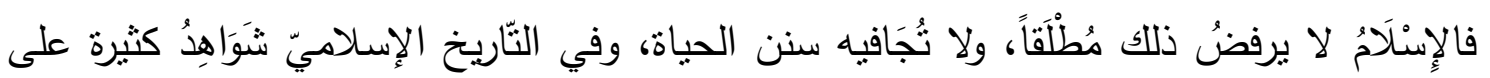

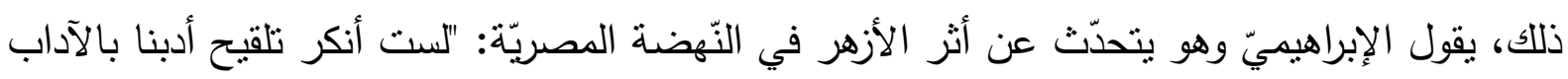

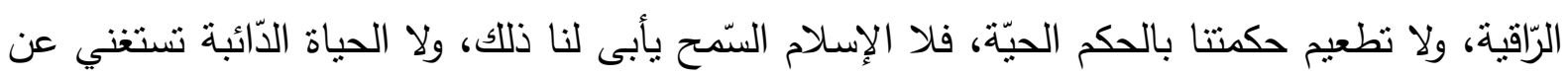

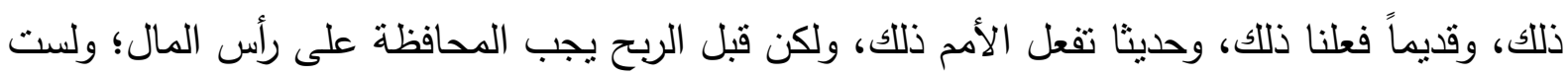

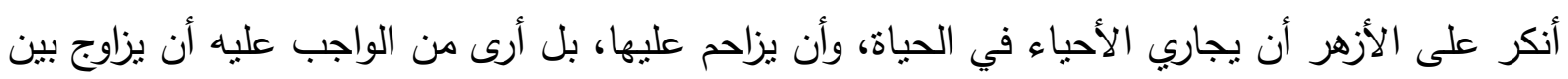

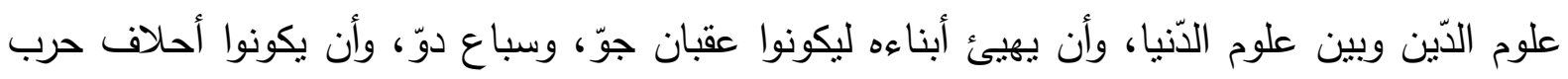

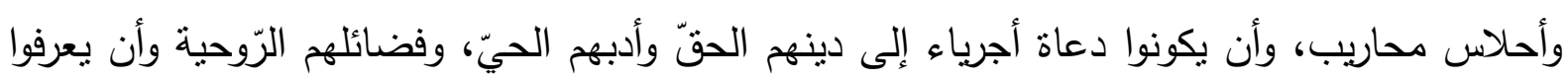

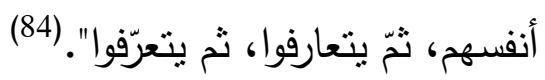

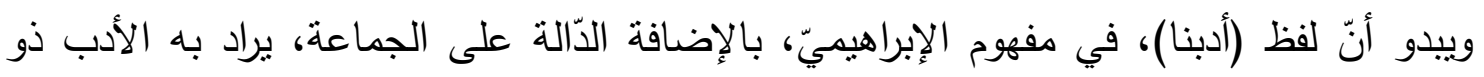

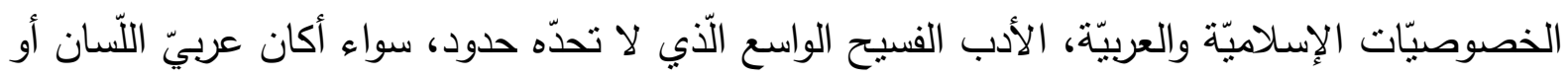

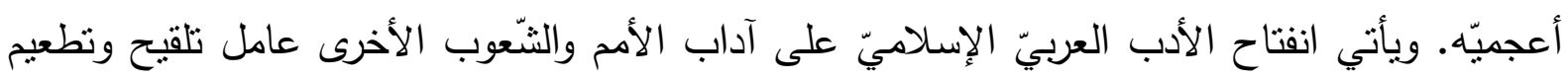

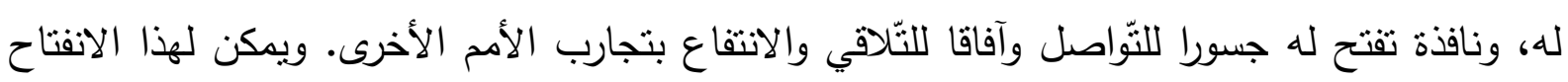

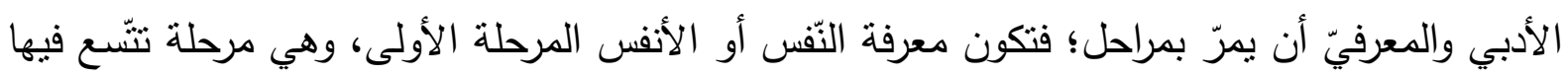

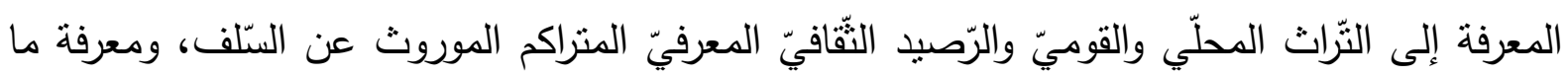

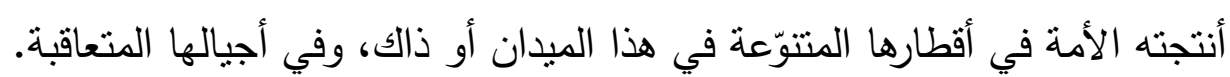

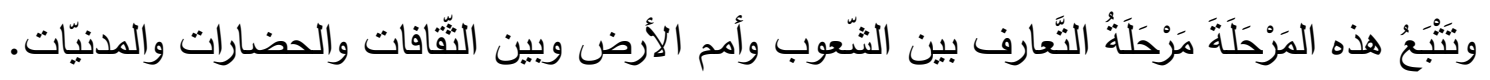
وتأتي بعد ذلك مرحلة (النّّرّف) وهي قمة هذه المراحل حيث تحتلّ الأمّة الإسلاميّة مركز الصّدارة

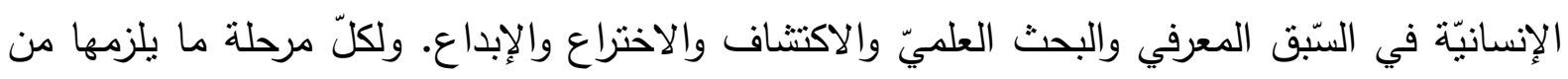

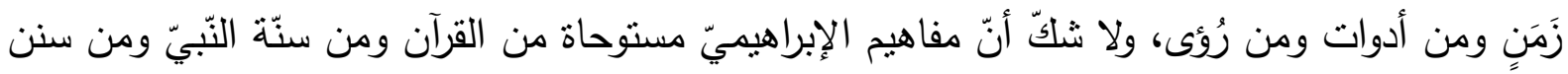


لقد نادى الإبراهيميّ، منذ زمن مبكّر ، إلى حماية حقوق الأديب وحماية إنتاجه من استغلال المستغلّين وسرقات المنتهبين. (85)

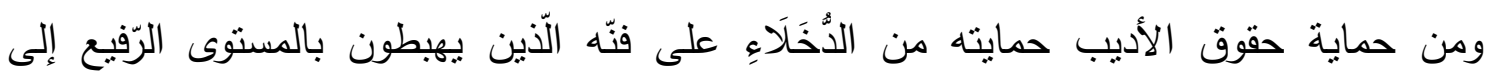

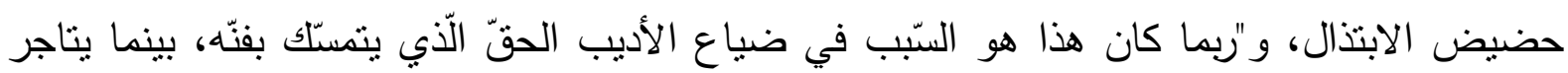

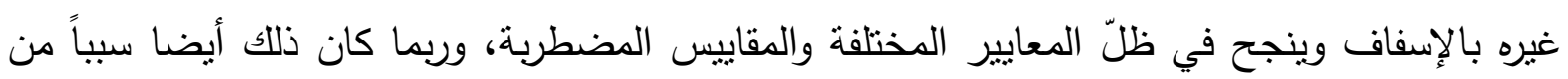

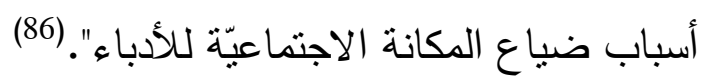

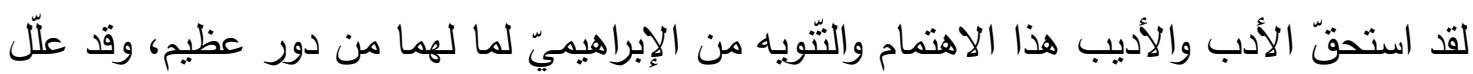
ذللك في هذه الكلمة الجامعة، في قوله: "يجب أن نعلم أنّ خلاصة التقافة والفكر تتمثّل في الإنتاج

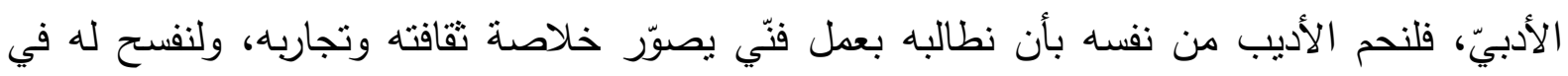

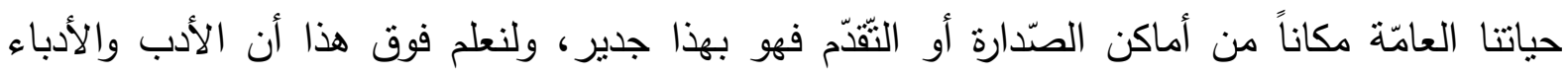

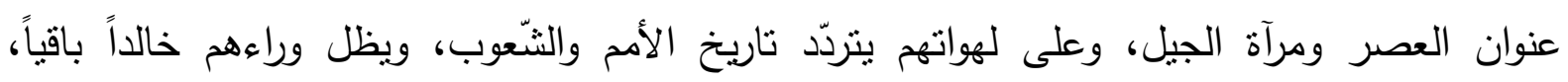

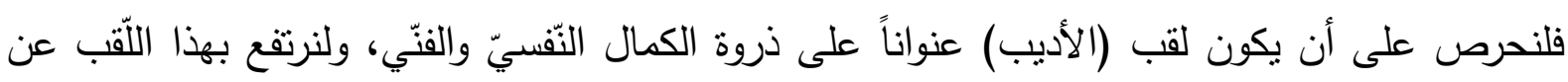

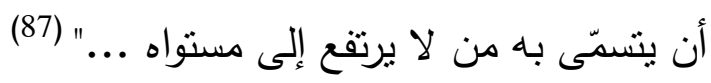

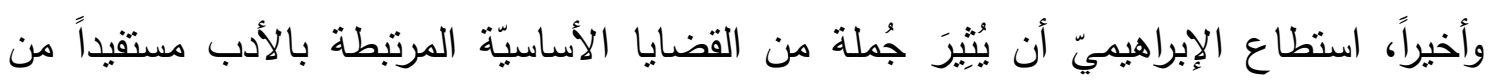

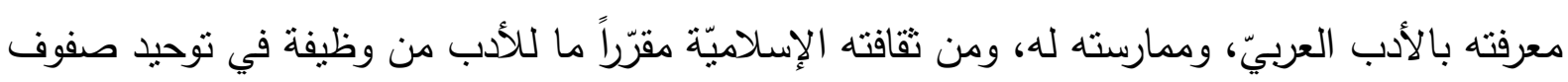

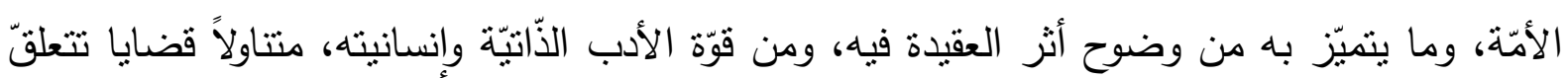

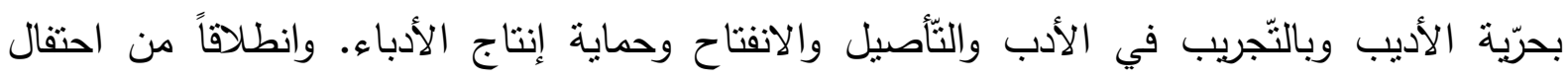

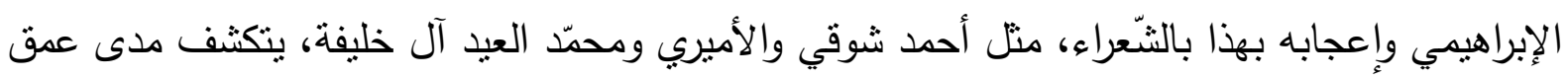

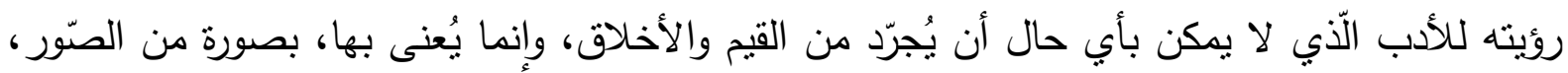

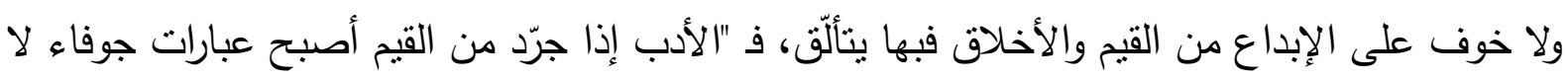

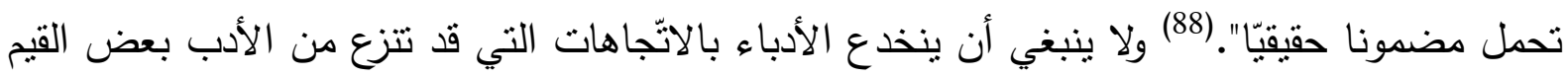
والأخلاق وتتزل به إلى مستتقع الثّهوات وحضيض الإباحيّات بدعوى الفنّ للفنّ.

) خاتمة

إنَّ قِراءَة الثُّيخ الإبراهيميّ لشعر شوقي لهي قراءة محيطة بشتى عناصر (النّّاصل الأدبيّ)، بَذْءًا

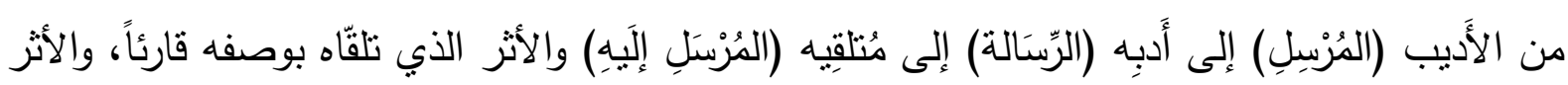

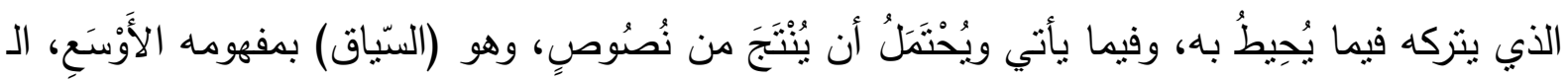

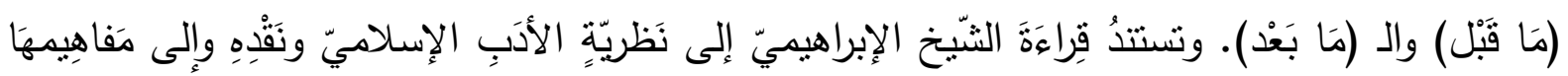

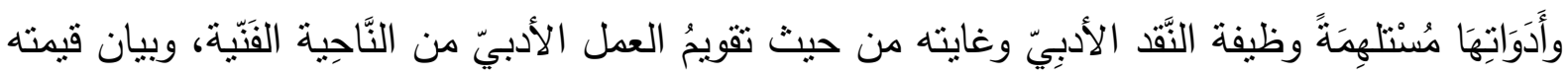




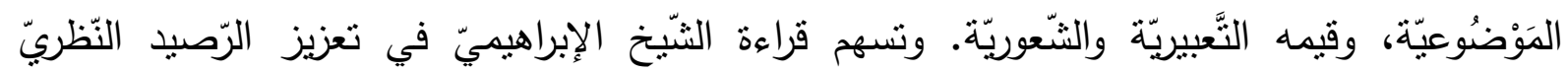

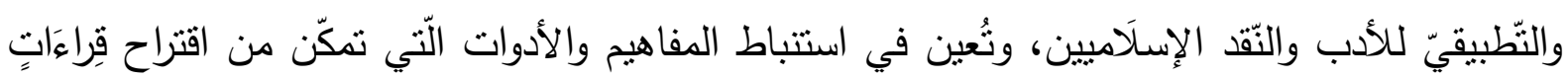

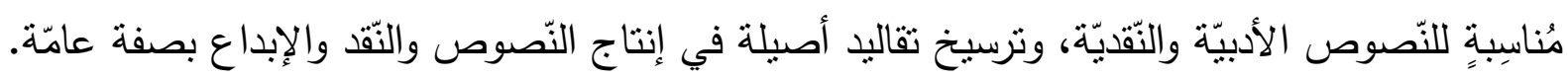

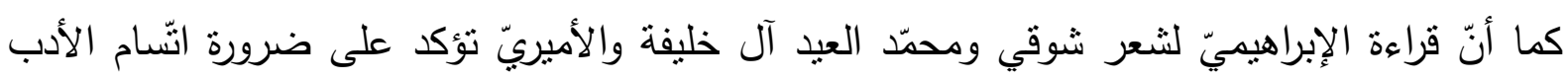

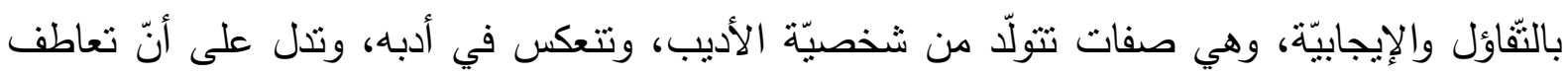

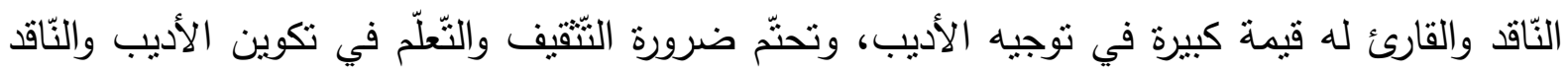

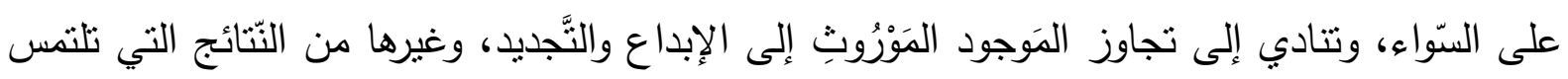

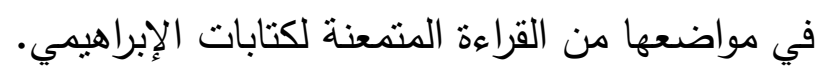

1- عبد الملك بومنجل: "النثر الفني عند البشير الإبراهيمي"، بيت الحكمة، العلمة، الجزائر ، ط: 1، 2009، ص: 84 2- المرجع السابق، ص: 34

3- محمد طالب الإبراهيمي: "آثار محمد البشير الإبراهيمي"، ج: 4، دار الغرب الإسلامي، بيروت، ط: 1، 1997، ص: 67 4- المرجع السابق، ص: 68 5- المرجع السابق، ص: 170 6- رابح بن خوية: "نظرات الإبراهيمي في الأدب والنقد؛ قراعته لشعر أحمد شوقي نموذجا"، مجلة الآداب واللغات، كلية الآداب

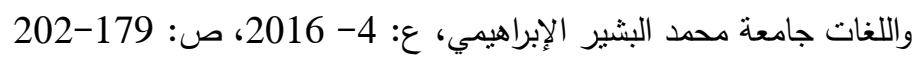

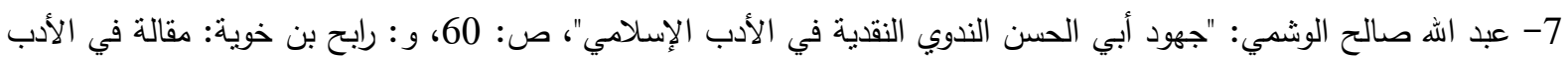

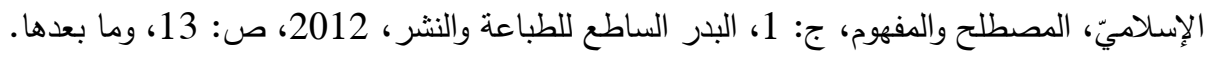
8- سيد قطب: "في التاريخ فكرة ومنهاج"، ص: جالح: 28 9- مأمون فريز جرار : "خصائص القصة الإسلامية"، ص: صن: 27 10- "الدين في شعر شوقي"، مجلة الثنبان المسلمين، عددي مارس/أبريل 1955

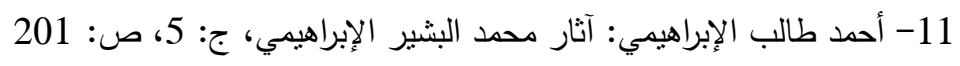

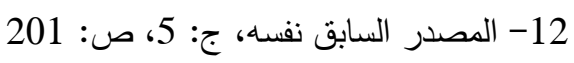
13- المصدر نفسه، ج: 5، ص: ص: ج: 202 14- المصدر نفسه، ج: 5، ص: ص: 5: 202 15- المصدر السابق نفسه، ج: 5، صن: صن: 202 16- المصدر نفسه، ج: 5، صد: صن: 203 17- المصدر نفسه، ج: 5، صن: المد: 204

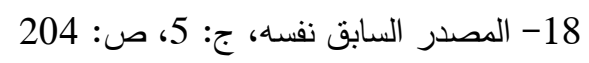
19- المصدر السابق نفسه، ج: 5، صن: ص: 20- المصدر السابق نفسه، ج: 5، ص: صن: 205

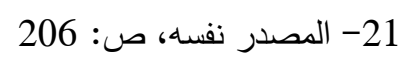
22- المصدر نفسه، الصفحة نفسها. 
23- المصدر السابق نفسه، ص: 206

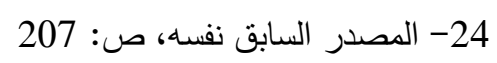

25- المصدر نفسه، الصفحة نفسها.

26- المصدر نفسه، ج: 5، ص: ص: 27 209

27- المصدر السابق نفسه، ج: 1ل 1، ص: ص: 28 106

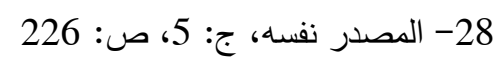

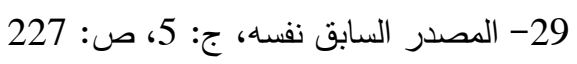

30- الدصدر نفسه، ج: 5، صد: صن: 228

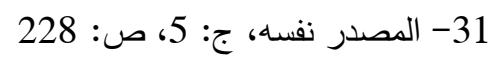

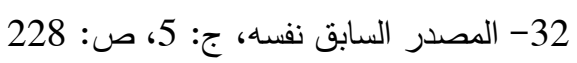

33- المصدر نفسه، ج: 5، صدن: ص: 228

34- الدصدر نفسه، ج: 5، صن: صن: 229

35- سيد قطب: "النق الأدبي أصوله ومناهجه"، دار الثروق، القاهرة، ط: 8، 1424هـ -329-2003م، ص: صن: 8

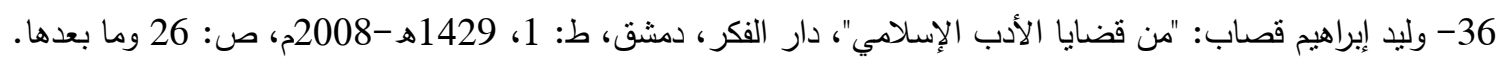

37- 37 الآثار، ج: 1-38

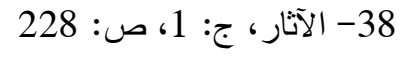

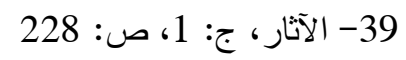

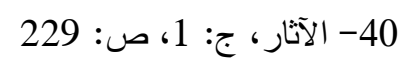

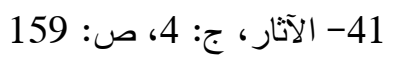

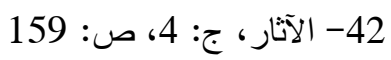

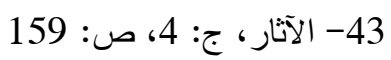

44- الآتار، ج: 4- 4الار، ج: ص، صن: 160

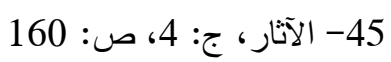

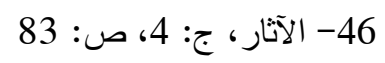

47- الآثار، ج: 4الثار، ج: 4، ص: 48 83

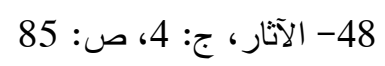

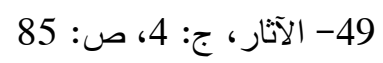

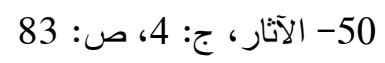

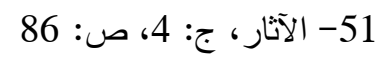

52- الآثار، ج: 4، صن ص:

53- ابن قتنية: "الثعر والثعراء"، ص: صن: 104

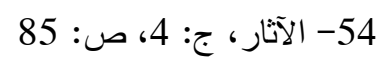

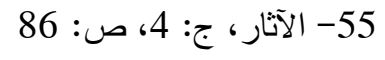

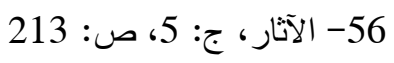

57- الآثار ، ج: 56، ص: 5: 5: 5: 213

58- المصدر السابق نفسه، ص:

59- المصدر السابق نفسه، ص: 208 
60- المصدر نفسه، ص: 229

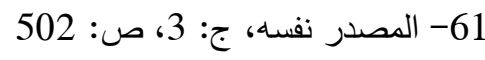

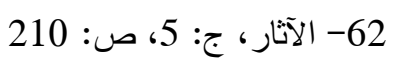

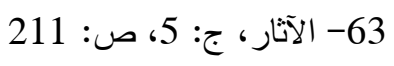

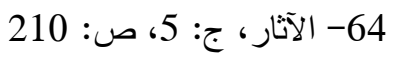

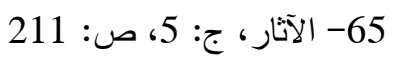

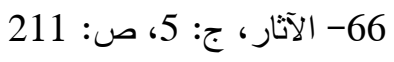

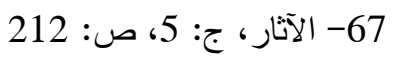

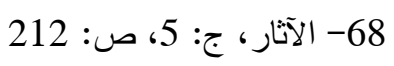

69- الآثار ، ج: 5، صن: ص: 213

70- الآثار ، ج: 5، صنار، ص، ص: 211

71- الآثار، ج: 5، صن ص: 5، صن: 211

72- الآثار ، ج: 5، صن:

73- الآثار، ج: 5، صن: صن: 212

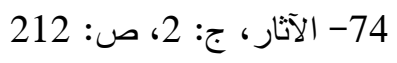

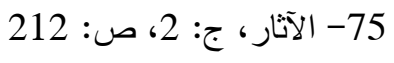

76- الآثار، ج: 25، صالتار، ص، صن: 212

77- الآثار ، ج: 5، ص: ص: 216 213 213

78- الآثار، ج: 5، صن: صن: 213

79- الآثار ، ج: 5، ص: ص: 5، صن: 213

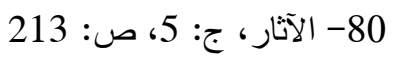

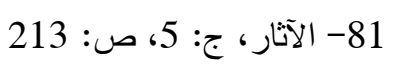

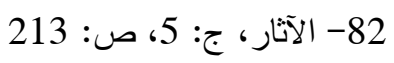

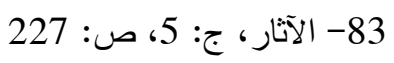

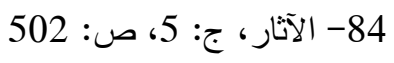

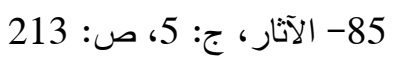

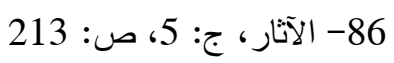

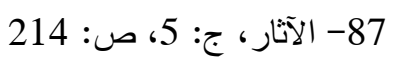

88- سيد قطب: "في التاريخ فكرة ومنهاج"، ص:

- الوشمي، عبد الله صالح: "جهود أبي الحسن النّدوي النقدية في الأدب الإسلامي"، مكتبة الرّشّد، الرّيّاض، ط: 1، 1426هـ 2005

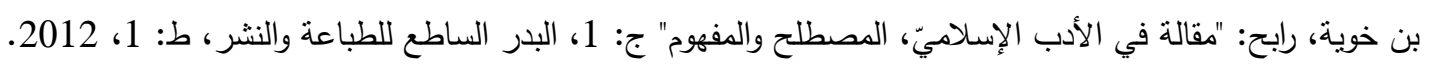

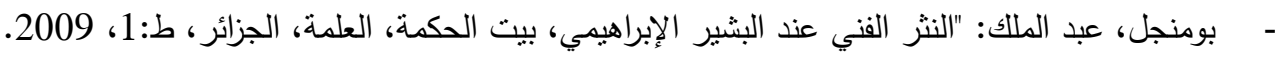

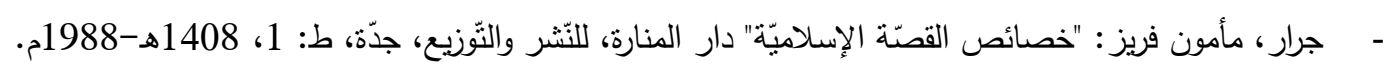

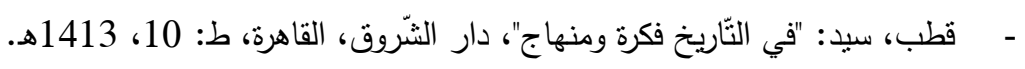

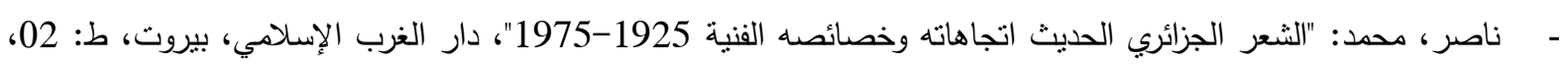
.2006 